Utah State University

DigitalCommons@USU

All U.S. Government Documents (Utah Regional U.S. Government Documents (Utah Regional Depository)

1981

\title{
Hydrology of the Ferron Sandstone Aquifer and Effects of Proposed Surface-Coal Mining in Castle Valley, Utah
}

\author{
Gregory C. Lines \\ Daniel J. Morrissey \\ Thomas A. Ryer \\ Richard H. Fuller \\ U.S. Geological Survey
}

Follow this and additional works at: https://digitalcommons.usu.edu/govdocs

Part of the Geology Commons

\footnotetext{
Recommended Citation

https://digitalcommons.usu.edu/govdocs/567

This Report is brought to you for free and open access by the U.S. Government Documents (Utah Regional Depository) at DigitalCommons@USU. It has been accepted for inclusion in All U.S. Government Documents (Utah Regional Depository) by an authorized administrator of DigitalCommons@USU. For more information, please contact digitalcommons@usu.edu.
}

Lines, Gregory C.; Morrissey, Daniel J.; Ryer, Thomas A.; Fuller, Richard H.; and U.S. Geological Survey, "Hydrology of the Ferron Sandstone Aquifer and Effects of Proposed Surface-Coal Mining in Castle Valley, Utah" (1981). All U.S. Government Documents (Utah Regional Depository). Paper 567.

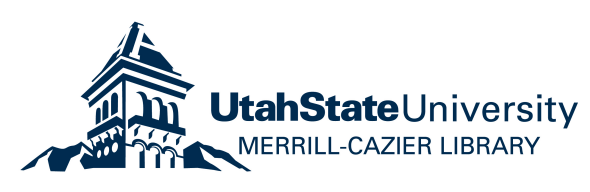



HYDROLOGY OF THE FERRON SANDSTONE AQUIFER AND EFFECTS
OF PROPOSED SURFACE-COAL MINING IN CASTLE VALLEY, UTAB

By Gregory C. Lines and Daniel J. Morrissey

With a section on Stratigraphy by Thomas A. Ryer and

a section on Leach1ng of Overburden by Rdibard $\mathrm{B}$. Fuller

v.s. GEOLOGICAL, SURVEY

OPEN-FILE REPORT 81-535

Prepared in cooperation with the
U.S. BUREAU OF LAND MANAGEMENT

Salt Lake C1ty, Utah
\[ 1982 \]

$2+3$

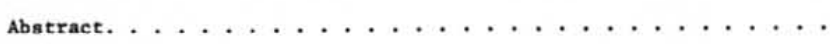

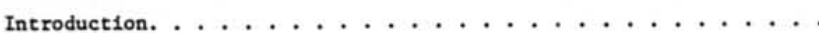

Problem and objectives ...............

Methods of 1nvestigation ...............

Previous 1nvestigations $\ldots \ldots \ldots \ldots \ldots \ldots$

Acknowledgments. . . . . . . . . . . . .

We11-, spring-, and site-numbering system . . . . . . .

Strat1graphy by Thomas A. Ryer. . . . . . . . . . Ferron sandstone aquifer. . . . . . . . . . . .

Aquifer characteristics. ...............

Thickness . . . . . . . . . . .

Hydraulic conductivity. . . . . . . . . . .

Transmissivity ................

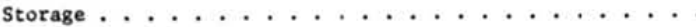

Potent1ometric surfaces. . . . . . . . . . .

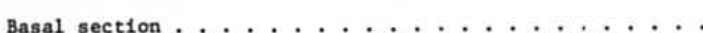

Upper $\operatorname{section} \ldots \ldots \ldots \ldots \ldots \ldots \ldots \ldots$

Adjacent vater-bearing zones. . . . . . . . . .

Water-1evel changes . . . . . . . . . . .

Movement and age of water. . . . . . . . .

Recharge and discharge . . . . . . . . . .

Subsurface inflow ................

Precipitation on outcrop area ..........

Leakage . . . . . . . . . . . . . 
Need for future study $\ldots \ldots \ldots \ldots \ldots \ldots \ldots$

Ferron sandstone aquifer--Continued

Need for future study $\ldots \ldots \ldots \ldots \ldots \ldots$

Recharge and discharge--Continued

Transpiration of phreatophytes .......... 63

springs and seeps . . . . . . . . . . . . 65

Well discharges ................ 66

Mine devatering $\ldots \ldots \ldots \ldots \ldots \ldots \ldots$

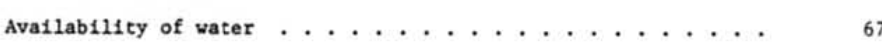

Quallty of vater ...................... 68

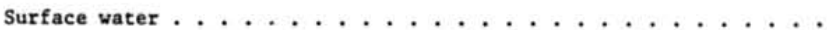

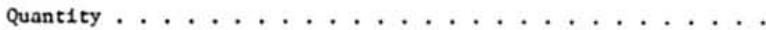

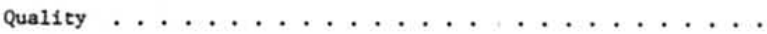

Inorganic dissolved solidis. . . . . . . . . . .

suspended sediment. . . . . . . . . . . . . .

Benth1c invertebrates. . . . . . . . . . . .

Computer nodel. . . . . . . . . . . . . . .

Assumptions and accuracy $\ldots \ldots \ldots \ldots$

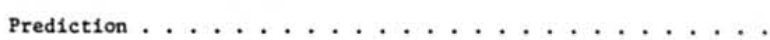

Effects of proposed surface mining ...........

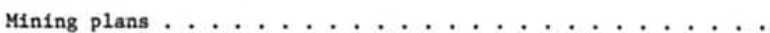

Mine dewatering. . . . . . . . . . . .

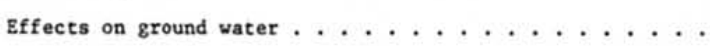

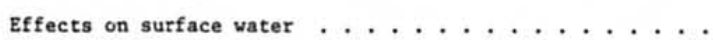

Leaching of overburden by Richard H. Fuller. . . . . . . .

Erosion of overburden. . . . . . . . . . .

(1)

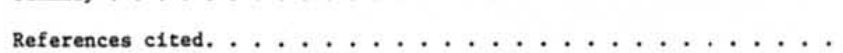

illustrations

Figure 1. Map of Utah showing the study area .........

2. Map showing location of selected wells, şrings, and test holes in and near Castle Valley, Utah,

where ground-water information is ava1lable, $1980 \ldots$.

3. D1agram showing the we11-, spring-, and sitenumbering system used in Utah ...........

4. Map showing the thickness of the Ferron Sandstone Member of the Mancos Shale in Castle Valley, Utah . . . .

5. Map showlng the altitude of the top of the Perron Sandstone Member of the Mancos Shale in Castle valley, vtah. . . . . . . . . . . . . .

6. Photograph showing the outcrop of the Ferron Sandstone Member of the Mancos Shale along Quitchupah Creek

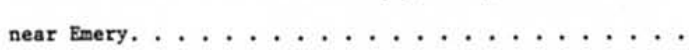

7. Photograph showing the outcrop of the Washboard unit of Cotter (1975a) of the Ferron Sandstone Member of the Mancos Sha1e along U.S. H1ghway 6 southeast of

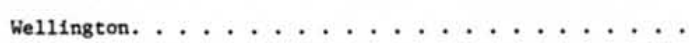


F1gure 8. D1agramatic southwest-northeast sect1on showing stratigraphic relationships of the various units of the Ferron Sandstone Member and the Tununk and Blue Gate Mesbers of the Mancos Shale in Castle

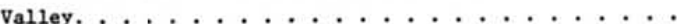

9-13. Maps of the Enery area showing:

9. Geology .................. 33

10. Transmissivity of the Ferron sandstone aquifer. . .

11. Potentiometric surface of the basal section of the Ferron sandstone aquifer, $1979 \ldots \ldots$. . . .

12. Potentiometric surface of the upper section of the Ferron sandstone aquifer, $1979 \ldots \ldots$. . .

13. Configuration of the water table in rocks that overlie the Ferron sandstone aquifer, $1979 \ldots \ldots$

14. Hydrographs showing water-level changes in four wells that tap the Ferron sandstone aquifar in the Emery

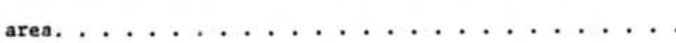

15. Diagramatic section showing sources of recharge to and discharge from the Ferron sandstone aquifer in the Emery area, 1979. . . . . . . . . . . . . .

16. Photograph showing salt on the barren shale slopes of the Tununk Member of the Mancos Shale where ground

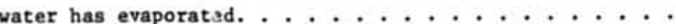


Figure 23. Map of the Emery area showing the variable grid used In the three-dimensional digital-computer model and the predicted drawdown of the potentiometric suriace of the upper section of the Ferron sandstone aquifer around the proposed surface mine after 15 years of

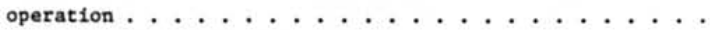

24. Photograph showing area of proposed surface mine along Christiansen Wash . . . . . . . . . . .

25. Photograph showing sparsely vegetated surface of the Blue Gate Member of the Mancos Shale that is typical of area where proposed surface mining will terminate. . . TABLES

Table 1. Laboratory determinations of porosity, hydraulic conductivity, and grain size of rock samples from the Ferron Sandstone Member of the Mancos Shale . . . . . . .

2. Summary of aquifer tests conducted on the Ferron sandstone aquifer in the Emery area, 1978-79. . . . . . .

3. Description of samples from the Ferron Sandstone and Blue Gate Members of the Mancos Shale that were used in equilibration experiments. . . . . . . . . . .

4. Chemical analyses of leachate after equilibration with typical spoil material from the Ferron Sandstone and Blue Gate Members of the Mancos Shale . . . . . . . . . .

5. Records of selected wells, test holes, and springs in the Castle Valley area. . . . . . . . . . . . . .

Table 6. Chemical analyses of water from vells, test holes, springs, and the Emery Mine.............

7. Benthic 1nvertebrates collected from Christiansen Wash and Qu1tchupah Creek in the Emery area, 1978-79. . . . . . . 
Most numbers are given in this report in inch-pound units. For those readers who may prefer to use metric un1ts, the conversion factors for the terms used in this report are 1isted belou. Multiply the inch-pound unit by the factor to obtain the metric equivalent.

Inch-pound

$$
\text { Unit }
$$

Abbreviat1on

\section{(multiply)}

Acre

Acre-foot

Acre-foot per

square mile

Cubic foot per

second

Foot

Foot per mile

Gallon per minute

Inch

M1:

Square foot

Square mile

Ton (short,

2,000 pounds)
Metric unit

(to obta1n)

Square hectometer

Cub1c hectometer

Cubic meter per

square k1lometer

Cubic meter per

second

Meter

0.3048

0.1894

0.06309

25.40

2.540

1.609

0.0920

2.590

0.9072

Chemical concentration and water teaperature are given in metric units. Chemical concentration is given in milligrams per 11ter (mg/L) or micrograms per 11ter (ug/L). Milligrams per 1iter is a unit expressing the concentration of chemical constituents in solution as veight (milligrams) of solute per unit volume (11ter) of water. One thousand m1crograms per 11ter 1s equivalent to one milligram per 11ter. For concentrations less than $7,000 \mathrm{mg} / \mathrm{L}$, the numerical value is about the same as for concentrations in parts per million.

Water temperature is given in degrees Celsius $\left({ }^{\circ} \mathrm{C}\right)$, which can be converted to degrees Fahrenhe1t $\left({ }^{\circ} \mathrm{F}\right)$ by the following equation: ${ }^{\circ} \mathrm{F}=1.8\left({ }^{\circ} \mathrm{C}\right)+32$.

Radioactive concentration is given in picocuries per 11ter, which is a unit quantity of any radioactive material in which $3.7 \times 10^{-2}$ disintegrations occur per second (picocurie) per unit volume (11ter) of water.

MATIONAL GEODETIC VERTICAL DATUM OF 1929

National Geodetic Vertical Datum of 1929 is used in this report. It is a geodetic datum derived from a general adjustment of the first-order level nets of both the United States and Canada, formerly called "Mean Sea Leve1". 
HYDROLOCY OF THE FERRON SANDSTONE AQUIFER AND EFFECTS

OF PROPOSED SURFACE-COAL MINING IN CASTLE VALLEY, UTAH

By Gregory C. Lines and Daniel J. Morrissey

ABSTRACT

Coal in the Ferron Sandstone Member of the Mancos Shale of Cretaceous age has traditionally been alned by underground techniques in the Emery Coal Field In the southern end of Castle Valley in east-central Utah. However, approximately 99 million tons are recoverable by surface mioing. Ground water in the Ferron is the sole source of supply for the town of Emery, but the aquifer is essentially untapped outside the Emery area.

The Ferron Sandstone Member crops out along the eastern edge of Cast1e Valley and generally $\mathrm{d} 1 \mathrm{ps} 2^{\circ}$ to $10^{\circ}$ to the northwest beneath the surface. Sandstones in the Ferron are enclosed between relatively 1mpermeable shale in the Tununk and Blue Gate Members of the Mancos Shale. Along the outcrop, the Ferron ranges in th1ckness from about 80 feet in the northern part of Castle Valley to 850 feet in the southern part. The Ferron also generally thickens in the subsurface downdip from the outcrop. Records from vells and test holes Indicate that the full th1ckness of the Ferron is saturated with vater in most areas downdip from the outcrop area.

Tests in the Emery area Indicate that transaissivity of the Ferron sandstone aquifer ranges from about $20 \mathrm{C}$ to 700 feet squared per day where the Ferron is fully saturated. Aquifer transmissivity is greatest near the Paradise ValleyJoes Valley fault system where permeability has been increased by fracturing. Storage coefficient ranges from about $10^{-6}$ to $10^{-3}$ where the Ferron sandstone aquifer is confined and probably averages $5 \times 10^{-2}$ where it is urconfined.
The largest source of recharge to the Ferron sandstone aquifer in the Emery area is subsurface inflow from the Wasatch Plateau to the west (about 2.4 cubic feet per second during 1979), most of which moves laterally through the more permeable zone along the Paradise Valley-Joes Valley fault system. Little water is recharged to the aquifer by the 8 inches of nornal annual precipitation on the outcrop area. Natural discharge fron the aquifer is mainly leakage to alluvium along streans in the outcrop area and leakage to the enclosing shales in the Tununk and Blue Gate Members. Discharge from vells that tap the Ferron in Castle Valley averaged about 0.3 cubic foot per second during 1979. D1scharge from the underground Enery Mine averaged about 0.7 cubic foot per second during 1979 and was the largest manmade discharge from the aquifer.

The 1argest quantities of water are avallable from the Ferron sandstone aquifer within about 2 miles of the Paradise Valley-Joes Valley fault system in the Emery area. Most wells in this area naturally flow at the land surface at rates less than 100 gallons per minute, but yields could be increased by pumping. Wells that fully penetrate the aquifer in this area could be expected to produce 100 to 500 gallons per minute if pumped. In the northern two-thirds of Castle Valley the Ferron would probably not yield sore than 10 gallons per minute to individual vells. 
The concentration of dissolved solids in water from the Ferron sandstone aquifer in the Emery area Increases eastward from the Paradise Valley-Joes Valley fault systim toward the outcrop area of the Ferron, in the general direstion of grornd-water muvement. Dissolved-solids concentrations also 1ucrease upward in the aquifer in areas downdip from the outcrop. In the Emery area, dissolved-solids concentrations in water from the Ferron ranged from less than 500 to moze than $8,000 \mathrm{mg} / \mathrm{L}$ (milligrams per 11ter) during 1979. Deterioration in water quality in the Emery area usually is due to increased concentrations of dissolved sodium and sulfate. In the northern two-thirds of Castle Vailey, dissolved-solids concentrations usually exceed $3,000 \mathrm{mg} / \mathrm{L}$, and several test holes and gas wells have yielded water from the Ferron with chloride concentrations greater than $10,000 \mathrm{mg} / \mathrm{L}$ and dissolvedsolids concentrations greater than $20,000 \mathrm{mg} / \mathrm{L}$.

Qu1tchupah Creek, near the underground Emery Mine, and Christ1ansen Wash, downstream from a proposed surface-coal mine in the Emery area, were gaged during the 1979 vater year, and stream discharges averaged 6.7 and 2.8 cubic feet per second. There were large seasonal variations in water quality in both strea-s during the water year. Observed dissolved-solids concentrations at the gaging station on Quitchupah Creek ranged from 695 to $3,960 \mathrm{mg} / \mathrm{L}$, and observed suspended-sediment concentrations ranged from 111 to $27,000 \mathrm{mg} / \mathrm{L}$. At the station on Christiansen Wash, observed dissolvedsolids concentrations ranged from 582 to $4,470 \mathrm{mg} / \mathrm{L}$ and suspended-sediment corcentrations ranged from 3 to $4,870 \mathrm{mg} / \mathrm{L}$.
A three-dimensional digital-computer model was used to simulate groundwater flow in the Ferron sandstone aquifer in the Emery area. The model also was used to predict the effects of dewatering of a proposed surface mine on aq. Ifer potent1ometric surfaces and the base flow of streams. The computer model was calibrated with water-level data collected during 1979. Mainly because it was not possible to verify the model with historic data for aquifer response to manmade discharges, predictions made with the model are considered to be semig̣vantitative.

Discharge from the proposed surface mine is predicted to average about 0.3 cubic foot per second during the 15 years of mine operation. Devatering of the mine would affect the potentiometric surfaces of all sections of the Ferron sandstone aquifer, but the greatest iffects would be in the upper section. Drawdowas in the potentiometric surface of the

upper section of the aquifer greater than 5 feet are predicted to extend about 2 miles from the surface mine after 15 years of operation. Mine dewatering would also induce downward leakage of water into the Ferron from shale in the Blue Gate Member, and this could sause a deterioration in water quality in the upper section of the aquifer in some areas. West of the surface mine, however, the quality of water in the upper section of the aquifer might improve as the amount of saline water leaking downward from the Blue Gate Member would be small in comparison to the amount of water that would move laterally through the aquifer from the west. 
Modeling results Indicate that, except for Christiansen Wash, the devatering of the proposed surface mine would not affect the base flow of streams. If vater fron the mine were discharged Into Christiansen wash, the base flow would Increase accordingly. The dissolved-solids concentration of vater in Christiansen Wash also would be increased, at least during some periods, if mine water were discharged into the stream.

Laboratory experinents indicate that if only precipitation were allowed to infiltrate mine spo11, water in the spoil would be of better quality than most ground water in the mine area and about the same quality as water in Christiansen wash. Hovever, the management of the spoil to reduce surfacewater infiltration and spoil placement so that pyritic material is mixed with calcareous material would minimize the deterioration of water quality in Chrenciansen Wash.

Sediment loads of streams downstream from the mine would not increase significantly if reclaimed slopes were graded to the least possible angle, If revegetation vere prompt so as to stabilize the stockpiled topso1l and backfilled overburden, if runoff were channeled from the disturbed mine area through sediment ponds, and if Christiansen Wash were permarently diverted around the mine area. The long-term sediment yleld from the disturbed area could actually decrease if vegetative cover were improved from premining conditions and if sediment ponds were properly maintained.

\section{INTRODUCTION}

Problem and objectives

Coal traditionally has been recovered by underground-mining techniques in the Emery Coal Field in the southern end of Castle Valley in east-central Utah. (See f1gs. 1 and 2.) The coal is in a number of seams in the Ferron Sandstone

F1gure 1 (caption on next page) wear here

Member of the Mancos Shale of Cretaceous age. The total coal resource of the area has been estimated at 2.06 b111ion tons (Doelling, 1972, p. 437). Of this total, approximately 99 million tons is recoverable by surface-mining techniques (Affolter and others, 1979, p. 1), and plans have been made for a surface mine in the area.

Ground water from the Ferron sandstone aquifer is the sole source of supply for the town of Emery (population about 370). Water from the Ferron also is used for stock vatering, for a small amount of irrigation, and for a coal-washing plant in the southern end of the Emery Coal Field. The aquifer is essentially unused in the northern two-thirds of Castle Valley.

Water supplies throughout Castle Valley are being stressed by increased population that is associated with the increase in coal production from not only the Emery Coal Field but also nearby coal fields in the Wasatch Plateau and Book cliffs. In addition to three existing coal-fired powerplants now in operation in Castle Valley, a coal-gasification plant has been proposed near Emery. The gasIf 1 cation plant reportedly will require 5 million tons of coal and 10,000 acre-feet of water per year. 


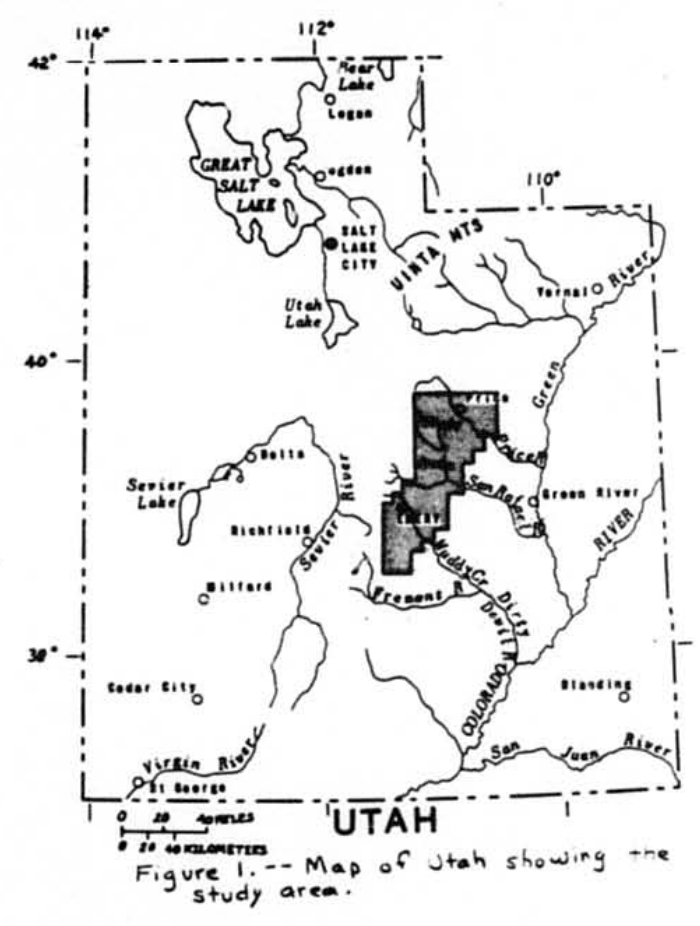

In order to anticipate the effects of 1ncreased coal mining and related energy developments on the hydrology of the area, the U.s. Geological Survey In cooperation with the U.S. Bureau of Land Management conducted a study from October 1977 through September 1980. The obfectives of the study were to determine: (1) the aquifer characteristics, recharge-discharge relationships, and the quantity and quality of water that is avallable from the Ferron sandstone aquifer in Castle Valley; (2) the effects of proposed surface-coal mining and associated mine dewatering on existing wells and springs, on the base flow and quality of water in streams, and on the quality of water in the Ferron sandstone aquifer; and (3) the uffects of solution and erosion of stockpiled overburden at the proposed surface mine on the quality of surface water and stream aquatic 11fe.

\section{Methods of investigation}

Fieldwork for the study was started in October 1977 and concluded in January 1980. Dusing this time a complete well inventory was made in Castle Valley. We1ls, test holes, and springs in Castle Valley where ground-water data are avallable are shown in figure 2. As part of the study, 16 observation wells were constructed

\section{Figure 2 (caption on next page) near here}

from a number of sources, including abandoned seismic-test holes and coal-test holes that were drilled by the Bureau of Land Management and the Geological Survey. In addition, four test holes vere drilled and tested with expandable packers in the Emery area.

In the Emery area, the water 1 evel or shut-1n water pressures were measured monthly at 18 vells. In addition, water-level data vere obtained at about 40 other sites during the course of the study. 
Figure 2.-Map showing location of selected wells, springs, and test holes In and near Castle Valley, Utah, where ground-water information 1s aval1able, 1980.
Iristantaneous discharge of the pump that dewaters the underground Emery Mine was measured three times, and total discharge was calculated from records of pumping time supplied by Consolidation Coal Co. Withdrawals frow the Emery municipal well were obtained from meter records supplied by town offic1als, and the dischacge of other vells were measured.

Aquifer tests were conducted at nine locations to provide information on the hydraulic properties of the Ferron sandstone aquifer. Four of tie tests 1nvolved a pumping well and at least one observation well, and the other tests were conducted at flowing vells or test holes.

Water samples for determination of dissoived inorganic chemic: 1 constituents were collected from about 60 wells, test holes, and springs in Castle Valley. Water samples were also collected from seepage areas in the Emery Mine. In an attempt to determine the age of water in the Ferron sandstone aquifer, carbon-14 and tritium determinations were made for vater collected in the Emery Mine and from selected wells.

As part of the hydrologic monitoring in coal areas by the Geological Survey, stream-gaging stations vere installed on Christiansen Wash and Quitchupah Creek near the Emery Mine and the proposed surface mine. The stations were operat1onal by August 1978. Water samples vere collected monthly for determination of mafor 1norganic chemical constituents and quarterly for determinations of suspended-sediment concentration, nutrients, trace metals, and benthic invertebrates. To supplement the scheduled quarterly sampling, additional sediment samples were collected during floods and during periods of high runoff in the spring. 
Laboratory experiments vere conducted to determine which minerals could be leached from the rocks that overlie the strippable coal at the proposed surface mine. The rock samples were obtained from cores collected at test holes drilled for the Bureau of Land Management. Other laboratory work 1ncluded determinations of porosity, horizontal and vertical hydraulic conductivity, and grain size of core samples that were typical of rocks in the Emery Coal Field.

A three-dimensional digital-computer model of the Ferron sandstone aquifer was developed to evaluate the effects of dewatering the proposed surface mine on the potent1ometric surface of the aquifer and the base flow of streams.

$$
\text { Previous investigations }
$$

Lupton (1916) conducted a comprehensive study of the geology and coal resources of Castle Valley. Additional geologic information on the Emery Coal Field was presented by Doelling (1972). Information on the stratigraphy and depositional history of the Ferron Sandstone Member was presented by Kat1ch (1951, 1953, and 1954), Davis (1954), Hale (1972), and Cotter (1975a, b and 1976).

Ground water in bedrock aquifers in the Colorado Plateau, Including the Ferron sandstone aquifer, was described by Feltis (1966). During the 1970's, several hydrologic studies were conducted in Castle Valley. The quality of surface water in the Price River and Dirty Devil River basins was described by Mundorff (1972 and 1979). Hydrologic conditions in the Wasatch Plateau and Book Cliffs Coal F1elds were described by Waddell, Contratto, Sumsion, and Butler (1979). Some hydrologic data from the Emery area are 1ncluded in reports by Wadde11, Vickers, Upton, and Contratto (1978) and Sumsion (1979). Reclamation of possible surface-mine lands in the Emery Coal Field was described by Geoscientific Systems and Consulting (1979).

\section{Acknowledgments}

The uriters wish to express their appreciation to Consolidation Coal Co., Hidden Valley Coal Co., and Western States Minerals Co. for supplying geologic and hydrologic information from their testing and monitoring programs and for allowing access to their property for test drilling and other studies. We are grateful to the townspeople of Emery for supplying records of water use and for allowing an aquifer test to be conducted on the municipal well. Thanks are also given to the many landowiers in Castle Valley who granted permission to drill test holes and to sample and test wells. 
Wel1-, spring-, and site-numbering system

The system of numbering vells and springs in Utah is based on the cadastral land-survey system of the U.S. Government. The number, in addition to designating the vell or spring, describes 1 ts position in the land net. By the land-survey systev., the State is divided into four quadrants by the Salt Lake base line and meridian, and these quadrants are designated by the uppercase letters A, B, $C$, and $D$, Indicating the northeast, northwest, southwest, and southeast quadrants, respectively. Numbers designating the township and range (in that order) follow the quadrant letter, and all three are enclosed in parentheses. The number after the parentheses indicates the section, and is followed by three letters indicating the quarter section, the quarter-quarter section, and the quarterquarter-quarter section-generally 10 acres_/; the letters a, b, c, and d

Although the basic land unit, the section, is theoretically $1 \mathrm{mi}^{2}$, many sections are 1rregular. Such sections are subdivided into 10-acre tracts, generally beginning at the southeast corner, and the surplus or shortage is taken up in the tracts alring the north and vest sides of the section.

Indicate, respectively, the northeast, northwest, southwest, and southeast

quarters of each subdivision. The number after the letters is the serial number of the well or spring with the 10-acre tract; the letter " $\mathrm{s}$ " preceding the serial number denotes a spring. If a vell or spring cannot be located within a 10-acre tract, one or two location letters are used and the serial number is omitted. Thus (D-22-6)23adb-1 designates the first well constructed or visited in the NWhSEkE⿰冫欠 $\sec 23$, T. 22 S., R. 6 E. Other sites where hydrologic data were collected are numbered in the same manner, but three letters are used after the section number and no serial number is used. The numbering system is 11luetrated in figure 3.

Figure 3 (caption on next page) near here
Sections within a tamshio
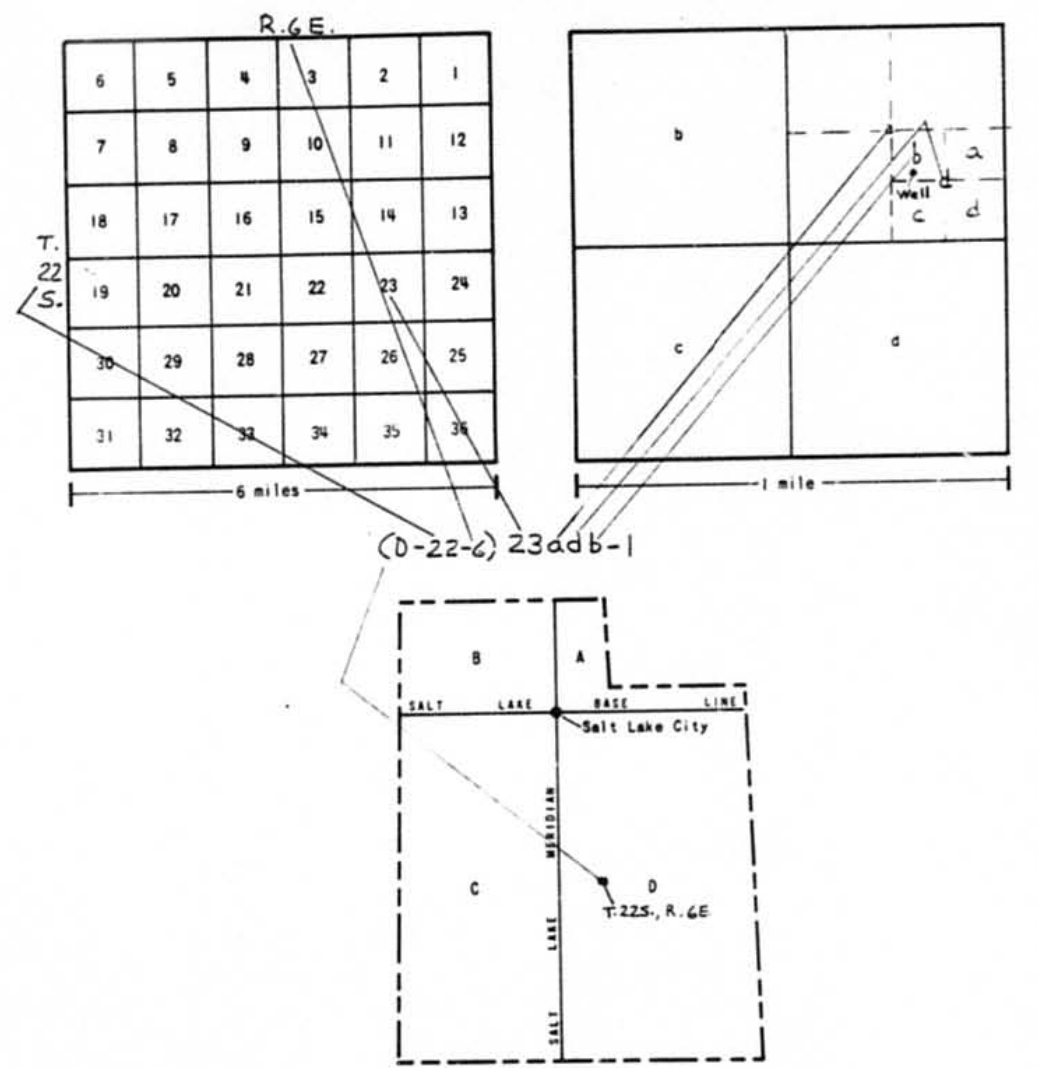
Figure 3.-- Well-, spring-, and site-numbering
system used in Utah. 
The Ferron Sandstone Menber of the Mancos Shale, the coal-bearing unit in the Emery Coal Field, is exposed in a series of prominent cliffs in the southern part of Castle Valley. The escarpment produced by the Ferron defines the eastern 1imit of Castle Valley. The Ferron cliffs attain their maximum development between the town of Moore and the southern end of Castle Valley. The thickness of the Ferron generally increases southward from about 300 feet near Moore to about 850 feet near the southern end of Castle Valley. (See f1g. 4.) The Ferron dips $2^{\circ}$ to $10^{\circ}$ to the northwest beneath the surface of Castle Valley. The altitude of the top of the Ferron is shown in figure 5 .

Figures 4 and 5 (captions on next page) near here

In the area between Woore and the southern end of Castle Valley, the Ferron consists of wassive beds of very fine to medium-grained, delta-front sandstone, prodelta mudstones, and a wide variety of delta-plain rock types (mainly carbonaceous shale, coal, mudstons, siltstone, and thin-bedded, rippled, very fine grained sandstone). The Ferron outcrop along Quitchupah Creek near Emery 1s shown in figure 6.

Figure 6 (caption on next page) near here

Figure 4.-Map showing the thickness of the Ferron Sandstone Member of the Mancos Shale in Castle Valley, Ucah.

Figure 5.--Map showing the altitude of the top of the Ferron Sandstone Member of the Mancos Shale in Castle Valley, Utah.

Figure 6.--Outcrop of the Ferron Sandstone Member of the Mancos Shale along Quitchupah Creek neaz Emery. View facing north. 


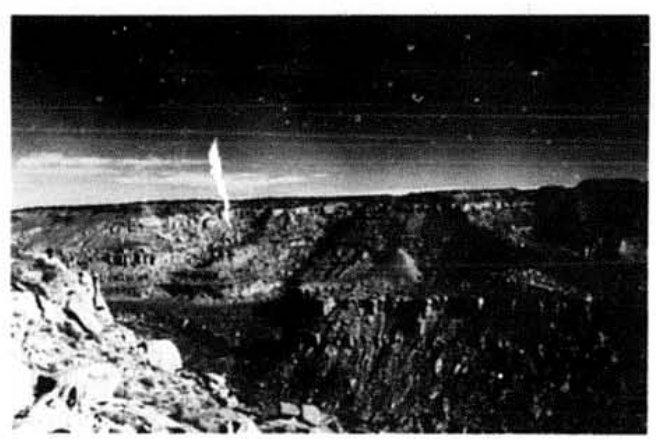

North of Moore, the Ferron escarpment gradually becones mo:e subdued unt11, at the latitude of Cast1e Dale, the Ferron is represented by a pair of units

of very sine grained, silty sandstone each about 50 feet thick. The upper unit of this pair, shown in figure 7 , crops out continuously along the east side of

Figure 7 (caption on next page) near here

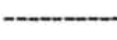

Castle Valley from about Emery to as far as Wellington at the northern end of Castle Valley. The lower unit pinches out northward near the town of Cleveland. One or more ledge-forming units of very fine grained sandstone and sandy siltctone occur at the stratigraphic level of the Ferron between Wellington and the Utah-Colorado State 1ine, and these are mapped collectively as Ferron Sandstone Member on the geologic map of Utah (Stokes, 1964).

Figure 6.--The outcrop of the Ferron Sandstone Member of the Mancos Shale along Quitchupah Creek near Emery. 


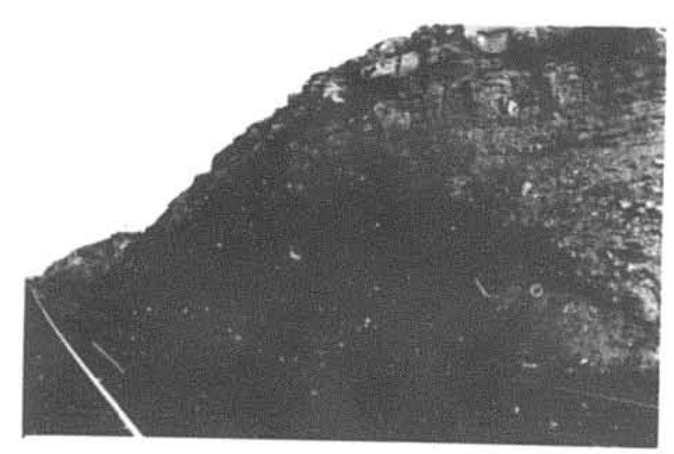

F1gure 7.--Outerop of the Washboard Unit of Cotter (1975a) of the Ferron Sandstone Member of the Mancos Shale along U.S. H1ghway 5 southeast of We11ington.

The first, and still the most comprehensive study of the geology and mineral resources of the Perron Sandstone Member was conducted by Lupton (1916). Minor modification and updating of Lupton's coal-resource calculations vere made by Doelling (1972). Lupton (1916, p. 31) named the Ferron Sandstone Member for exposures "in the vicinity of Ferron and Emery." Though he c1ted no type locality for the nember, a section along Ivie Creek, about 8 miles south of Emery, was presented as representative. It is clear from Lupton's description of the stratigraphy of the Fer:on (1916, p. 31-33) that he consicered che pair of very fine grained sandstones in the northern part of Castle Valley to be a northward extension of the thicker, coal-bearing sequence of strata exposed near Emery. Later work by Katich $(1951,1953$, and 1954), Davis (1954), and Cotter ( -975 a h and 1976) demonstrate that this is not the case. The pair of Ferron units of northern Castle Valley are about 100 feet stratigraphically lower than the lowest delta-front sandstone of the Ferron Sandstone Member that crops out south of Emery, and they pinch out toward the south into the marine shale of the Tununk Member of the Mancos. (See fig. 8.) The two Ferron units of northern Castie

Figure 8 (caption on next page) near here

Valley were informally named, in ascesing stratigraphic order, the Clavson and Washboard units of the Ferron Sandstone Member by Cotter (1975a). Cotter's informal names are used in this report. 


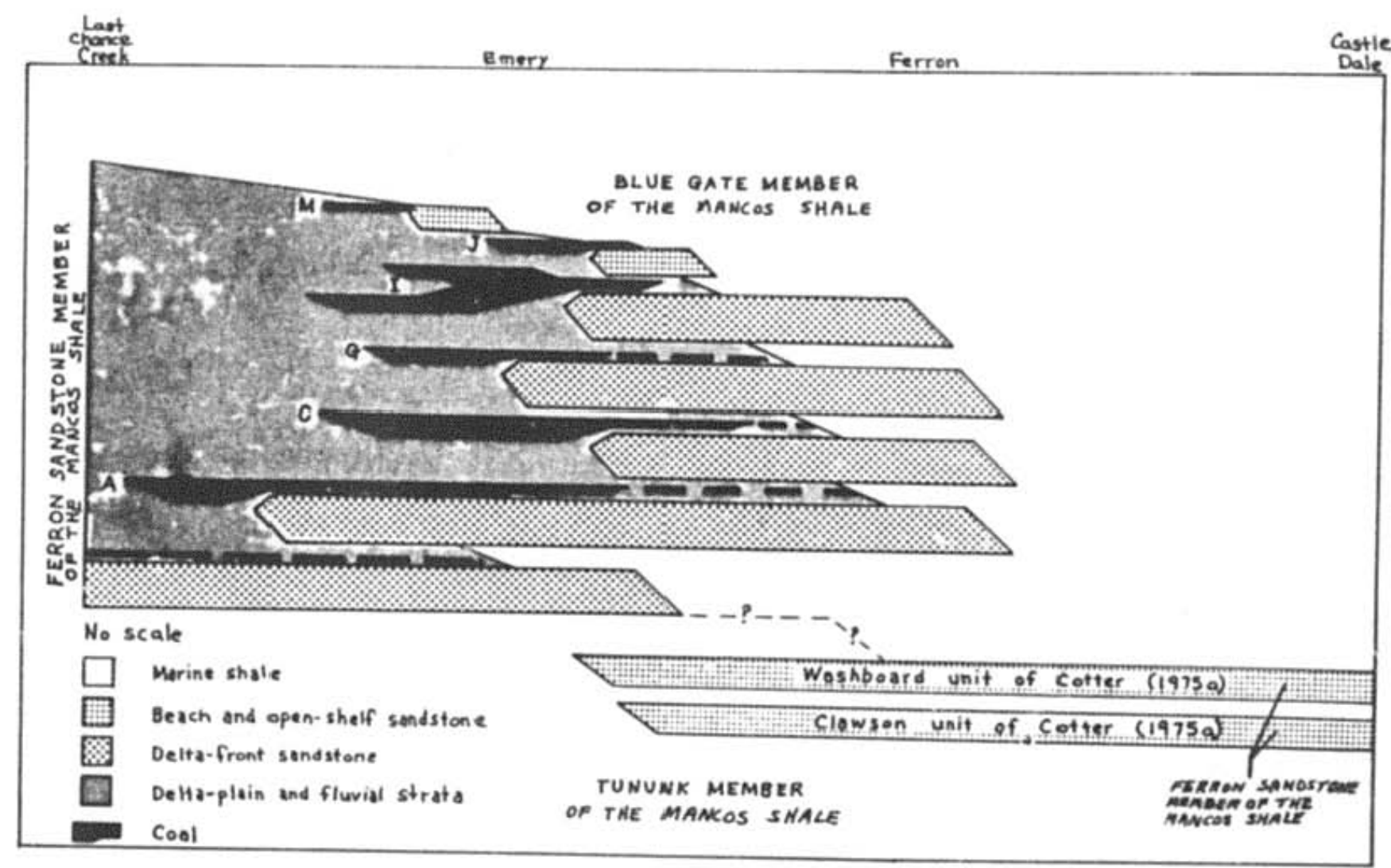

Figure 8.-- Diagrammatic southwest-nor theast section sibowing stratigraphic relationships of the various units of the Ferroh Sandstone Member and the Tununk and Blue Gate Members of the Mancos Shale in Costle Valley. Major coal beds carry the letter designations of Lupton (1916). 
The Ferron Sandstone Menber in Castle Valley, then, contalns two parts that are strat1graphically distinct and of different origin. The older, stratigraphically lower part of the Ferron cunsists of a pair of units of very fine grained, silty sandstone that accumulated in a shallow, open-marine environment situated well offshore. These units are the Clavson and Washboard units of Cotter (1975a). They are separated from the younger, upper part of the Ferron by as much as 100 feet of marine shale. The upper part of the Ferron, the product of depositiov in a delta system, is character1zed by massive beds of very fine to medium-grained sandstone and beds of coal. The upper part of the Ferron thins to the north, interfingers with marine shale of the Blue Gate Member of the Mancos Shale, and finally pinches out between Ferron and Cascle Dale. The two parts of the Ferron are not differentiated on the thickness and structure contour maps (figs. 4 and 5). The outcrop areas of the Ferron Sandstone Metber and other geologic units in the Emery area are shown in figure 9 .

Figure 9 (caption on next page) near here

FERRON SANDSTONE AQUIFER

Aquifer characteristics Thickness

The Ferron sandstone aquifer in Castle Valley consists of the vhole thickness of the Ferron Sandstone Member. The thickness of the Ferron varies considerably in the study araa (fig. 4). Along the outcrop, the Ferron thickness varies from abou: 80 feet in the northern part of Castle Valley near Mounds to 850 feet in the southern part along Last Chance Creek (Lupton, 1916, p1. IV). The Ferron also generally thickens in the subsurface downdip from the outcrop area.

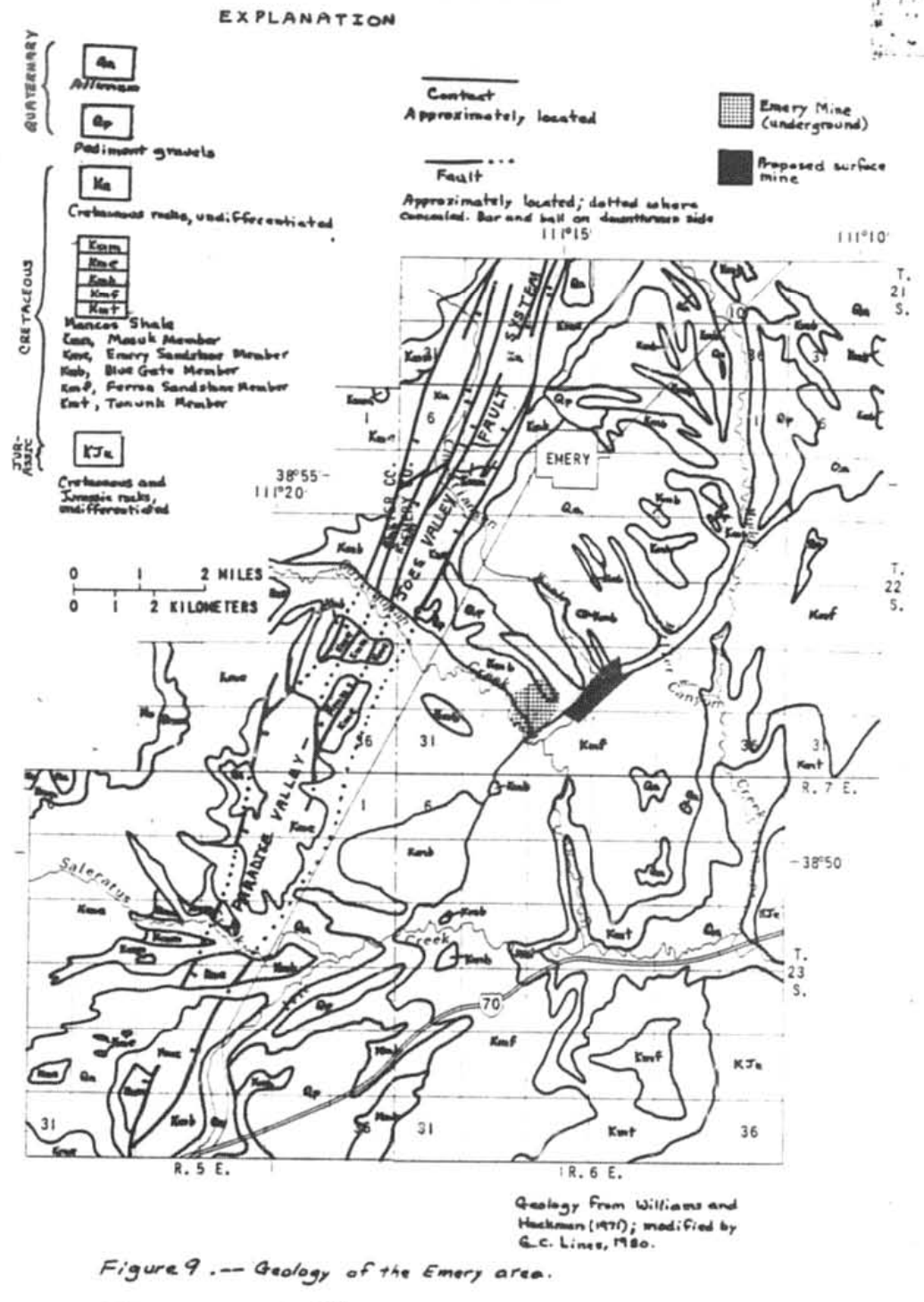

34 
Records from vells and test holes Indicate that a short distance from the outcrop area, the complate thickness of the Ferron is usually saturated with water. In the area of the proposed surface coal mine near Emery, the saturated thickness of the Ferron is about 450 feet. In the outcrop area, not all the Ferron is saturated sith water; and at the higher altitudes along the outcrop, much of $1 t$ is unseturated.

Hydraulic conductivity-

The hydraulic conductivity of a vater-bearing material is the volume of water that will move through a unit cross section of the material in unit time under a unit hydraulic gradient. The units for hydraulic conductivity are cubic feet per day per square foot $\left[\left(\mathrm{ft}^{3} / \mathrm{d}\right) / \mathrm{ft}^{2}\right]$, which reduces to $\mathrm{ft} / \mathrm{d}$. The term hydraulic conductivity replaces the term field coefficient of permeability, which was formerly used by the Geological Survey and which was reported in units of gallons per day per square foot. To convert a value of field coefficient of permeability to the equivalent value of hydraulic conductivity, divide by 7.48 ; to convert from hydraulic conductivity to coefficient of permeability, multiply by 7.48 .

Hydraulic conductivity was determined in the laboratory for 17 rock samples from the Ferron Sandstone Member obtained from core holes in the Emery area. Hydraulic conductivity was determined in horizontal and vertical directions for 15 of the samples, porosity was determined for all but one sample, and grain size was determined for 10 sandstone samples.
Results of the laboratcry determinat as are sumarized in table 1. The

Table 1 (next page) near here

data indicate a large variation in the porosity and hydraulic conductiwity of the sandstone. This may be due to differences in cementation and compaction between samples. Unconsolidated sand, similar in size and sorting, vould have a porosity of about 40 percent (Johnson, 1967, f1g. 3) as compared to the average of 16 percent for the sardstone in the Ferron.

In all the sandstone samples, the difference between horizontal and vertical hydraulic conductivities was less than one order of magnitude. The average hydraulic conductivity of delta-front sandstone samples vas $1.0 \times 10^{-1} \mathrm{ft} / \mathrm{d}$ in the horizontal direction and $9.1 \times 10^{-2} \mathrm{ft} / \mathrm{d}$ in the vertical. Similarly, hydraulic conductivity of the fluviatile sandstone samples averaged $1.5 \times 10^{-1} \mathrm{ft} / \mathrm{c}$ in the horizontal direction and $9.9 \times x^{n-2} \mathrm{ft} / \mathrm{d}$ in the vertical. Hydreulic conductivity of the shale and s1ltstone samples was much less than that of most of the sandstones, and $1 \mathrm{t}$ averaged $3.8 \times 10^{-4} \mathrm{ft} / \mathrm{d}$ in the horizontal direction and $1.3 \times 10^{-5} \mathrm{ft} / \mathrm{d}$ in the vertical. 
ITransa1ssivicy is the rate at which water is transaltted through a unit width of the aquifer under a unit hydraulic gradient. The units for transmissivity are cubic feet per day per foot $\left[\left(\mathrm{ft}^{3} / \mathrm{d}\right) / \mathrm{ft}\right]$, which reduces to $\mathrm{ft}^{2} / \mathrm{d}$. The term transalssivity replaces the term coefficient of transmissibility, which was formerly used by the Geological Survey and which was reported in units of gallons per day per foot. To convert a value for coefficient of transmissibility to the equivalent value of transmissivity, divide by 7.48 ; to convert from transmissivity to coefficient of transmissibility, multiply by 7.48 .

Nine aquifer tests were conducted on tha Ferron sandstone aquifer in the Emery area, and the results are sumarized in table 2 . Considering the thickness and

Table 2 (next page) near here

1ithology of the aquifer tapped by the discharging well at each test site, some transmissivity values calculated from the te: jree fairly well with what would be expected from the hydraulic conductivities determined in the laboratory. In some cases, particularly at test sites near the Paradise Valley-Joes Valley fault system, the computed transmissivities of several hundred feet squared per day are larger than sould be expected from the laboratory data. This is bellevea to be due to secondary permeability in the form of fractures.
None of the test wells fully penetrate the Ferron sandstone aquifer. However, where the Ferror is extensively fractured, thus increasing hydraulic connection in the aquifer, the computed transmissivities of several hundred feet squared per day fairly accurately represent the transmissivity of the full thickness of the aquifer. Tests that were conducted more than about 2 wlles from the Paradise Valley-Joes valley fault system usually indicated transmissivities of $100 \mathrm{ft} 2 / \mathrm{d}$ or less. Computed transmissivities from these tests probably most accurately represent the transmissivity of only a partial thickness of the aquifer because hydraulic connection is not as great as along the fault system.

Test results in the Emery area indicate that transmissivity of the Ferron sandstone aquifer ranges from about 200 to $700 \mathrm{ft}^{2} / \mathrm{d}$ doundip from the Ferron outcrop. (Compare figs. 9 and 10.) Transmissivity is less than $200 \mathrm{ft}^{2} / \mathrm{d}$ in

\section{Figure 10 (caption on next page) near here}

the outcrop area of the Ferron. The decrease in transaissivity in the outcrop area is due mainly to the decrease in the saturated thickness of the aquifer rather than a decrease in hydraulic conductivity. 
EXRAMATION

\section{--400 - LINE of Eacal Treme sands stout nation intions}

- sxra eo neocrsa teot
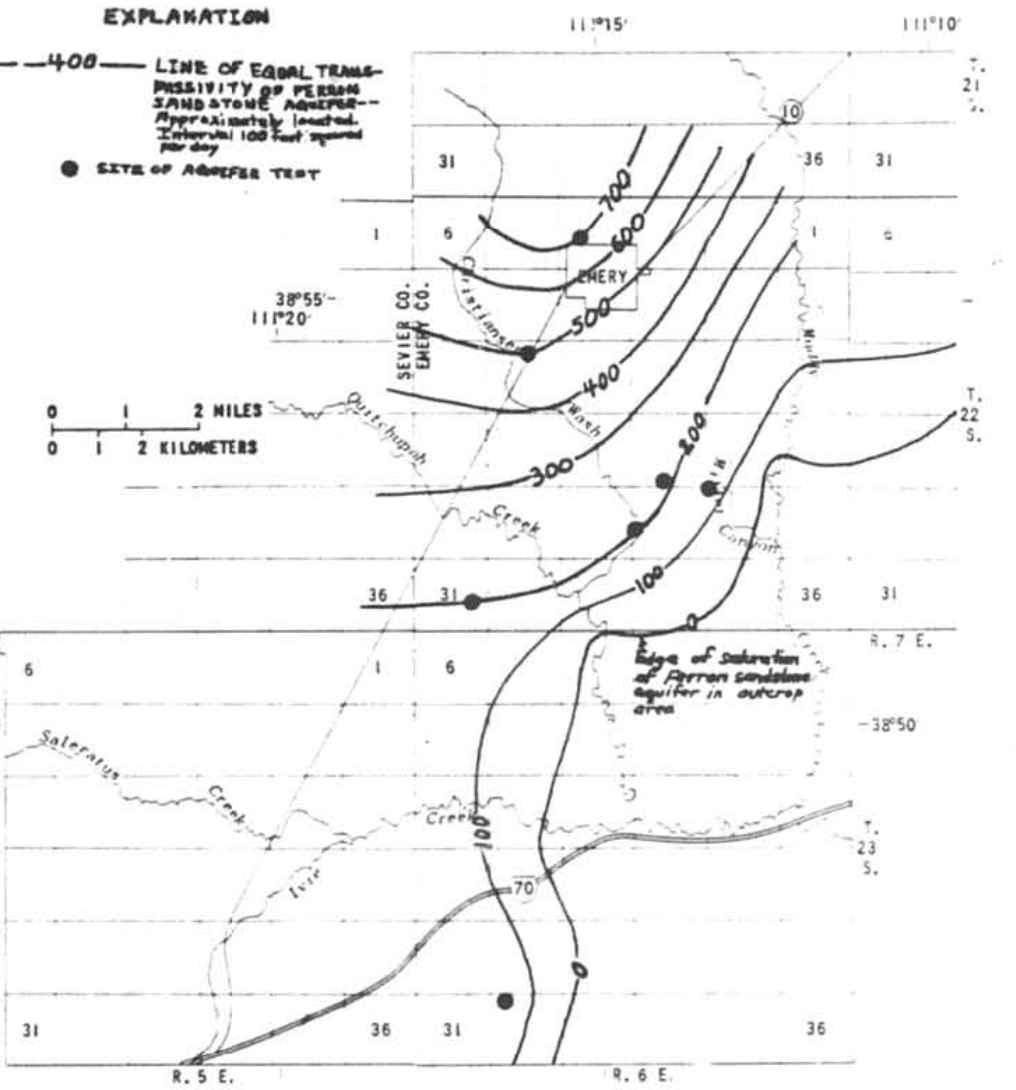

Figure 10.-- Transmissivity of the Feresn sanestone aquifer in the Emery area.
The transmissivity values in figure 10 were based on data from aquifer tests, 11thologic information, and estimates of saturated thickness in the outcrop area. Because of secondary permeability and the nonhomogenesus nature of the aquifer, the 1ines of equal transmissivity are considered to be approximate. Figure 10 is presented only to depict the general pattern of increasing transmissivity from the outcrop area toward the Paradise Valley-Joes Valley fault system. Calibration of a three-dimensional digital-computer model of the Ferron sandstone aquifer Indicated that the aquifer was simulated most accurately when transmissivity values north of about the $200-\mathrm{ft}^{2} / \mathrm{d}$ 1ine in figure 10 were reduced by $10-30$ percent. The model is discussed in a following section of this repert and 1 s documented by Morrissey, Lines, and Bartholoma (1980). 


\section{Storage}

Water in the Ferron sandstone aquifer is corfined, except for possibly a few areas in the outcrop and in the upper part of the aquifer near the Emery Mine. The vater is confined under pressure between shale and siltstone beds within the aquifer and between the enclosing shales in the Blue Gate and Tununk Members of the Mancos Shale. Where a well taps the confined aquifer, water is released from storage mainly by compression of the sandstone and less pesseable confining beds as pressure in the aquifer declines. The quantity of water that can be released from storage from the Ferron sandstone aquifer is depericent upon the storage coefficient $L^{\prime}$, which ranges from about $3 \times 10^{-6}$ to

-The storage coefficient of an aquifer is the volume of water it releases from or takes into storage per unit surface area of the aquifer per unit change in head. Storage coefficient is a dimensionless number. Under confined conditions, the storage coefficient is typically small, generally between $10^{-5}$ and $10^{-3}$. Under unconfined conditions, it is wuch larger, typically between $5 \times 10^{-2}$ and $3 \times 10^{-1}$.

$2 \times 10^{-3}$ in the confined parts of the aquifer (table 2).

Where a well taps the unconfined aquifer, water is released from storage mainly by gravity drainage; and the storage coefftcient is virtually equal to the specific yield. Aquifer tests were not conducted in an unconfined part of the Ferron sandstone aquifer. However, other studies (Johnson, 1967) have found that specific yield varies from about 0.01 in shiles to about 0.1 in sandstones that are similar to those in the Ferron. Because the Ferron consists of both sandstone and shale, storage coefficient ir the unconfined parts of the aquifer probably averages about 0.05 .

\section{Potentiometric surfaces}

The potentiometric surface (the level to which water rises in tightiy cased we11s) varies appreciably with depth in the Ferron sandstone aquifer. Where data pernit, more than one potentiometric surface is defined in order to describe the distribution of head/ in the aquifer.

- Head is defined by Lohman and others (1972, p. 7) as "the he1ght above a standard datum of the surface of a column of water (or other 11quid) that can be supported by the static pressure at a given point." The head is the sum of the elevation head and the pressure head. Under conditions to which Darcy's law aay be applied, the velocity of ground water is so small that the velocity head is neg11gib:e.

Except for the Emery area, data are lacking in Castle Valley to define the distribution of head in the Ferron sandstone aquifer and surrounding rocks. On a regional scale, however, the distribution of head in the Ferron may be similar to that in the Emery area. Petroleum-test hole (D-17-1)25ddc-1 penetrated the Ferron in the northern part of Cast1e Valley about 9 miles from the outcrop area; and watar reportedly flowed frem the hole at land surface, which was at an altitude of 7,040 feet. (See table 5.) The water level in well (D-17-10)16dda-1, which penetratee the Ferron only about 1 mile from the outcrop area, was within a few feet of land surface during 1979 at an altitude of about 5,670 feet. Information trom these two sites indicates that head in the Ferron incieases downdip from the outcrop area. This is consistent with head distribution observed near Emery, which is discussed in detall in the following sections of the report. 
In the Emery area, downdip from the outcrop of the Ferron, head in the Ferron sandstone aquifer generally increases with depth. In most of this area, head in the Ferron is above the vater table in overlying rocks. In the outcrop area of the Ferron, where there is a small amount of recharge from precipitation and where water from the Ferron leaks dowr ard into the underlying Tununk Member, head in the aquifer decreases with depth.

\section{Basal section}

Figure 11 shows the configuration of the potentiometric surface of the basal

Figure 11 (caption on next page) near here

section of the Ferron sandstone aquifer (below the A-coal seam) in the Emery area. The contours are based on measurements of different accuracy. The potent1ometric surface vas determined accurately at 11 sites--in tightiy cased wells that tap only the basal section and in uncased test holes drilled for the Geological Survey where an erpandable packer was used to 1solate the basal section.

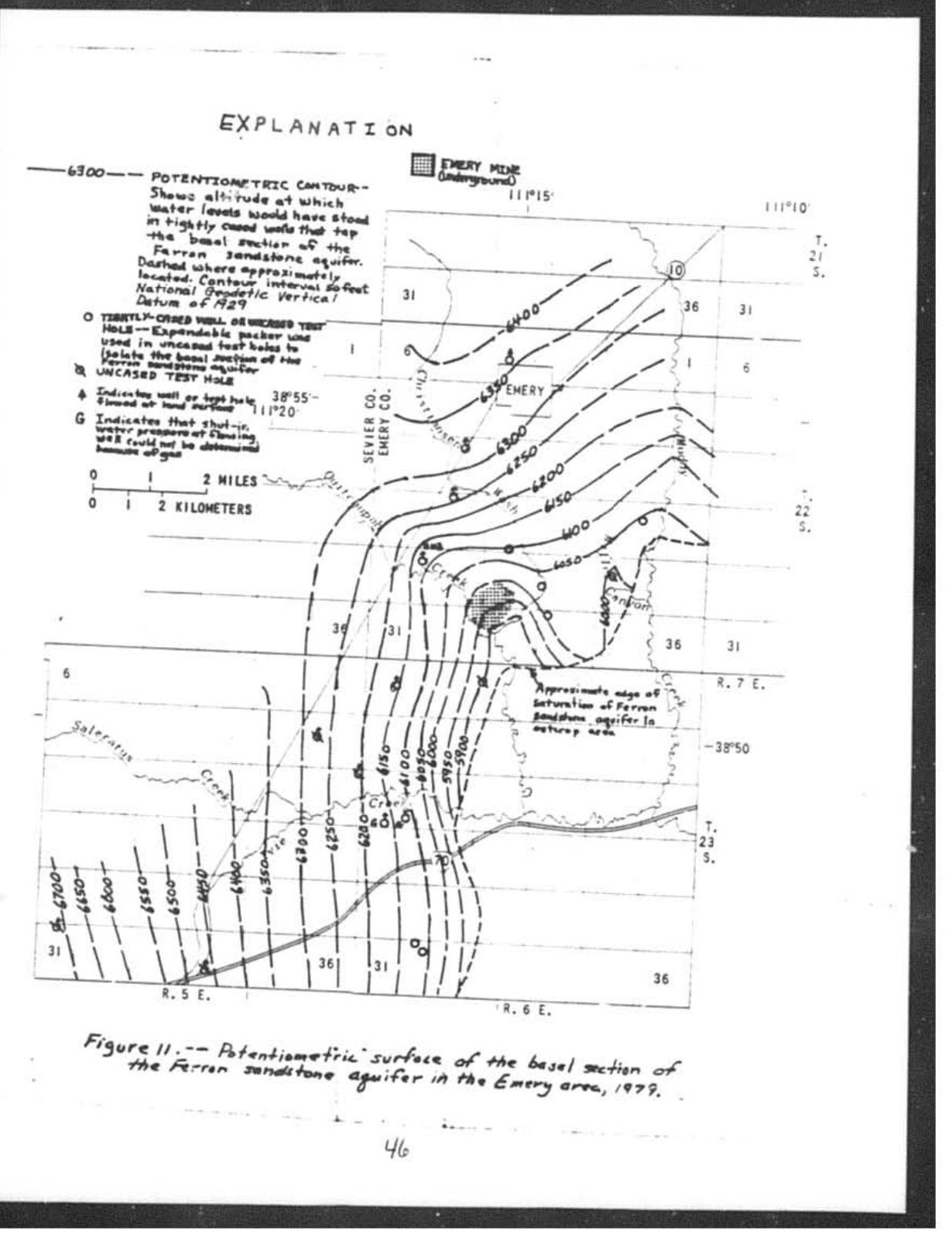


Data from s1x other uncased test holes that penetrated the basal section also were considered in drawing the potentiometric contoucs. Downdip from the outcrop of at Ferron, ffour of the test holes flowed at land surface. Because the holes vere uncased, no shut-1n pressures vere measured. Thus, the only thing known of the potentiometric surface was that it was at a higher altitude than land surface. Water levels also were measured, or obcained from an electric 10g, in two nonflowfag test holes that penetrated the basal section. Because the holes were not cased through the upper coal-bearing section of the Ferron Sandstone Member and the Blue Gate Members, water levels in the holes probably did not accurately represent the altitude of the potentiometric surface of the basal section of the Ferron sandstone aquifer. In most areas, excipt on the outcrop of the Ferron, the potentiometric surface of the basal section was probably at significantly higher altitudes (as much as 150 feet at one packer-test site) than the water levels in the uncased holes. Nevertheless, the water-level data from the s1x uncased test holes were useful in drawing the potent1ometric contours, as the water levels in most cases represented the minimum altitudes to which water would have risen had the test holes been tightly cased.

Upper section

Configuration of the potentiometric surface of the upper section of the Ferron sandstone aquifer (above the base of the I-coal seam) is shown in figure 12. Near the Emery Mine, many coal-test holes have been cased and are open only

Figure 12 (caption on next page) near here

to the upper section. In addition, packer tests were conducted in two Geological Survey uncased test holes to determine the potentiometric surface of the upper section.

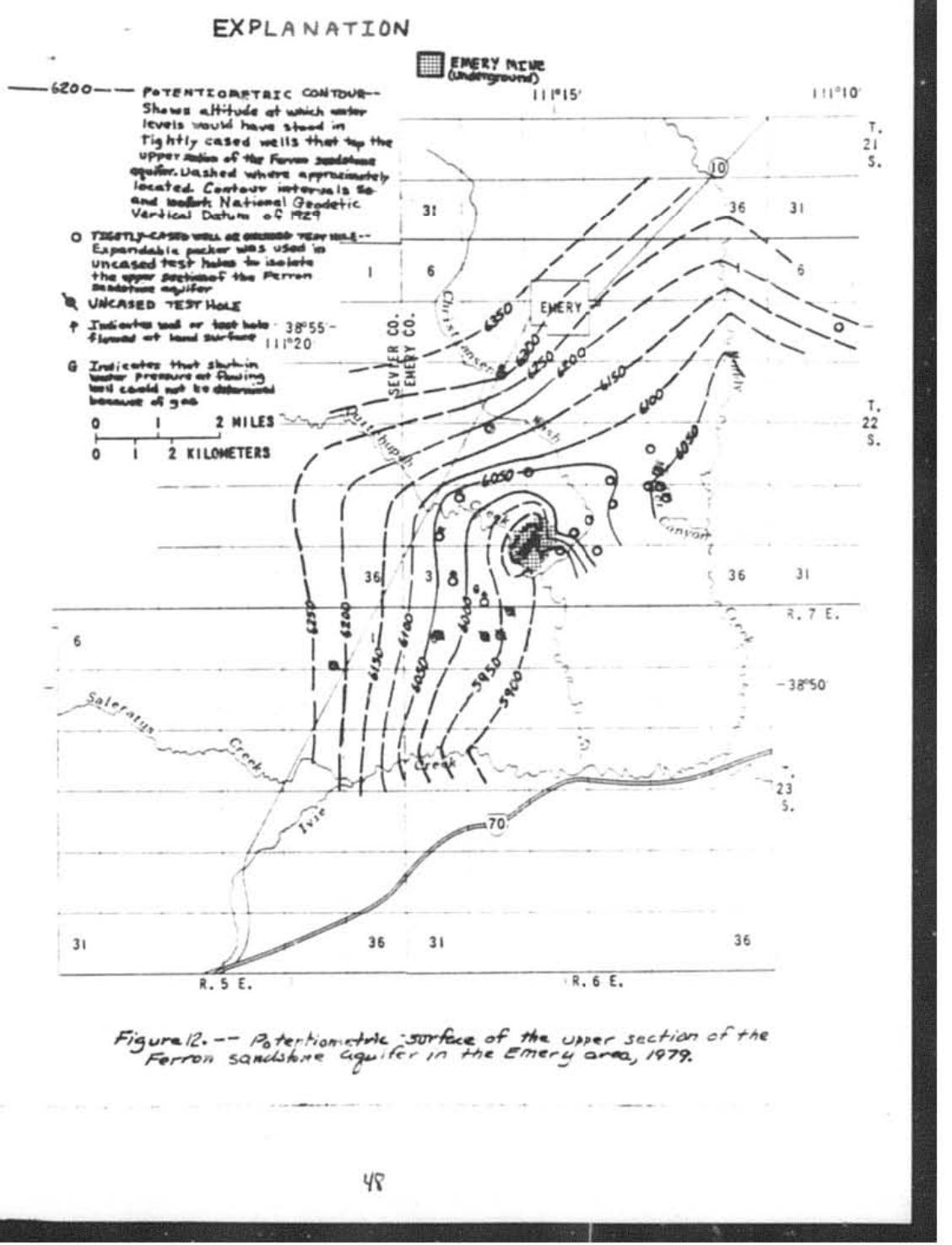


In addition to water levels measured in wells and test holes, the altitude of the I-coal seam in the Emery Mine was also considered in drawing potentiometric contours for the upper section. Observations in the mine indicate that the aquifer has been dewatered above much of the I-seam. Vater production in the mine during 1979 was concentrated in those areas farthest downdip, near the working faces at the I-seam. Much of the old mine workings produced no water.

Most of the water-level data from which the potentiometric-surface maps in figures 11 and 12 were derived were collected during 1979. However, some of the data from coal-test holes are 4 to 5 years older. Even though these earlier data were used to compile the maps, the configurations of the potentiometric surfaces should fairly well represent conditions that existed in 1979.

It should be noted that the Ferron sandstone aquifer has yielded hydrogen sulfide gas and occasionally methane or carbon dioxide gas to some wells in the Emery area. When the wells flowed at the land surface, it was not possible to accurately determine shut-in pressures because of the gas.

\section{Adfacent water-bearing zones}

The approximate configuration of the water table (the level at which pressure is atmospheric) 1n rocks that overlie the Ferron sandstone aquifer in the Emery area is shown in figure 13. The altitude of the water table in rocks that overlie

Figure 13 (caption on next page) near here

the Ferron is defined in order to deterwine the direction of vertical movement of water. During the summer of 1979, the water table in many areas was in the Blue Gate Member; but on the benches north of Quitchupah Creek, the water table was commonly in pediment gravels ond alluvium. Water-level data were available from 11 vells and test holes to define the water table. Along perennial streams and 1rrigation canals and at springs that issue from the Blue Gate and pediment grave1s, the water table was assumed to be at the altitude of land surface. Along ephemeral streams, the vater-table contours were drawn at an altitude below land surface. The vater table was assumed to be within 50 feet of land surface in areas with phreatophytic growth.

No data are available to define the distribution of head in the Tununk Member which underlies the Ferron sandstone aquifer. It is believed that in those areas where head in the overlying Ferron increases with depth, head in the Tununk also increases with depth. In most areas, the potentiometric surface of the upper part of the Tununk 1s probably at a s11ghtly higher altitude than the potentiometric surface of the basal Ferron. In the Ferron outcrop area, head in the aquifer decreases with depth and 1s probably a fev feet higher than the potent1ometric surface of the upper part of Tununk. 


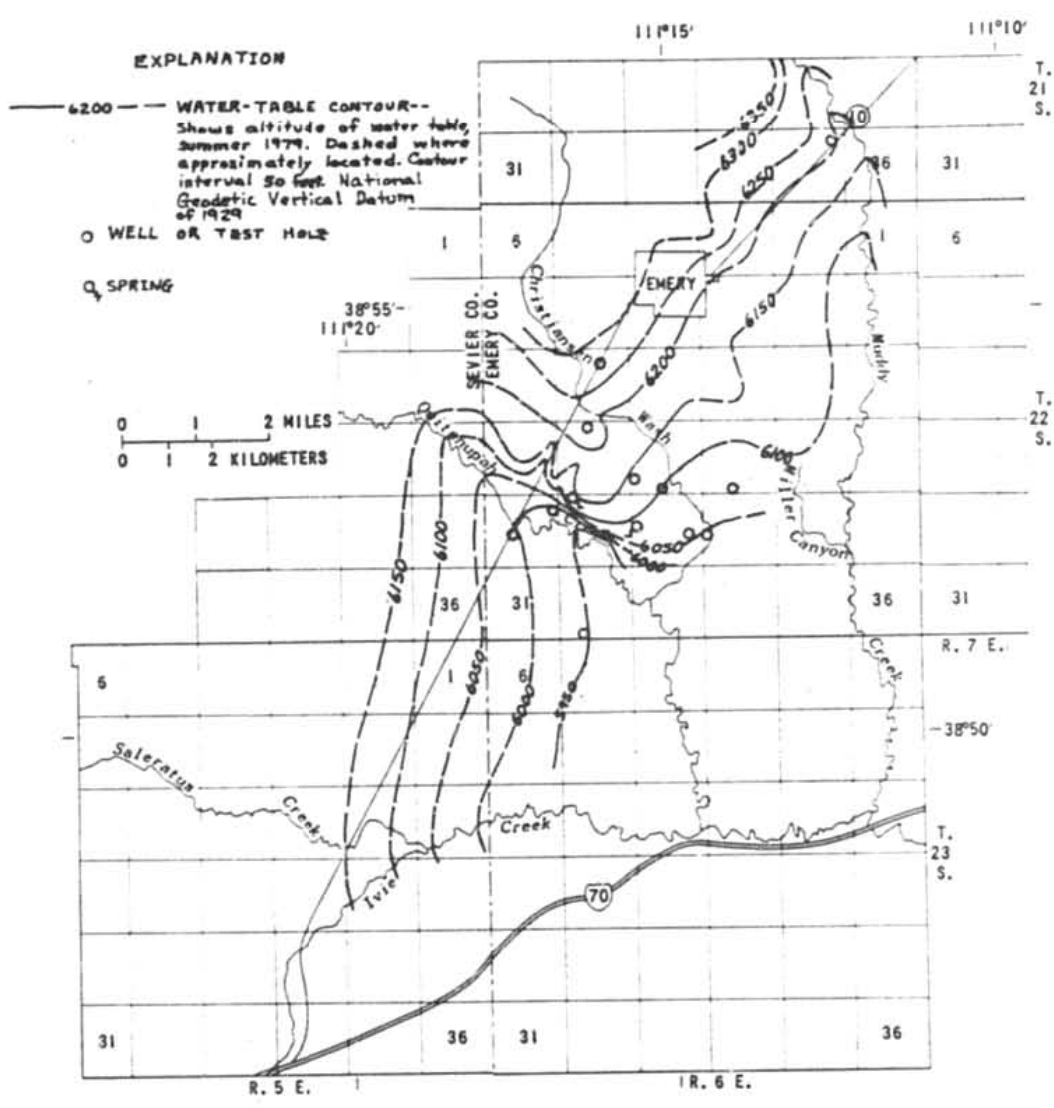

Figure 13. - C Configuration of the water table in rocks that overlie the Ferron sandstone aquifor in the Emery

Water-1evel changes

Monitoring of water levels in the Emery area started in 1975. During the course of this study, additional observation vells were constructed, and water levels or shut-1n pressures vere measured monthly in 18 wells. Little water-1evel data exist for the years prior to 1975; thus, an evaluation of long-term changes is not possible.

Water-level hydrographs for four representative wells in the Emery area are shown in figure 14 . Well (D-22-6)1/abc-1 is unused, and 1t taps the basal

F1gure 14 (caption on next page) near here

section of the Ferron sandstone aquifer. The well is about 2 miles from the Enery public-supply well, which also taps the basal section. Except for seasonal fluctuations, water pressure at the well declined from mid-1975 through 1979, with a net decline of 7 feet. When the well was drilled in May 1973, water pressure was reported as 74 feet above land surface, as contrasted to a measured water pressure of 41 feet above land surface in December 1979.

We1i $(D-22-6) 23$ bcc-1 bottoms in the basel section approximately 2.5 miles from the Emery Mine. Casing perforations in the well are below the Blue Gate Member, and the well taps both the basal and upper sections of the Ferron sandstone aquifer. The net water-1evel dec11ne was about 16 feet from m1d-1975 through 1979 . 


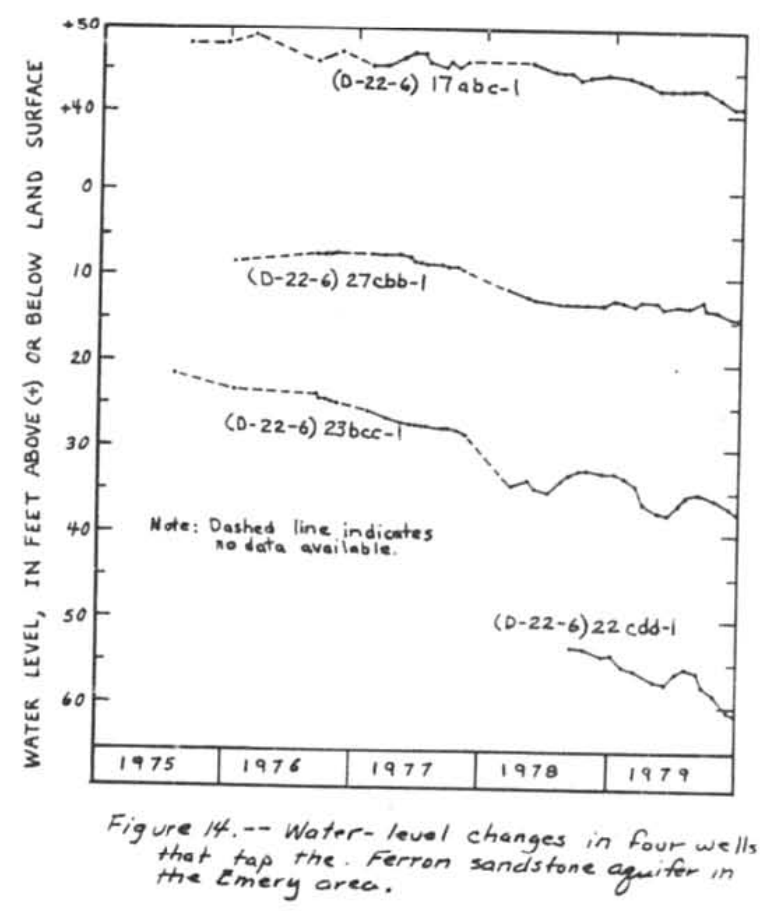

We11 (D-22-6) 27cbb-1 also bottoms in the basal section, but the top perforations in the vell casing are opposite the Blue Gate Member. The well is in the proposed surface-mine area about 1 mile from the Emery Mine. Water levels In nearby wells that were constructed during this study indicate that the water leve1 in well (D-22-6) $27 \mathrm{cbb}-1$ closely approximates the altitude of the water table in the Blue Gate. From early 1976 through 1979 the vater level in the well has dropped about 5 feet.

Heil $(D-22-6) 22 \mathrm{edd}-1$ is at alle from the northestern edge of the proposed surface mine. The $w i \quad$ in a shale immediately below the I-coal seam at a depth of 275 feet. The upper 100 feet of the hole was cemented around the casing to seal off water in the Blue Gate, and the water level in the well represents the potentiometric surface of the upper section of the Ferron sandstone aquifer. The water level in the well declined about 8 feet $\mathrm{from}$ the date of 1 ts construction in the summer of 1978 through 1979.

Precipitation at 1ong-term U.S. Oceanic and Atmospheric Administration stations in and near Castle Valley and at rain gages installed for this study indicate that precipitation in the arca between 1975 and 1979 vas about 90 percent of normal and averaged about 7 inches per year in the Emery areã. Belowaverage precipitation in the area can explain some of the declines in water levels, but most of the declines probably are due to manmade withdravals of water from the Ferron sandstone aquifer. 
Movement and age of vater

Water moves ie-orally through the Ferron sandstone aquifer downgradient at approximately right angles to the potentiometric contours shown in figures 11 and 12. On a regional scale, the strike and dip o. beds in the aquifer have litile effect on the movenent of water. Movement of water is governed instead by the location and altitude of sources of recharge and discharge. In the Emery area, vater moves through the aquifer from areas of subsurface recharge in the vest and northwest tovard areas of manmade discharge and toward areas of natural discharge along the Ferron outcrop.

The rate at which vater moves laterally through the aquifer can be estimated frow the following equation (Lohman, 1972, p. 10):

$$
\mathrm{V}=\frac{\mathrm{KI}}{\partial}
$$

where $V$ = velocity, in feet per day,

$K=$ hydraulic conductivity, in feet per day,

I = hydraulic gradient, a decimal fraction, and

$\theta$ - effective porosity, a decimal fraction.

Assuming a hydraulic conductivity of $1 \mathrm{ft} / \mathrm{d}$, a hydraulic gradient of 50 trim1 or 0.0095 , and an effective porosity of 5 percent, then

$$
V=\frac{(1 \mathrm{ft} / \mathrm{d})(0.0095)}{0.05}
$$$$
\mathrm{V}=0.2 \mathrm{ft} / \mathrm{d} \text { (rounded) }
$$

It should be stressed that $0.2 \mathrm{ft} / \mathrm{d}$ would be the average fluid velocity through the aquifer at the assumed conditions. It does not necessarily equal the actual velocity between any two points in the aquifer, which would depend on the flow path followed. Water moving along an open fracture would move much faster than water moving through pore spaces between sand grains.

Water samples from the basal section of the Ferron sandstone aquifer vere obtained from vell (D-22-6)17abc-1 and Geological Survey test hole (D-23-6)6acc-1, and carbon-14 dating of the two samples indicated ages of 28,000 and 31,000 years. Between the recharge area and sampling points, solution of carbonate rocks is a possible source of error in the dating technique. Carbonate dissolved from rocks would be depleted of the carbon-14 radioisotope. The degree to which this process is taking place is unknown, but it is saie to assume that the dating indicates the maximum possible age.

In addition to 1ateral flow through the Ferron sandstone aquifer, potentiometric-surface data also indicate that significant vertical components of flow exist. Along the outcrop of the Ferron, where a small amount of recharge from precipitation occurs, water moves downvard through the aquifer and some water leaks into the underlying Tununk Member. In most areas doundip from the outcrop, head in the aquifer increases with depth, and water moves upward into the Blue Gate Member.

Dewatering of the Emery Mine (the largest manmade discharge from the Ferron sandstone aquifer) has induced movement of water toward the mine from all sections of the aquifer. Most water produced from the mine has come from the upper section of the aquifer, but the potentiometric surface of the basal section also has been affected. 
Two water samples vere collected from seepage areas in the roof of the Emery Mine and were analyzed for concertrations of tritium (a radioisotope of hydrogen with an atomic weight of 3 ). Both samples contained detectable concencrations of tritium--12 end 21 picocuries per 11ter (Teledyne Isotopes, written commun., November 2, 1979). Prior to testing of nuclear weapons in the eariy 1950's, natural tritium levels were about 26 picocuries per 1iter. Tritium levels reached a peak in the Northern Eemisphere in 1963 when concentrations in the atmosphere exceeded the natural level by approximately three oriers of magnitude (Thatcher and others, 1977, p. 8). Because tritiun has a half-1ife of only 12.33 years, some of the mine water aust have been recharged to the aquifer since the early 1950 's. A number of possible sources of recharge water are Quitchupah Creek and Christiansen Wash, 1rrigation water applied to load overlying the mine, and precipitation on land overlying the mine.

The concentration of tritium was also determined in a water sample from well (D-22-6) 31dab-1, a flowing well about 1 mile southwes: of the Emery Mine. The well taps the upper section of the Ferron sandstone aquifer, and potentiowetric contours (fig. 12) indicate that the well is upgradient from the mine. As might be expected, tritium concentration in the water was less than the detectable 1imits of 6 picocuriss per 11ter (Teledyne Isotopes, written commun., November 2,1979 ).

\section{Recharge and discharge}

Sources of recharge to and discharge from the Ferron sandstone aquifer in the Emery area during 1979 are shown diagramatically in figure 15 . The estimate

Figure 15 (caption on next page) near here

of recharge and discharge shown in figure 15 indicate that discharge exceeded recharge by about $0.1 \mathrm{ft}^{3 / 3}$; however, they are only order-of-magnitude estimates. Water-1evel declines in observation vells in the Emery area during $197 \%$ indicate that the amount of storage in the aquifer declined, out the degree of lmbalance between recharge and discharge is not known precisely.

\section{Subsurface infiow}

The largest source of recharge to the Ferron sandstone aquifer in the Emery area 1s subsurface flow, probably from the Wasatch Plateau. Most of the water in the aquiter in the Emery area probably uriginates as precipitation on the plateau, and most, if not all, is transmitted into the area along the highiy permeable zone along the Paradise Valley-Joes Valley fault systen. Previously described carbon-14 dating indicates that motement of water from the original recharge areas to tie Enery area probably takes thousands of years.

A reasonable estimate can be made of the amount of subsurface inflow to the aquifer from the west in the Emery area. Using potentiometric-surface maps (f1gs. 11 and 12) to determine hydraulic gradients, transmissivity developed from calibration of the computer model (Morrissey and others, 1980, fig. 5) and Darcy's law (Lohman, 1972, p. 10), subsurface 1nflow to the Emery area is estimated to have averaged $2.4 \mathrm{ft}^{3} / \mathrm{s}$ during 1979 or about 1,700 acre-feet per year. Data are lacking to accurately estimate subsurface inflow to the Ferron in other areas of Castle Valley. 


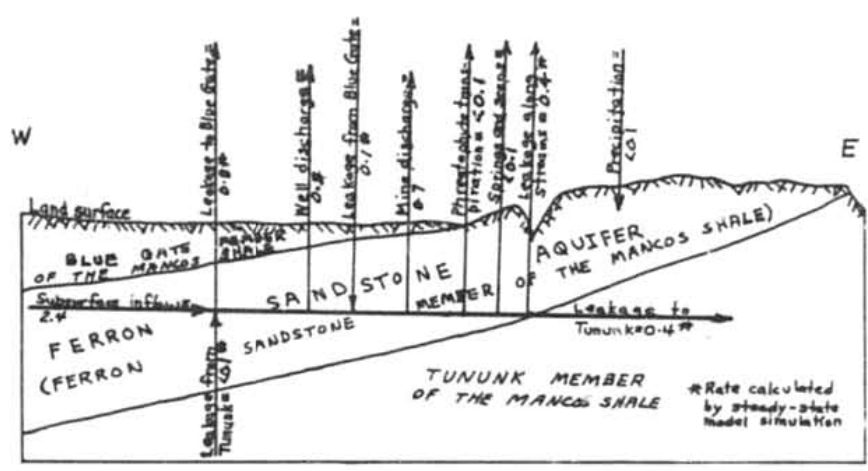

Figure 15.-- Diagrammatic section showing sources of recharge to and discharge from the ferron sandstone aquifer in the Emery area, 1979. Recharge and discharge values are in cubic feet per socond.

\section{Precipitation on outcrop area}

Annual precipitation on the $100=1^{2}$ outcrop of the Ferron Sandstone Member In Castle Valley averagee about 8 inches (U.S. Weather Bureau, 1963).

Preci,1tation occurs about equally as rain from thunderstorms and as snow.

Thunderstorms contribute little recharge because the siopes on the Ferron outcrop are usually steep, there is 1ittle or no soil cover in most of the area, and

runoff is rapld. Most of what 11ttle recharge occurs on the outcrop area probably takes place during the spring when snow melts slowly.

In those areas of the lower Dirty Devil River basin where annual precipitation averages less than 12 inches, Hood and Danie1son (1979, table 4) estimate that recharge to bedrock aquizers averages, at most, 0.5 percent of precipitation. This is also probabiy the maximum amount that could be recharged on the Ferron outcrop, and it amounts to only about 200 acre-feet per year for the entire $100 \mathrm{ml}^{2}$ of outcrop area in Castle Valley.

The Ferron outcrop, particularly in the southern part of Castle Valley, is deeply cut by stream channels as shown in figure 6 . Much of the water that recharges the aquifer in the outcrop is discharged close to the recharge areas by leakage to the underlying Tununk Member and by leakage to alluviun along streams. In most areas, 11ttle or no recharge from the outcrop area reaches the main body of the aquifer downdip from the outcrop.

The Ferron sandstone aquifer in the Cleveland, Elmo, and Wellington areas (the clauson and Washboard units of Cotter) 1s separated fron the main body of the Ferron that underlies the Wasatch Plateau and Castle Valley to the south. (See fig. 8.) Unlike the Emery area, recharge to the aquifer in these areas may be 1 inited to a small amount of recharge on the narrow strip of Ferron outcrop. 
Leakage

The Ferron sandstone aquifer 11 es between relatively impermeable shales 1n the Blue Gate and Tununk Members, but there 1s some movement of water between these three zonts. In most of the Emery area downdip from the Ferron outcrop, heads in the aquifer are usually higher than the vater table in overlying rocks, and there 13 upward leakage of water into the Blue Gate. Much of the water in the overlying Blue Gate is consumed by greasewood (Sarcobatus verniculatus), a phreatophyte. Computations using the three-dimensional digital-computer model of the Ferron sandstone aquifer indicate that upward leakage fron the Ferron Into the Blue Gate averaged about $0.8 \mathrm{ft}^{3} / \mathrm{s}$ during 1979, or about 600 acre-feet per year in the Emery area (Morrissey and others, 1980, f1g. 2).

It should be noted that records of many wells and test holes drilled in Castle Valley indicate that the shale in the Blue Gate Member is "dry." In most cases, the use of the term "dry" refers to the lack of water production when drilling and does not indicate that the shale was unsaturated. Test holes (D-22-6) $27 \mathrm{cbb}-4$ and 6 bottom 1n the Blue Gate in the proposed surface-mine area. Both holes vere drilled with an air-rotary drilling rig, and shale cuttings appeared dry when drilling. The test holes contained no water between the time drilling ceased and the holes were cased, but over a period of several days both holes partly filled with water to the approximate level of the vater table.

Near the Emery Mine, the potentiometric surface of the upper section of the Ferron sandstone aquifer has been lowered to a level below the water table in the Blue Gate Metmber by mine dewatering. This is the only area near Emery where water-level data Indicate that water in the Blue Gate was leaking into the Ferron during 1979. Computations using the computer model indicate that leakage from the Blue Gate to the Ferron near the Emery Mine averaged about $0.1 \mathrm{ft}^{3 / 3}$ during 1979 , or about 70 acre-feet per year.
Along the Paradise Valley-Joes Valley fault system, hydraulic connection between the Blue Gate and Ferron sandstone aquifer probably has been increased by fracturing. Well (D-22-6) $19 \mathrm{cdb}-1$ bottoms in the B1ue Gate approximately 300 feet above the Ferron, and the well had a sustained flow of $20 \mathrm{gal} / \mathrm{min}$ during the summer of 1979. The dissolved-solids concentration 1 in the vater was $808 \mathrm{mg} / \mathrm{L}$ (table 6) and was typical of water frota the Ferron and not the Blue Gate. It is belleved that when the well $1 \mathrm{~s}$ allowed to slow, most of the water 1s actually derived from the Ferron, although it has probably moved freely through fractures Into the Blue Gate.

Head in the underlying Tununk Member and the direction of water movement between the Tununk and Ferron sandstone aquifer are unknown. It 1s probably safe to assume that downdip from the Ferron outcrop and away from mafor manmade sources of discharge from the Ferron, the exchange of water between the two units is neg1igibls. Computations using the computer model indicate that during $197 \mathrm{~s}$ in the Emery area less than $0.1 \mathrm{ft}^{3} / \mathrm{s}$ (less than 70 acre-feet) probably leaked upward into the Ferron from the Tununk, all in areas doundip from the Ferron outcrop. 
In much of the outcrop area of the Ferron near Fmery, heads in the Ferron sandstone aquifer decrease with depth. Water probably leaks from the Ferron into alluvium in the bottoms of the deeply incised stream canyons and into the underlying shales of the Tununk. Yuch of the water in the alluvium is consumed by phreatophytes, mainly greasewood. Most of the water that leaks into the Tununk evaporates on the barren shale slopes beneath the Ferron outcrop where salt accunulates through summer and fall. (See fig. 16.) Computations using

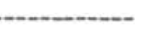

Figure 16 (caption on next page) near here

the computer model indicate that during 1979 in the Emery area leakage to alluvium along streams and leakage to the Tununk each probably averaged about $0.4 \mathrm{ft}^{3} / \mathrm{s}$.

Transpiration of phreatophytes

Although many areas in Castle Valley support dense phreatophyte growth, few phreatophytes obtain water directly from the Ferron sandstone aquifer. Most phreatophytes in Castle Valley obtain water from alluvium along streams and from the shallow saturated zone in the Blue Gate Member. Phreatophyte growth on the Ferron outcrop is limited by the depth to vater and poor soll conditions. The few phreatophytes (mainly greasewood) that obtain water from the Fer-on grow along a narrow strip about 0.2 mile wide east of the contact between the Ferron and the Blue Gate. Depth to the saturated zone in this area is less than about 50 feet.

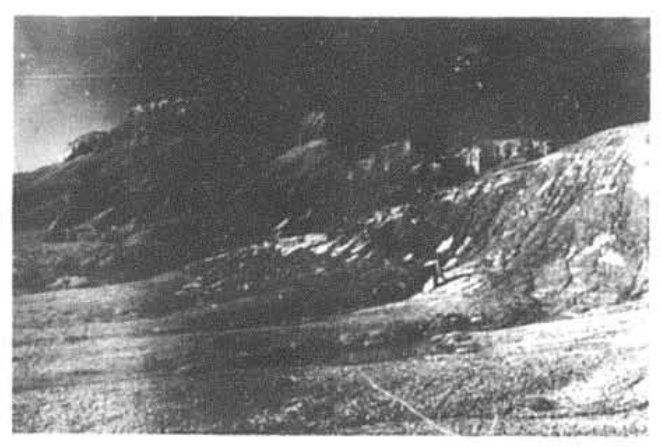

Figure 16.--Salt on the barren shale slopes of the Tununk Member of the Mancos Shale where ground water has evaporated. Overlying Ferron Sandstone Member of the Mancos Shale and Coal C11ffs in background. 
Approximately 440 acres of sparse phreatophyte growth on the Ferron outcrop 1n the Emery area vas mapped using aerial photegraphs. Using a method by Criddle, darr1s, and Willardson (1962, p. 12 and 13), trar.spiration of water directly from the Ferron in the Emery area during 1979 \% estimated to have averaged $0.04 \mathrm{ft}^{3 / \mathrm{s}}$ (about 30 acre-feet per year).

\section{Springs and seeps}

Numerous seeps 1ssue from the Ferron sandstone aquirer in Castle Valley, but only four springs were found with discernible flows. Springs (D-22-6)23dda-S1, (D-23-6)17dba-S1, and (D-24-5)13bcd-S1 all 1ssue from the basal section of the Ferron near the contact with the Tununk Member along Muddy Creek, Ivie Creek, and Willow Springs Wash. The fourth spring, (D-22-6)23cdc-S1, 1ssues from the upper section of the Ferron at the head of Miller Canyon near the contact with the Blue Gate Member. Records for these springs and chemical analyses of the water, where avallable, are listed in tables 5 and 6 . Continuous-discharge records at springs are not avallable, and it is difficult to estimate the water discharged through the seeps. The discharge of springs and seeps issuing from the Ferron in Castle Valley, however, probably does not exceed $0.2 \mathrm{ft} \frac{3}{3}$, or about 140 acre-feet per year. In the Emery area, the combined discharge of springs and seeps from the Ferron is probably about half this amount.

Lupton (1916, p. 16) described a spring that issued from the Ferron at the head of Short Canyon in the SW/4 sec. 24, T. 21 S., R. 7 E., and that supplied "sufficlent excellent water for a few head of stock the year round." This site was visited in June 1978 and November 1979. An empty st -ck-vatering tank was found, but no spring flow was observed.

\section{Well discharges}

During 1979 in Castle Valley, 18 wells tapped the Ferron sandstone aquifer for purposes other than hydrologic testing. Water from the Ferron was used for public supply in the town of Emery, coal washing, stock vater1ng, a small amount of 1rrigation, and domestic supply at three ranches.

Records from a meter on the discharge 11ne of the Emery municipal vell, $(D-22-6) 4 \mathrm{cab}-1$, indicate that the discharge averaged $0.2 \mathrm{ft}^{3} / \mathrm{s}$ during 1979. Three wells were used for coal washing at the Dog Valley Mine 1n T. 23 S., R. 6 E., and the total discharge averaged about $0.04 \mathrm{ft}^{3} / \mathrm{s}$ dur1ng 10 months of operation 1n 1979 (Western States Minerals Corp., written commun., February 14, 1980). Discharge from the remainder of the Ferron wells in Castle Valley averaged about $0.07 \mathrm{ft}^{3 / 3}$.

\section{Mine dewatering}

Devater1ng of the underground Emery Mine was the largest source of marmade discharge from the Ferron sandstone aquifer in Castle Valley during 1979. Fror discharge measurements at the end of the mine-discharge 1ine and pumping time furnished by Consolidation Coal Co., mine pumpage is estinated to have averaged $0.6 \mathrm{ft}^{3} / \mathrm{s}$ during 1979. An additional $0.1 \mathrm{ft}^{3} / \mathrm{s} 1 \mathrm{~s}$ estimated to have been removed from the mine for showers and by evaporation.

Discharge from the mine increased during 1979. The discharge averaged about $0.5 \mathrm{ft}^{3} / \mathrm{s}$ during January 1-July $19,0.6 \mathrm{ft}^{3} / \mathrm{s}$ dur-1ng July 20 -0ctober $8,0.8 \mathrm{ft}^{3} / \mathrm{s}$ during October 9-November 1 , and $0.7 \mathrm{ft}^{3} / \mathrm{s}$ during the remainder of the year. As the underground mining progresses toward the Paradise Valley-Joes Valley fault system into areas with higher aquifer transmissivity, wine dewatering should increase. 
The largest quantities of vater are available from the Ferron sandstone aquifer with1n about 2 miles of the Paradise Valley-Joes Valley fault system in the Emery area. In this area, the aquifer transmissivity has been increased by fracturing, and several wells have been constructed that are capable of producing more than $100 \mathrm{gal} / \mathrm{min}$. (See we11s (D-22-6) $4 \mathrm{cab}-1$ and $2,17 \mathrm{abc}-1,30 \mathrm{dcb}-1$, and 3ldab-1 in table 5.) Most of the welle in this area flow naturally at land surface at rates less than $100 \mathrm{gal} / \mathrm{min}$, but discharges could be increased by pumping. Wells that fully penetrate the aquifer in this area could be expected to produce 100 to $500 \mathrm{gal} / \mathrm{min}$ if pumped.

E1seuhere in the Emery area and farther south in Castle Valley, individual wells could be expected to produce 10 to $50 \mathrm{gal} / \mathrm{min}$ from the Ferron sandstone aquifer. Yields would be greatest from fully penetrating wells in areas wit: the greatest saturated thickness and transmissivity. Saturated thickness and transmissivity decrease in the outcrop area of the Ferron. Wells within about 1 mile of the contact with the underlying Tununk Member probably would yield less than $10 \mathrm{gal} / \mathrm{m} 1 \mathrm{n}$.

In the northern two-thirds of Castle Valley, several miles from major faulting and where the Ferron is less than 300 feet thick, ylelds of individual wells that tap the Ferron probably would not exceed $10 \mathrm{gal} / \mathrm{min}$. As pointed out earlier, the Ferron sandstone aquifer in the Cleveland, Elmo, and Wellington areas is separated from the main body of the Ferron that underlies the wasatch Plateau and Castle Valley to the south. Unllke the Emery area, recharge to the aquifer in the northern part of Castle Valley may be limited to a small amount of recharge from precipitation on the narrow strip of Ferron outcrop. Well (D-17-10)4bba-1 reportedly penetrates the Ferron about 0.5 mile south of E1mo, and the driller reported that no water was encountered. About 3 miles farther south, well (D-17-10)16dda-1 taps the Ferron and produces enough water for one household.
Chemical analyses of vater from vells, test holes, springs and the Emery Mine in Castle Valley, are 11sted in table 6.

As shown in fagures 17 and 18, the concentration of dissolved solids in

Figures 17 and 18 (Laptions on next page) near here

water from the Ferron sandstone aquifer in the Emery area increases eastward from the Paradise Valley-Joes Valley fault system toward the Ferron outcrop. Comparison of figures 17 and 18 1ndicates that in most areas dissolved-solids concentrations also increase upward in the aquifer.

In the Emery area, deterioration of water quality in the Ferron sandstone aquifer usually is due to increased concentrations of dissolved sodium and sulfate. Shales in the Mancos Shale contain larga quantities of soluble sodium-sulfate minerals such as mirabilite $\left(\mathrm{Na}_{2} \mathrm{SO}_{4} \cdot 10 \mathrm{H}_{2} \mathrm{O}\right)$ and thenardite $\left(\mathrm{Na}_{2} \mathrm{SO}_{4}\right)$ (Wadde11 and others, 1979). Dissolved-solids concentrations generally 1ncrease with increased time that water is in storage in the aquifer and in contact with the shales. 


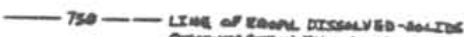

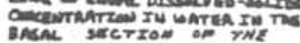

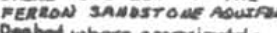

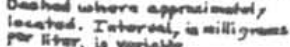

111015

EXPLANATION

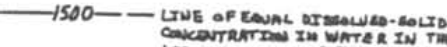

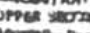

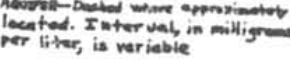

111915

- yell on tesr nowe

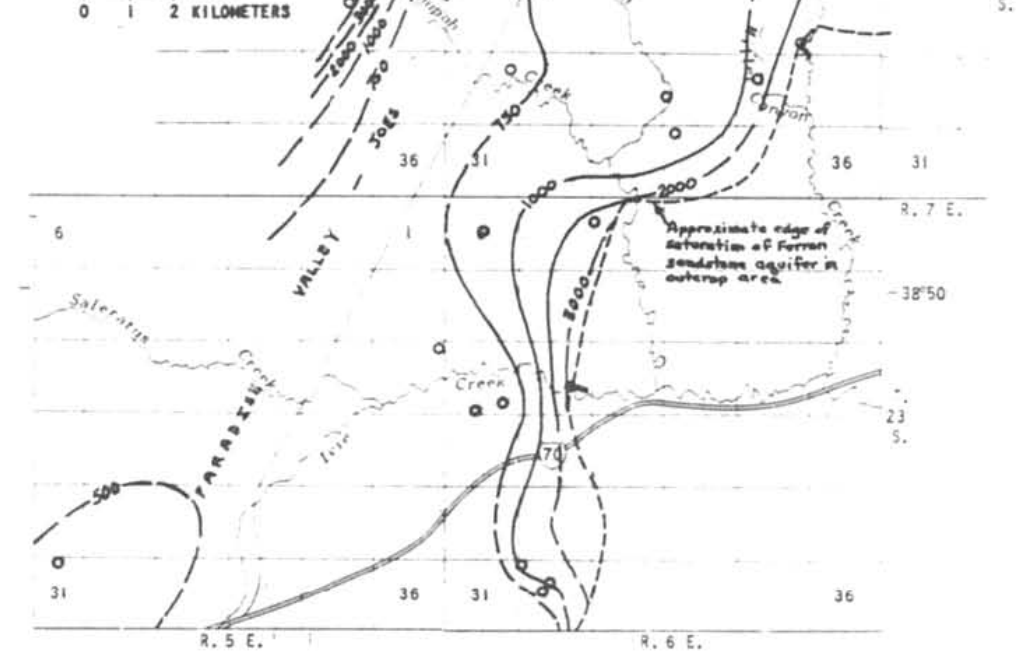

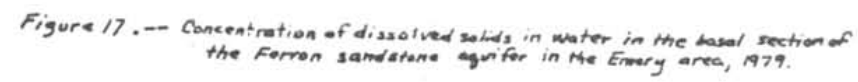


The largest observed concentration of dissolved solids in the upper section of the Ferron sandstone aquifer east of the Paradise Valley-Joes Va:ley fault system were in an area near the proposed surface mine, between the Emery Mine and the head of M11lc. Canyon. Dur1ng 1979 in this area, the vater table in the Blue Gate Member vas at a higher altitude than the potentiometric surface of the upper section of the Ferron. Water in the Blue Gate, which contained about $20,000 \mathrm{mg} / \mathrm{L}$. of dissolved solids, was leaking downvard 1nto the Ferron. The downward leakage of saline water from the Blue Gate in this area could be induced by natural discharge from the aquifer at the head of Miller Canyon, or it could be due to devatering of the Emery Mine.

From the configuration of the contours in figure 18, it can be inferred that the renoval of large quantities of water from the Emery Mine has improved water quality in the upper section of the Ferron between the mine and the fault system to the vest. Dewatering of the mine has accelerated the rate of water movenent toward the mine froa ail directions. The increased movement of less saline water from the west through the upper section of the aquifer, hovever, has more than off set any deterioration of water quality that may have been caused by increased downward leakage from the Blue Gate. Improvement in the quality of wates entering the mine also may be indicated by changes in dissolved-solids concentration in water pumped from the aine. Water collected in 1975 at the end of the mine discharge 1ine contained $5,100 \mathrm{mg} / \mathrm{L}$ of dissolved solids (Wadde11 and others, 1978, p. 15). Samples collected in February and September 1979 contained 4,780 and $3,040 \mathrm{mg} / \mathrm{L}$ of dissolved solids.
Data are lack.1ng to define vater quality in the Ferron sandstone aquifer in most areas west of the Paradise Valley-Joes Valley fault system. However, large dissolved-solids concentratiuns in water from test hole (D-22-5)23aca-1 indicate that vater quality in the Ferron deteriorates, at least in some areas, a short distance vest of the fault system. This is consistent with the hypothesis that most. If not all, of the vater moving from the Wasatch Plateau to the Ferron in the Emery area is transmitted along the highly permeable zone created by faulting.

The feu chemical analyses of water from the Ferron in the northern two-thirds of Castle Valley and adjacent wasatch Plateau (table 6) indicate that vater is generally of poorer quality than in sost of the Esery area. This is probably due to the increased distance from recharge areas and the increased time water is in contact with the rocks. Dissolved-solids concentrations in water in the Ferron in the northern two-thirds of Castle Valley usually exceed $3,000 \mathrm{mg} / \mathrm{t}$. Several vater samples obtained from test holes and gas vells in the Ferron contained more than $10,000 \mathrm{mg} / \mathrm{L}$ of chloride and more than $20,000 \mathrm{mg} / \mathrm{L}$ of dissolved solids.

\section{SURFACE WATER}

The northern end central parts of Castle Valley are drained by the Price and San Rafael Rivers, both of which are tributaries to the Green River. Three major tributaries to the San Rafael River (Huntington, Ferron, and Cottonwood Creeks) originate on the central Wasatch Placeau and cross Castle Valley and the outcrop of the Ferron Sandstone Member. The flows of these streams are diverted in Castle Valley for 1rrigation or municipal supply,

The southern part of Castle Valley is drained by tributaries to the Dirty Devil River, which is a tributary to the Colorado River. Three mafor tributaries to the D1rty Dev11 RIver that or1g1nate on the Wasatch Plateau and that cross the outcrop of the Ferron Sandstone Member are Muddy, Quitchupah, and Ivie Creeks. 
Quitchupah Creek and 1ts tributary Christlansen Wash are treated in deta11 in th1s report because they are near the proposed surface mine. Figure 19 shows

Figure 19 (caption on next page) near here

data-collection sites on these streams during 1978-79. For information on other surface waters in the area, the reader 1s referred to Mundorff (1972 and 1979) and Wadde11, Contratto, Sumsion, and Butler (1979).

$$
\text { Quantity }
$$

Quitchupah Creek has a drainage area of $104 \mathrm{mi}^{2}$ at gaging station 09331900 near the Emery Mine. The average dally discharge for vater year 1979, the first complete year of operation, was $6.7 \mathrm{ft}^{3} / \mathrm{s}$, ranging from a low of $1.1 \mathrm{ft}^{3} / \mathrm{s}$ on October $28-30,1978$, to a h1gh of $45 \mathrm{ft}^{3} / \mathrm{s}$ on November 2,1978 (U.S. Geological Survey, 1980, p. 290). During the summer months, flow at the staticn consists mainly of vater pumped frow the Emery Mine and return flow of 1rrigation water.

Christiansen Wash was gaged at station 09331950 during the 1979 water year. The drainage area at this station, a short distance downstrean from the proposed surface mine, is $13.6 \mathrm{ai}^{2}$. Dally discharge at the station averaged $2.8 \mathrm{ft}^{3} / \mathrm{s}$ during vater year 1979, ranging from $0.43 \mathrm{ft}^{3 / 3}$ on January 7 , 1979, to $20 \mathrm{ft}^{3} / \mathrm{s}$ on May 6 and 20, 1979 (U.S. Geological Survey, 1980, p. 294). The flow in Christiansen Wash is perennial at the gaging station, and streamilow is due mainly to return flow of irrigation water originally diverted from Muddy Creek. The upper reaches of Christiansen Wash, upstream from irrigated areas, flow only in response to snowmelt or thunderstorns. 10000

COWTINUOUS-RECORD ANGING STATIOW-Sfirs? two digits identifies stetion as being in the Colorodo Rive Btram and the six remaining kiver bosin relative downstrean digits ind kate

oIs DEMENURE MEUT SITE Letter by symbol indicates Ther types of data collectod

E, benthic invertebrates

C. thorganic chemical 3855

S, suspended sediment

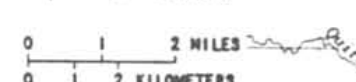
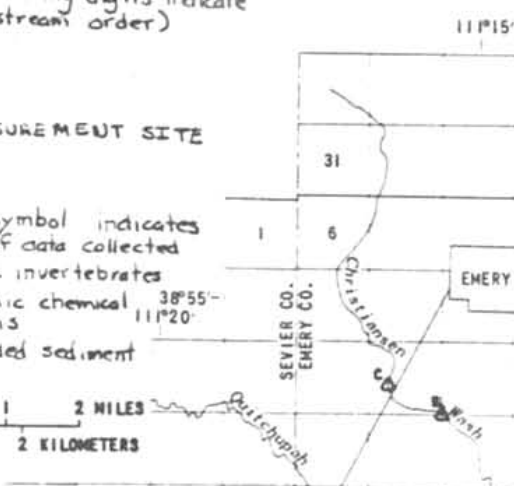

P15

\section{Thasey mange}

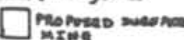

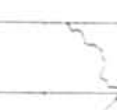

2

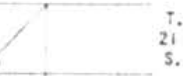

31 रे 31

Figure 19.--Location of data-collection sitos on Quiteh upah Creek and Christiansen Wash in the Emery area $1978-79$. 
Quality

Inorganic dissolved solids

Most surface vaters in Castle Valley deteriorate in chemical quality as they cross shales in the Blue Gate Member (Mundorff, 1979, p. 34). As previousiy. mentioned, the shales contain large quantities of soluble sodium and sulfate minerals. These ginerals are subject to solution by surface runoff and ground water.

Water in Quitchupah Creek deteriorates in chemical quality between State H1ghway 10 and the conf1uence with Christiansen Wash. At State Highway 10 , during 1975-76, the average concentration of dissolved solids in six water samples vas $950 \mathrm{mg} / \mathrm{L}$. The average concentration in s1x samples collected concurrently from Quitchupah Creek Just above the conflicence with Christiansen Wash vas $2,270 \mathrm{mg} / \mathrm{L}$ (Mundor $f f, 1979$, table 6). Th1s increase in dissolvedsolids concentration is due to increased concentrations of all the major cations and anions but mostly to an increase in sodium and sulfate. Inflow between the two sites mainly consisted of pumpage from the Emery Mine and return flow of irrigation vater.
Seasonal variation in the concentration of disvolved solids at the gaging station on Quitchupah Creek during the 1979 water year is 111ustraced in figure 20.

F1gure 20 (caption on next page) near here

Observed extremes of d1ssolved-solids concentrations were $696 \mathrm{mg} / \mathrm{L}$ on May 8,1979 , and $3,960 \mathrm{mg} / \mathrm{L}$ on November 19, 1978 (U.S. Geological Survey, 1980, p. 292). The trend during the 1979 vater year vas from greater discharge and lesser concentration of dissolved sc1ids during the spring-runoff period (April-June) to lesser discharge and greater coccentration of dissolved solids during the sumer and fall (July-November). During the vinter (December-March), discharge and concentration of dissolved solids generally were intermediate to those observed during the spring and sumer.

Areal variation in the concentration of dissolved solids along Christiansen Wash is slightly different than along Quitchupah Creek. The average concentration of dissolved solids in six sets of samples collected during 1975-76 at State Highuay 10 and at the mouth of Christiansen wash vere 3,670 and $2,610 \mathrm{mg} / \mathrm{L}$ (Mundorff, 1978, table 6), indicating a downstream decrease in the concentration of dissolved solids. Flow in Christiansen Wash at Stace Highway 10 is internittent and, with the exception of periods during thunderstoras and snowmelt, consists of seepage of irrigation vater that contains large concentrations of dissolved solids. A part of the flow of Christiansen wash at the south also consists of frrigation vater returned by ground-vater seepage, but the flov is also sustained by overland flow of 1rrigation water and water discharged from the Ferron sandstone aquifer. The mafor part of the flow at the mouth probably represents overland flow of Irrigation vater, which generally contains swaller concentrations of dissolved solids than does ground water that seeps into the Wash. 


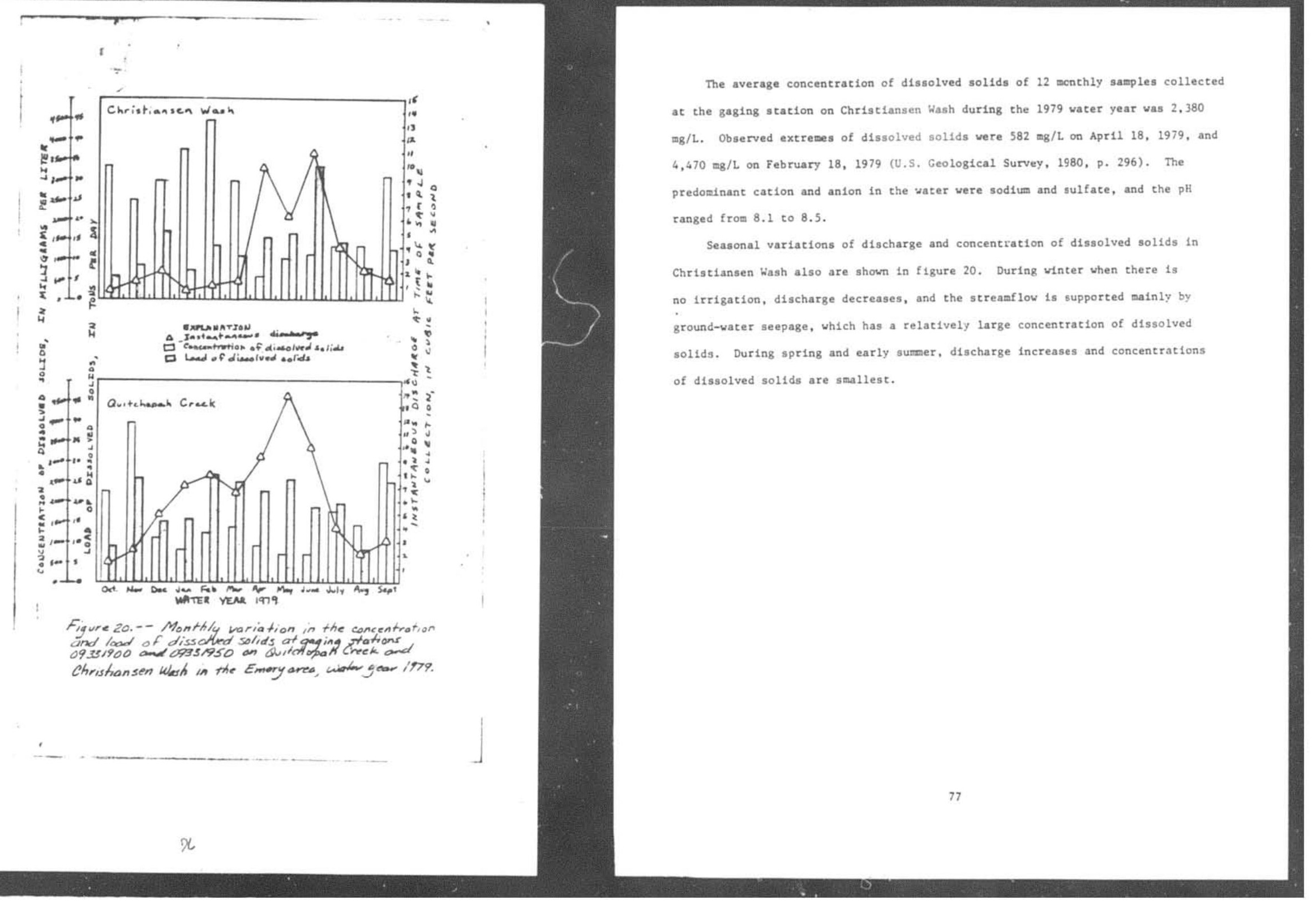


Suspended-sediment samples vere collected at the gaging stations on Christiansen Wash and Quitchupah Creek by the equal-d1scharge increment and equal-w1dth increment wethods (Guy and others, 1977, chap. 3). During August 2. 1978, to September 17, 1979, the observed suspended-sediment concentration at the gaging station on Quitchupah Creek ranged from 111 to $30,200 \mathrm{mg} / \mathrm{L}$. The relationship between suspended-sediment concentration and stream discharge at the Quitchupah station 1s shown in figure 21. As discharge increased, the

Figure 21 (caption on next page) near here

concentration of suspended sediment also increased. It is interesting to note that there is less scatter from the regression line at discharges above $5 \mathrm{ft}^{3} / \mathrm{s}$. The correlation coefficient for the regression line in figure 21 is 0.88 .

- Correlation coefficient is an estimate of the degree of interrelation between variables and is expressed in dimensionless units. A correlation of +1 indicates a perfect direct relationship between two variables; a correlation of -1 indicaces that one variable changes inversely with relation to the other. Between the two extremes is a spectrum of less-than-perfect relationships, Including zero, which indicates the lack of any sort of linear relationship

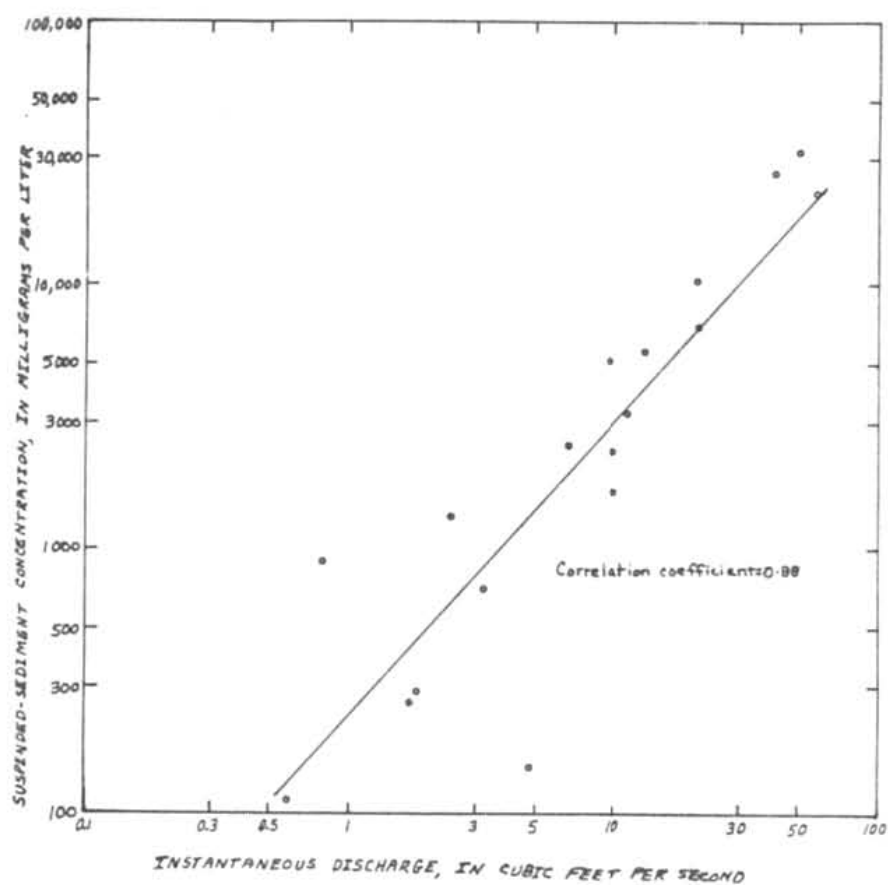

Figure 21.-- Relationship detween suspendad-sediment concentrotion Quitchupat Creek in the Emery area, Augost 1978 - Septembor 1979 
During May 25, 1978, to September 17, 1979, the observed suspended-sediment concentration at the gaging station on Christiansen Wash ranged from 3 to 4,870 mg/L. The relationship between suspended-sediment concentration and discharge at the Christiansen Wash station for discharges greater than $1 \mathrm{ft}^{3 / 3}$ is shown in f1gure 22. This relationship is not as well defined as at Quitchupah Creek. The

F1gure 22 (caption on next page) near here

regression line in figure 22, which applies to observed discharges that were greater than $1 \mathrm{ft}^{3} / \mathrm{s}$, has a correlation coefficient of 0.72 . The regression lines in figures 21 and 22 should not be used to estimate suspended-sediment concentrations for discharges outside the ranges that were sampled.

Sediment data at the gages oa Christiansen wash and Quitchupah Creek are Insufficient to determine sedisent yields from the basins. King and Mace (1953, p. 18) studied sedimentation in a number of small reservoirs in Castle Valley, and they found that the average annual sediment production varied from 0.3 acre- $\mathrm{ft} / \mathrm{m}^{2}$ in areas underlain by resistant sandstones like those in the Ferron Sandstone Member to about $2.6 \mathrm{acre}-\mathrm{ft} / \mathrm{m} 1^{2}$ in areas underla1n by shales like those in the Blue Gate Member. 


\section{Benthic invertebrates}

To deternine baseline cond1c1ons before surface mining occurs, benth1c invertebrates were sampled in Christiansen Wash and Quitchupah Creek at the eight locations shown in figure 19. Samples were taken in the sumer and fall of 1978 and in the spring, sumer, and fall of 1979. The samples were collected using a Surber sampler according to methods outlined by Greeson and others (1977, p. 171). Each sample represents those organisms collected from $3 \mathrm{ft}^{2}$ of stream botton in riffle areas. Table 7 is a 1isting of organisms identifled by phylogenetic order or family, the diversity index / by order, and the total wet

-According to Lium (1974, p. 382) "Diversity, or the evenness of distribution of insects, gives some indication of the environmental condition of a stream." Diversity was computed for each sample by order using the Shannon-We1ner approximation:

Diversity index $=-\sum P I \log _{2} P I$

where PI is the probability of occurrence of the $I^{\text {th }}$ order. The probability (PI) is equal to NI/NS, where NI is the number of individuals in each order and wS is the total number of individuals in i1 orders.

veight of organisas in each sample.
At the sites in Christiansen Wash, there were large seasonal and areal variations in the benthic-1nvertebrate population. However, 94 percent of all organisms collected were from the order Diptera (true flles), 4 percent from the order Trichoptera (caddis f11es), with the remining 2 percent composed of nine other orders. Of all organisms collected In Christiansen Wash, the families Chironomidae (aidges) and simuli1dae (black flies) represented 89 percent. This dominance of the benthic-invertebrate population by two families indicates an environment that does not support a varied population of organisms.

As in Christiansen Wash, there were also large seasonal and areal variations in the benthic-invertebrate population in Quitchupah Creek. For all samples collected on Quitchupah Creek, the order Diptera (true files) comprised 45 percent, Trichoptera (cadd1s flies) 30 percent, Ephemeroptera (mayflies) 13 percent, and Basommatophora (sna11s) 9 percent. The remaining 4 percent of the organisms were In an unknown order of aquatic worms and the orders Odonata (dragonf11es), Hemiptera (true bugs), and Acarina (water miros).

The population of organisms in Quitchupah Creek was more diverse than the population in Christiansen Wash. However, the total number of organisms collected in Quitchupah Creek in 11 samples was 1,291 compared to 18,026 organistas collected in 13 samples from Christiansen Wash. The reason for the differences in diversicy of organisms may be that a more varied habitat (pools, riffles, and variety of substrate material) exists in Quitchupah Creek. However, the greater sediment loads and scouring from spring floods prevents large numbers of organisms from becoulng established 1n Quitchupah Creek. Christ1ansen wash has a less var1ed habitat, but more stable overall conditions allow certain groups of organisms to become well established. 
Benthic 1nvertebrates collected during 1978-79 1ndicate that there are large seasonal var1ations in diversity and numbers of 1ndivioual organisms in Christiansen Wash and Quitchupah Creek. Additional samples are needed (particularly at the gaging station on Christiansen wash downstream from the proposed surface mine) to further define the natural seascnal variability and to detect changes in the benthic-invertebrate population that may occur because of surface mining. Members of the orders Ephemeroptera, Plecoptera, and Trichoptera are especially susceptible to damage from increased sediment (R. H. Fuller, U.S, Geological Survey, written commun., 1980). Changes in pH and dissolved solids (Including dissolved trace metals) associated with mining activities also have been shown to affict benthic invertebrates (Fuller and others, 1978, p. 22-27; Herricks and Cairns, 1973, p. 103).

\section{COMPUTER MODEL}

A three-dimensional digital-computer model was used to simulate ground-water flow in the Ferron sandstone aquifer in the Emery area. Approximately $60 \mathrm{mi}^{2}$ of the aquifer were modeled and the modeled area and grid used are show in figure 23.

Figure 23 (caption on next page) near here

The model also was used to predict the effects of dewatering the proposed surface mine on potentionetric suriaces and the base flow of streams. The model used for this study is documented by Trescott (1975) and Trescott and Larson (1976). Changes were made to the original Trescott-Larson three-dimensional model to allow simulation of leakage along streams $f$ rom all layers of the model. The design, construction, and calibration of the model are discussed in detail by Morrissey, Lines, and Bartholoma (1780).

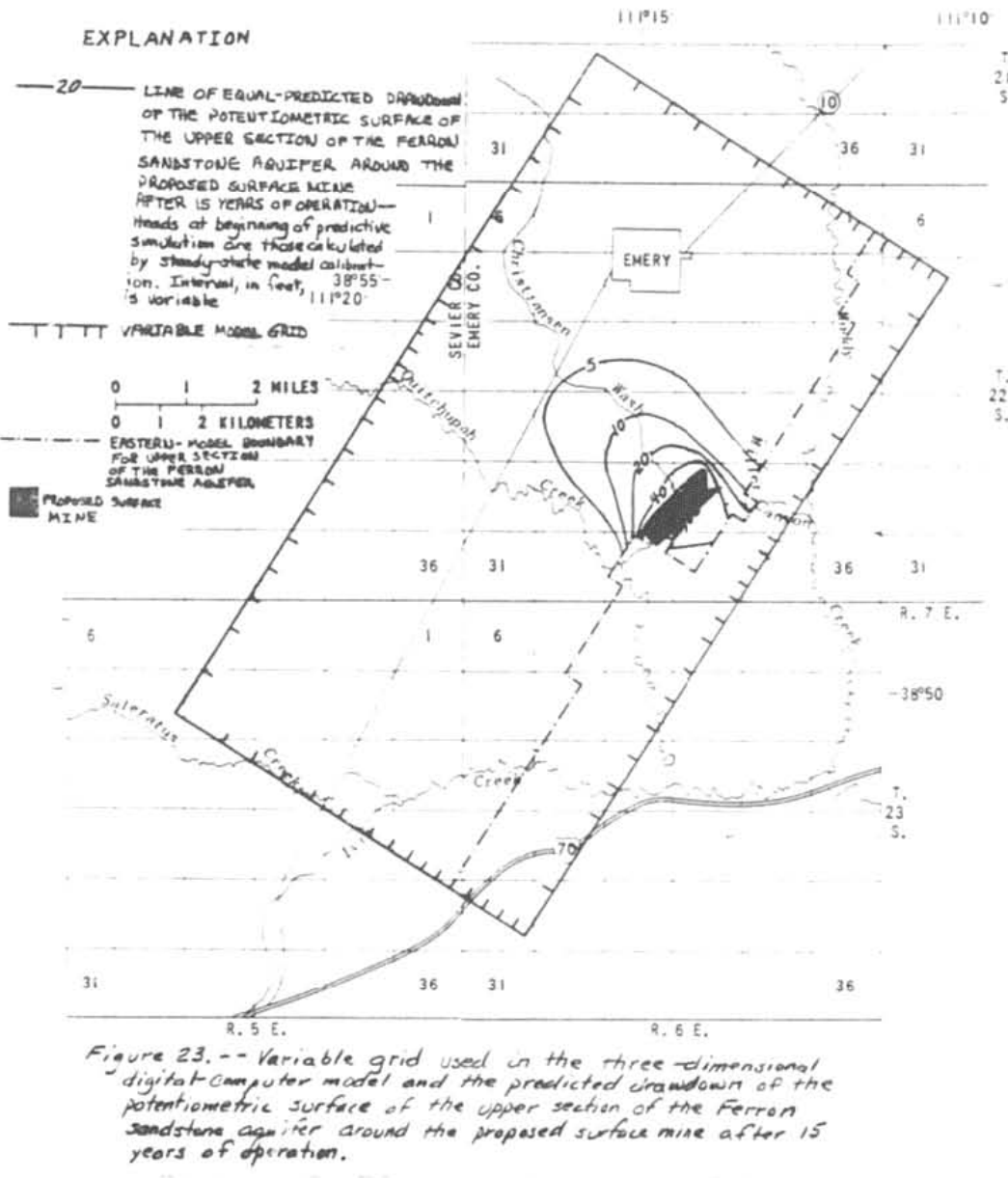


Assumptions and accuracy

Predictions ade with the model are corsidered to be semiquantitative for three reasons. The first reason is a lack of historical ground-water data in the modeled area, which results in an inability to verify the model with h1atorical data for aquifer response to manmade discharge. The second reason is the assuaption made in calibration of the model that the Ferron sandstone aquifer was in a steady-state condition during 1979. Although the aquifer vas not in a true steady-state condition, the assumption of steady state 1 s reasonable as water-level changes were only a fev feet in most wells during 1979. The third reason involves an assumption inherent in the model that flow in the aquifer is through pore spaces. Although in some areas fractures are the major conduits through which water flows through the Ferron, the aquifer can be modeled because on a large scale the system probably acts as a porous medium.

Despite these 11 miting assumptions, the model provides the rost realistic available method to analyze the effects of mine devatering on the aquifer. The alternative approach, using an analytical method of analysis, would require more simplifying assumptions than those associated with the model. Thus, results of an analytical method could be used with less confidence than those obtalned with the model.
Prediction

The calibrated model. was used to predict the effects of devatering the proposed surface sive on 1979 ground-water conditions. Transient and steady-state simulations of the proposed surface mine were made with the model. In simulating the surface mine, it was assiwed $t^{2} a t$ the pit would be dewatered, and this was simulated by constant-head nodes for lay... The model (the upper section of in the mine area. Tne cunstant-head nodes were held at the altitude of the base of the coal seam to be mined. Grid spacing did not pernit a precise sisulation of the "moving" pit, and an average mine location was simulated. Constant-head nodes a1so were used to simulate the underground Emery Mine during the predictive simulations.

Aquifer tests of confined parts of the Ferron sandstone aquifer indicate that the storage coefficient ranges from about $3 \times 1 \mathrm{C}^{-6}$ to $2 \times 10^{-3}$. During the transient-predictive simulation, a storage coefficient of $1 \times 10^{-4}$ was assigned to all layers of the Ferron where they vere confined efther by overlying shale or another layer of the Ferron. In areas where the aquifer was unconfined, a value of $5 \times 10^{-2}$ was assigned. Storage coef ficients for layers 1 and 5 (the shales in the Tununk and Blue Gate Members) vere not needed because these layers were sinulated by constant-head nodes.

To check the sensitivity of the model to variations in storage coefficient, two additional simulations were made. In one simulation, the storage coetfictents in confined areas were set at $1 \times 10^{-5}$ and in unconfined areas at $1 \times 10^{-2}$. In the second siaulation, storage coefficients vere set at $1 \times 10^{-3}$ in confined areas and at $1 \times 10^{-1}$ in unconfined areas. The results of these two simulations, as compared with results of the transient-predictive simulation, show that variations in storage do not seriously affect model predictions. Differences in calculated drawdowns at most nodes near the surface mine vere less than 1 foot when using the different storage coefficients. 
Results of predictive model simulations indicate that dewatering of the proposed surface mine will affect potentiometric surfaces of all layers of the Ferron sandstone aquifer, hovever, predicted drawdowns along model boundaries would be less than 4 feet. The predicted drawdowns in potentiometric surfaces and the effects on the base flow of streams are discussed in detail in following sections of thie report.

EFFECTS OF PROPOSED SURFACE MINING

$$
\text { Mining plans }
$$

In March 1976, appilcation was filed with the 011, Gas and Mining Division of the Utah Department of Natural Resources for a surface-coal mine in the Emery Coal Field. The proposed surface mine would be in the drainage of Christiansen Wash ( $f 1 g .23$ ) near the existing underground Emery Mine. Approximately 430 acres would be directly disturbed by the mining operation. Coal would be mined from the I- and J-coal seams in the Ferron Sandstone Member. Surface mining would begin along Christiansen wash in the area shown in ftisure 24 , where the coal is at the surface. The mining would proceed in 10

Figure 24 (caption on next page) near here

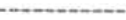

strips to the northwest until an unecononical depth was reached, about 110 feet according to the mining application. Mining would terminate on the Blue Gate Member in areas like that shown in figure 25 . The mine would have a life

Figure 25 (cap:ion on next page) near here

$+\cdots$

of about 15 years. There has been no surface mining in the Emery Coal Field through 1980.

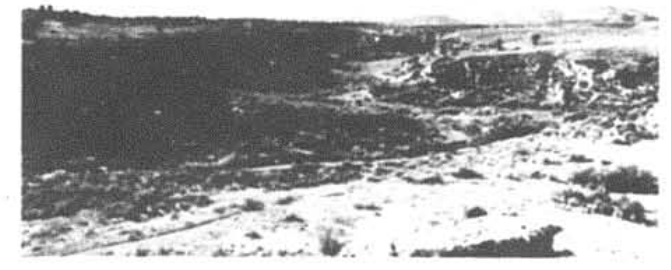

Figure 24.--Area of proposed surface mine along Christiansen Wash. Ferron Sandstone Member of the Mancos Shale crops out along edges of floodplain; greasewood grows on alluvium along stream. 
The proposed mining sequence is as follows: (1) construction of mine access roads and surface facilities, (2) removal and storage of surface material (soil), (3) drilling and blasting of overburden, (4) removal of overburden, (5) removal of coal, (6) grading of spoll overburden, (7) replacement of so11, and (8) revegetation.

Overburden from each successive mine cut would be placed in the previously ained cut or on adjacent land not to be mined. Grading of the spoil overburden, replacement of soils, and revegetation would occur simultaneously with the mining operation. Maximum slope of land surface in the reclaimed mine area would be 18 percent and would occur along the final mine highwall.

According to the mining application, Ciristiansen wash would be diverted around the northwest side of the mine. A diversion ditch also would be installed along the southeast side of the gine area to intercept and divert surface runoff from the Ferron outcrop into Christiansen wash below the aine.

$$
\begin{aligned}
& \text { Mine dewatering } \\
& \text { Effects on ground water }
\end{aligned}
$$

F1gure 25.--Sparsely vegetated surface of the Blue Gate Member of the Mancos Shale that is typical of area where proposed surface mining will terminate. Christiansen Wash and outcrop of the Ferron Sandstone Member of the Mancos Shale in background. aquifer was used to evaluate the effects of dewatering the proposed surface mine on the aquifer. As pointed out earlier, predictions made with the rode! are considered to be semiquantitative.

Discharge from the surface mine 1 s predicted to average about $0.3 \mathrm{ft} 3 / \mathrm{s}$ during the proposed 15 years of operation. Model calculations indicate that water discharged from the surface mine would be balanced by a decrease in storage in the Ferron sandstone aquifer, by a decrease in vater entering the underground Fmery Mine, by a decrease in natural leakage from the aquifer, and by an Increase in leakage to the aquifer from the slue Gate Member. 
The predicted dravdown in the potentiometric surface of the upper section of the Ferron sandstone aquifer (the section in which surface aining is proposed) after 15 years of aine devatering is shown in figure 23 . It is predicted that draudowns greater than 5 feet in the upper section of the aquifer would extend about 2.5 alles from the aine. Other sections of the Ferron sandatone aquifer also would be affected, but drawdowns would not be as great. In the basal section of the aquifer, it is predicted that drawdo ns greater than 5 feet would extend about 2 miles from the proposed mine, and drawdowns greater than 10 feet would extend about 0.25 wile from the mine.

Model calculations indicate that dewatering of the surface mine vould increase downward leakage Into the Ferron sandstone aquifer from the Blue Gate Yember by about $0.05 \mathrm{ft}^{3} / \mathrm{s}$; practically all (98 percent) of this increase would occur within the area of draudown greater than 5 feet shown in figure 23. Water in the Blue Gate contained about $20,000 \mathrm{mg} / \mathrm{L}$ dissolved solids, and the dissolved-solids concentration of water in the upper section of the Ferron ranged from about 1,000 to $3,000 \mathrm{mg} / \mathrm{L}$ in the affected area during 1979 . Thus, the additional domward leakage of vater from the Blue Gate might cause deterioration of vater quality in the upper section of the Ferron in sone areas.
As discussed earlier, dewatering of the underground Enery Mine aight have caused deterioration of water quality in the upper section of the Ferron sandstone aquifer in the area between the aine and the head of Miller Canyon. Dewatering of the surface mine might further deteriorate vater quality in the upper section of the aquifer in the area between the surface mine and the canyon. However, as near the underground mine, vater quality in the upper section of the aquifer might not deteriorate in other areas. The increased movement of less saline water through the aquifer toward the surface mine from the vest might more than offset any deterioration that would be caused by increased leakage from the overlying Blue Gate Member vest of the mine.

The predicted effects of dewatering of the surface mine on potentiometric surfaces and water quality in the Ferron are based upon conditions that existed in 1979. Ground-water conditions in the Ferron could be changed, however, by increased withdrawals from wells and from the underground Emery Mine. If groundwater conditions vere significantly different during the surface mining, the effects of mining on the ground-vater system would be different than those predicted. Effects on surface vater

Modeling results Indicate that, except for Christiansen wash, the devatering of the proposed surface mine would not af fect the base flow of streams. If water iroe the aine were discharged fnto Christiansen Wash, streamfiow would increase accordingly. The predicted mine discharge $\left(0.3 \mathrm{ft}^{3} / \mathrm{s}\right)$ would be almost equal to the minisum observed discharge on Christiansen wash during the 1979 water year. 
Dissolved-solids concentrations in water in the upper section of the Ferron sandstone aquifer ranged from about 1,000 to $8,000 \mathrm{mg} / \mathrm{L}$ in the surface-mine area during 1979, and water in the Blue Gate Membar contalned about $20,000 \mathrm{mg} / \mathrm{L}$ of dissolved solids. The vater entering the surface mine would be a mixture of these two waters and water that would drain from the disturbed overburden. Chemical quality of the mine water would vary with time and would probably have a dissolved-solids concentration within a range of 2,000 to $1 \mathrm{l} .000 \mathrm{mg} / \mathrm{L}$. The average dissolved-solids concentration of 12 monthly samples taken at the gaging station on Christiansen wash below the mine area during the 1979 water year was $2,380 \mathrm{mg} / \mathrm{L}$, and the concentration ranged from 582 to $4,470 \mathrm{mg} / \mathrm{L}$. Thus, at least during some periods, the dissolved-solids concentration of water in Christiansen Wash would be increased if mine water were discharged fnto the stream.

$$
\text { Leaching of overburden }
$$

In the process of mining at the proposed 430-acre surface site, approx1mately 25,800 acre-feet $(41,600,000$ cubic vards) of overburden would be displaced. based on an average overburden thickness of 60 feet. The overburden would be highly fractured during the mining procesn: thus, it would be a readily avallable source of material that could be leached by surface water, ground water, and precipitation. In order to estimate the possible effects of leaching of overburden during the mining operation, laboratory leaching studies were carried out.
Cores of representative overburden were obtained from test holes. In the laboratory experiments, 100 grans of core material (table 3), wh1ch had been

Table 3 (next page) near here

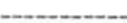

crushed to less than 0.25 inch in size, were placed in a 1-11ter erlenmever flask with 750 milliliters of defonized water (similiar to rainfall and snowme1t) and shaken at room temperature. Samples were shaken from 12 to 26 weeks until the $\mathrm{pH}$ and specific conductance of the solution remained constant. Core material within the flasks had abraded to sand and clay sizes by the end of the equilibration period. These equilibration experiments showed the composition of leachate under oxidizing conditions (table 4). No attempt was made to simuiate leaching under

Table 4 (next page) near here

reducing conditions. 
The results of the equilibration experiments (table 4) 1ndicate vater of better shemical quality than had been expected, especially when compared with many of the ground-water analyses reported in table 6 . The dissolved solids of the equilibrated samples ranged from 539 to $2,556 \mathrm{mg} / \mathrm{L}$, with a mean concentration of $1,160 \mathrm{mg} / \mathrm{L}$. The equilibrated samples were of the calclum sulfate water type, with the exception of samples $4 \hat{A}-6,4 \hat{A}-7$, and 5-11, which were mixed calcium and magnesium sulfate vaters, and sample $3-10$, which was a sodium sulfate water. The mafor constituents found in the equilibration leachate are attributed to the alteration and solution of soluble salts such as mirabilite $\left(\mathrm{Na}_{2} \mathrm{SO}_{4} \cdot 10 \mathrm{H}_{2} \mathrm{O}\right)$. thenardite $\left(\mathrm{Na}_{2} \mathrm{SO}_{4}\right)$, and gypsum $\left(\mathrm{CaSO}_{4} \cdot 2 \mathrm{H}_{2} \mathrm{O}\right)$, which have been reported to be in large quantities in the Mancos Shale (Waddell and others, 1979, p. 17). These minerals and pyrite and calcite all vere common in the core samples. These minerals, with the exception of pyrite, are of a sodium or calcium sulfate composition; and this is reflected in the composition of the leachate. A detailed study of the chemical composition of the Ferron Sandstone Member and associated coal beds in the study area is given by Affolter, Hatch, and Ryer (1979).
The leachates contained relatively los concentrations of trace elements (table 4). Iron concentrations vere unusuelly high in samples $3-2$ and $4 \mathrm{~A}-6$, however, with concentrations of 61,000 and $7,000 \mu \mathrm{g} / \mathrm{L}$. This is attributec to the pyrite that was noted in both samples and vas reflected in pH values of 4.0 and 3.8. Mixing pyritic material with calcareous

material in mine-spoil placement would reduce iron mobilization and acid production. Aside f tum the tws samples with large fron concentrations, trace elements in the leachates were found in quantitles that vould not be considered toxic to man, animals, or plants.

The concentration of dissolved solids in the leachates were considerably lower than in many of the ground-water samplea taken during the course of the study. Three possible reasons for this are:

1. The short period of contact time (12 to 26 weeks) in the case of the equilibrated samples compared to years in the case of much of the ground water.

2. Sose minerals, especialiy halite (NaC1), are found in the Mancos Shate but were not present in appreciable quantities in the cores. Halite mav account for much of the sodium and chloride found in some of the groundwater samples.

3. The equilibration experiments did not attempt to simulate reducing conditions or bacterial activity which undoubtediy have a significant influence on the solution of some minerals, especially pyrite and some of the sulfate minerals. 
The equilibration studies indicate that the water in the aine spoil would be of a chemical quality that is better than wuch of the ground water in the mine area and about the same quality as water in Christ'ansen Wash. Th1s would be the case if the vater table vere below the base of the spoil and if precipitation were the only water allowed to infiltrate the spoil. If surface or ground yater is allowed to infiltrate the spoil, the resulting vater quality would be worse than indicated by the equilibration studies because minerals dissolved from the spoil would add to the original concentrations in the int filtrating water.

\section{Erosion of overburden}

Weather conditions during and after surface aining wou'd Influence both the success of land reclamation and the amount of sediment eroded from the disturbed area. It is not possible to predict the weather with sufficient precision to predict sediment yield from the proposed mine area. However, it is possible to 1dentify those elements of mining and reclamation operations that are most 11kely to affect sediment yield and to identify environmental safeguards most tikely to gininize the impact.

There are many environmental safeguards in regulations implementing public Law 95-87. the Surface Mining Control and Reclamation Act of 1977 (U.S. Nfftce of Surface Mining Reclamation and Enforcement, 1979). Many of the safeguards are designed to prevent additional contributions of sediment to streams outside the wine area. The regulations require that the smallest possible area ar any one time be disturbed by mining operations and that there be progressive backfilling, grading, and prompt revegetation.
Probably the most important safeguard to minimize sediment loads downstream from the disturbed area is the ise of sediment ponds. The ponds are required to be as near as possible donnstream from the disturbed area, and they zust be able to store the runoff resulting from the 10-year maximum 24-hour precipitation. Ponds must retain this flow for at least 10 hours. In the Emery area, the 10-year maximum 24-hour precipitation is about 1.7 inches (Miller and others, 1973, p. 37) The ponds also are requited to store at a minimum the sediment that accumulates in 3 years from the drainage area, or a minimum of 0.035 acre-foos of sediment for each acre of disturbed area.

King and Mace (1953, table 6) found that basins in Castle Valley, which are sparsely vegetated and are underlain by shale and sandstone like those in the proposed surface-aine area, have annual sediment yields that normally range from 0.3 to 2.5 acre- $f t / m i^{2}$. Sediment loads of streams downstream from the mine area would not increase significantiy if slopes were graded to the least possible angle. If revegetation were prompt so as to stabilize the stockpiled topsoil and backfilled overburden, and if runoff were channeled from the disturbed area through the sediment ponds. The long-term sediment yield from the disturbed area could actually decrease if vegetative cover were improved from premining conditions and sediment ponds were properly maintained. 
Long-tera sedisent yields could also be minimized by permanantly diverting Christiansen Wash and runof $t$ from siopes southeast of the mine around the reclaimed area. Regulations for Public Law 95-87 require that natural riparian vegetation be enhanced or maintained along a permanent diversion and that the natural meandering shape and an acceptable gradient be established. Aquatic habitats, such as a pattern of riffies, pools, and drops, that approximate prealning characteristics could also be established along the diversion of Christiansen Wash. Hovever, until vegetation is established along diversions and until diversion channels have stabilized, erosion along the diversion channels would probably greatiy increase sediment yield. Etusion along the freshly cut channels could be minimized by channel lining. Here again, impact on streams downstream from the mine area could be held to a minimum by channeling the diverted vaters to properly constructed and maintained sediment ponds. NEED FOR FUTURE STUDY

An observation-well network needs to beestablished in the Emery area for the semiannual measurement of water levels in three or four wells that tap each section of the Ferron sandstone aquifer and the overlying Blue Gate Member. The vells also need to be sampled annually to detect possible changes in water quality. D1scharge from the Emery municipal ve11, the underground Emery Mine, and the surface aine (when operationa1) needs to be monitored. After approximately 5 years, the additional data can be used to recalibrate and verify the three-dimensional d1gital-computer model of the aquifer.
SUMARY

The largeat quantities of water are available from the Ferron sandstone aquifer in the Emery area vithin about 2 miles of the Paradise Valley-Joes Valley fault system. Wells that fully penetrate the aquifer in this area could be expected to produce 100 to $500 \mathrm{gal} / \mathrm{min}$ if pumped. Elsewhere the avallability of water from the Ferron is not as great, and in the northern two-thirds of castle Valley the aquifer probably would not y1eld more than about $10 \mathrm{gal} / \mathrm{min}$ to individual vells. The chemical quality of water in the Ferron varies both with depth in the aquifer and areally. Fully penetrating wells near the fault system in the Emery area would yield water with concentrations of dissolved solids

less than $1,000 \mathrm{mg} / \mathrm{L}$. In the northern part of Castle Valley, the concentration of dissolved solids in water from the Ferron probably would exceed 3,000 $m / / \mathrm{L}$ and could exceed $20,000 \mathrm{mg} / \mathrm{L}$.

Simulations using the model of the Ferron sandstone aquifer in the Emery area indicate that dewatering of the proposed surface mine wouit average about $0.3 \mathrm{ft}^{3} / \mathrm{s}$ during the 15 years of operation. Dewatering of the mine would affect the potentiometric surfaces of all sections of the aquifer. The maximum drawdown would occur in the upper section of the aquifer, and drawdowns greater than 5 feet would extend about 2.5 miles from the mine. Downward leakage of poor quality water from the shale in the Blue Gate Merber would sa induced near the mine, and vater quality in the upper section of the Ferron could deteriorate in some areas. 
Except for Christiansen Wash, dewatering of the surface aine would not affect the base flow of streams. If water from the mine were discharged into Christiansen Wash, the streamflow would increase accordingly. Chenical analyses of ground vater in the mine area and leaching experiments indicate that the chenical quality of water produced in the mine would vary. Concentrations of dissolved solids in the mine water should range from 2,000 to $10,000 \mathrm{mg} / \mathrm{L}$. If the mine water is discharged into Christiansen Wash, the dissolved solids in the stream water would be increased above premining concentrations, at least during some periods.

With proper reclamation practices and the use and maintenance of sediment ponds downstream from the mine area, there should be no significant increase in the sediment load of Christiansen Wash. Long-term sediment yield from the disturbed area could decrease if vegetative cover on reclaimed lands is improved from premining conditions and Christiansen Wash is permanently diverted around the mine area.
REFEREACES CITED

Affolter, R. H., Hatch, J, R., and Ryer, T. A., 1979, Chemical analyses of coal and shale from the Ferron Sandstone Member of the Mencos Shale, Emery coal fleld, Emery County, Utah: U.S. Geological Survey Open-File Report $79-858,35 \mathrm{p}$.

Cotter, E., 1975a, Late Cretaceous sețmentation in a low-energy coastal zone: The Ferron Sandstone in Utah: Journal of Sedisentary Petrology, v. 45, p. 669-685.

1975b, Delta1c deposits in the upper Cretaceous Ferron Sandstone of Utah, In Broussard, M. L., ed., Deltas, models for exploration: Houston Geological Soc1ety, Houston, Texas, p. 471-484.

1976, The role of deltas in the evolution of the Ferron Sandstone and 1ts coal: Brigham Young Un1versity Geology Studies, v. 22, part 3, p. 15-41. Criddle, w. D., Harris, Kar1, and willardson, L. S., 1962, Consumptive use and water requirements for Utah: Utah State Engineer Techn1cal Publication 8 , 47 p.

Davis, L. J., 1954, Stratigraphy of the Ferron Sandstone: Intermountain Association of Petroleum Geologists, Sth Annual Fleld Conference Guidebook, p. 55-58. Doelling, H. H., 1972, Central Utah coal fields: Utah Geological and Mineralogical Survey Monograph 3, $571 \mathrm{p}$.

Feltis, R. D., 1966, Water from bedrock in the Colorado Plateau of Utah: Utah State Engineer Technical Publication 15, 82 p.

Fuller, R. H., Shay, J. M., Ferreira, R. F., and Hoffman, R. J., 1978, An evaluation of problems arising from acid mine drairage in the vicinity of Shasta Lake, Shasta County, Californ1a: U.S. Geological Survey Water-Resources Investigations $78-32,39 \mathrm{p}$. 
Geoscient1f1c Systems and Consulting, 1979, Reclaimability analysis of the Emery coal field, Emery County, Utah: U.S. Bureau of Land Management, Energy Minerals Rehabilitation Inventory and Analysis Report 16, 408 p.

Greeson, P. E., chm., and others, 1977, Methods for collection and analysis

of aquat1c blological and microblological samples: U.S. Geological Survey Techniques of Water-Resources Investigations, book 5, chap. A4, $332 \mathrm{p}$.

Guy, в. P., chm., and others, 1977, National handbook of recommended methods for water-data acquisition, chapter 3 (sediment): U.S. Geological Survey Office of Water Data Coordination, 100 p.

Hale, L. A., 1972, Depositional history of the Ferron Formation, central Utah, in Plateau-Basin and Range transition zone, central Utah: Utah Geological Association Publication 2, p. 29-40.

Hatch, J. R., Affolter, R. H., and Law, B. E., 1979, Chemical analyses of coal from the Emery and Ferron Sandstone Members of the Mancos Shale, Henry Mountains field, Wayne and Garfield Counties, Utah: U.S. Geological Survey Open-File Report 79-1097, 24 p.

Herricks, E. E., and Ca1rns, J., Jr., 1973, Rehabilitation of streams receiving acid mine drainage: Virginia Water Resources Center Bulletin 66, 284 p.

Hood, J. W. and Dantelson, T. W., 1979, Bedrock aquifers in the lower Dirty Devil River basin area, Utah, with special emphasis on the Navajo Sandstone: U.S. Geologicai Survey Cpen-File Report 79-1163, 85 p.

Johnson, A. I., 1967, Specific y1eld--c smpilation of spec1fic y1elds for various materials: U.S. Geological Survey Water-Supply Paper 1662-D, 74 p.

Katich, P. J., 1951, The stratigraphy and paleontology of the pre-Niobrara Upper Cretaceous rocks of Castle Valley, Utah: Unpublished Ph.D. dissertation, Ohio State University, 208 p.
Katich, P. J., 1953, Source direction of Ferron Sandstone in Utah: American Association of Petroleum Geologists Bulletin, v. 37, p. 858-862.

1954, Cretaceous and Early Tert1ary stratigraphy of central and southcentral Uteh, with emphasis on the Wasatch Plateau area: Intermountain Association of Petroleum Geologists, 5th Annual Field Conference Guidebook, p. $42-54$.

King, N. J., and Mace, M. M., 1953, Sedimentation in small reservoirs on the San Rafael Swe11, Utah: U.S. Geological Survey Circular 256, 21 p.

Lium, B. W., 1974, Some aspects of aquatic insect populations of pools and riffles In gravel bed streams in Western Un1ted States: U.S. Geological Survey Journal of Research, v. 2, no. 3, p. 279-384.

Lohman, S. W., 1972, Ground-vater hydraulics: v.S. Geological Survey Professtonal Paper 708, $70 \mathrm{p}$.

Lohman, S. W., and others, 1972, Definition of selected ground-vater terms-revisions and concaptuai refinements: U.S. Geological Survey Water-Supply Paper 1988, $21 \mathrm{p}$.

Lupton, C. T., 1916, Geology and coal resources of Castle Valley in Carbon, Emery, and Sevier Count1es, Utah: U.S. Geological Survey Bulletin 628, 88 p.

Mi11er, J. R., Frederick, R. H., and Tracey, R. J., 1973, Precipitation frequency atlas of the Western United States--Utah: National Oceanic and Atmospheric Administration Atlas 2, v, 6, 67 p,

Morrissey, D. J., Lines, G. C., and Bartholome, S. D., 1980, Three-dimensional digital-computer model of the Ferron sandstone aquifer near Emery, Utah: v.S. Geological Survey Water-Resources Invest1gations 80-62, p. 101. Mundorff, J. C., 1972, Reconnaissance of chemical quality of surface water and fluvial sediment in the Price River basin, Utah: Utah Department of Natural Resources Technical Publication 39, 55 p. 
Mundorff, J. C., 1979, Reconnaissance of chenical quality of surface water and fluvial sediment in the D1rty Devil River basin, Utah: Utah Department of Natural Resources Technical Pub1lication 65, 132 p.

Pettifohn, F. J., [1957], Sedimentary rocks (2d ed.): New York, Harper and Brothers, $718 \mathrm{p}$.

Stokes, w. L., ed., 1964, Geolog1c map of Utah: Un1vers1ty of Utah, scale 1:250,000. Sums1on, C. T., 1979, Selected coal-related ground-water data, Wasatch Plateau-

Book Cliffs area, Utah: U.S. Geological Survey Open-File Report 79-915

(duplicated as Utah Basic-Data Report 32), 25 p.

Thatcher, L. L., Janzer, v. J., and Edwards, K. W., 1977, Methods for determination of radioactive substances in water and fluvial sediments: U.S. Geological Survey Techniques of Water-Resources Investigations, book 5, chap. A., 95 p.

Trescott, P. C., 1975, Documentation of finite-difference model for simulation

of three-dimensional ground-water flow: U.S. Geological Survey Open-File Report $75-438,32 \mathrm{p}$.

Trescott, P. C., and Larson, S. P., 1976, Documentation of f1nite-d1fference mode 1 fnr simulation of three-dimenstest ground-water flow, supplement to OpenFile Report 75-438: U.S. Geological Survey Open-File Report 76-591, 21 p.

U.S. Geological Survey, 1980, Water Resources data for Utah, water year 1979: Water-Data Report UT-79-1, $604 \mathrm{p}$.

U.S. Office of Surface Min1ng Reclamation and Enforcement, 1979, Surface coal mining and reclamation operations, permanent regulatory program: Federu1 Reg1ster, v. 44, no. 50, March 13, 1979, book 3, p. 15311-15463.

U.S. Weather Bureau, [1963], Nornal annual and May-September precipitation (1931-60) for the State of Utah: Map of Utah, scale 1:500,000.

Wadde11, K. M., Contratto, P. K., Sumsion, C. T., and But1er, J. R., 1979, Hydrologic reconnaissance of Wasatch Plateau-Book Cliffs coal-fields area, Utah: U.S. Geological Survey Open-File Report 79-988, 85 p. (to be duplicated as Water-Supply Paper 2068).
Wadde11, R. M., Vickers, H. L., Upton, R. T., and Contratto, P. K., 1978, Selected hydrologic data, 1931-77, Wasatch Plateau-Book C11ffs coal-f1elds area, Utah: U.S. Geological Survey Open-F1le Report 78-121 (duplicated as Utah Basic-Data Re1ease 31), 33 p.

Will1ams, P L., and Hackman, R. J., 1971, Geology, structure, and uranium deposits of the Salina Quadrang1e, Utah: U.S. Geological Survey M1scellaneous Geologic Investigations Map I-591, scale 1:250,000, 2 sheets.

Witkind, I. J., 1979, Reconnalssance geologic map of the Hellington Quadrangle, Carbon County, Utah: U.S. Geological Survey M1scellaneous Investigations Map I-1178, scale $1: 24,000$ 
Table 1.- Laboratory determinations of porosity, hydraulic conductivity, and grain size of rock sampler from the Ferron Sandstore nemiber of the Mancos stwle. (Determinations by Core Labopotories, Tone., Dallos, Texas).

Lithology: S, sandstone; SH, shale; SLT, siltstone; $a$, a thered by coal burn; d, delta-front; $f$, fluviatile; m, marine; $w$, weathered.

Sorting coefficient: $\sqrt{Q_{3} / Q_{1}}$, where $Q_{3}$ is the size where 25 percent of the grains are larger

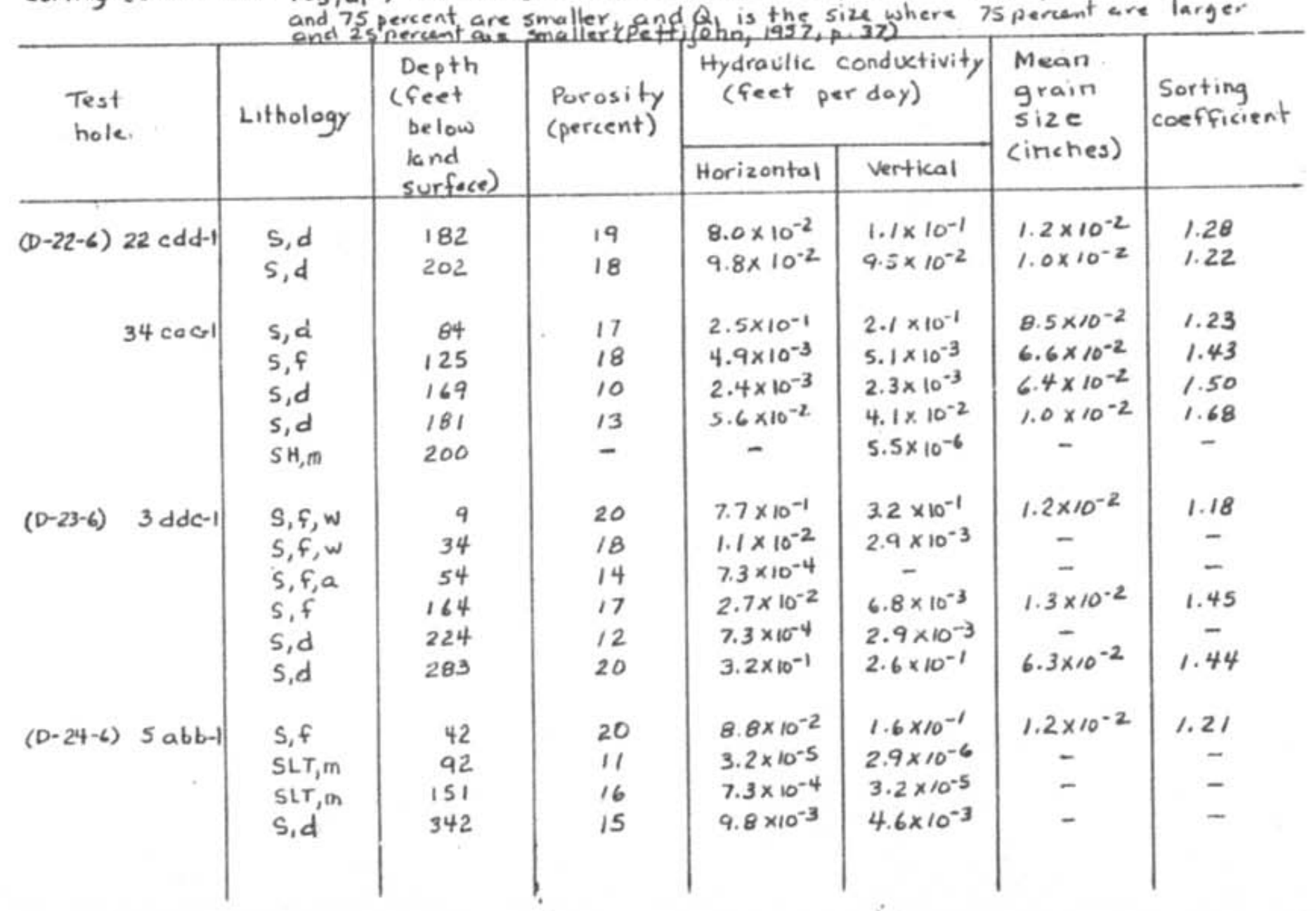


Table 2.-- Summary of aguifer tests conducted on the ferron sandstone aquifer in the Emery area, $1970-q$.

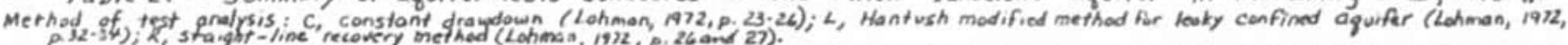

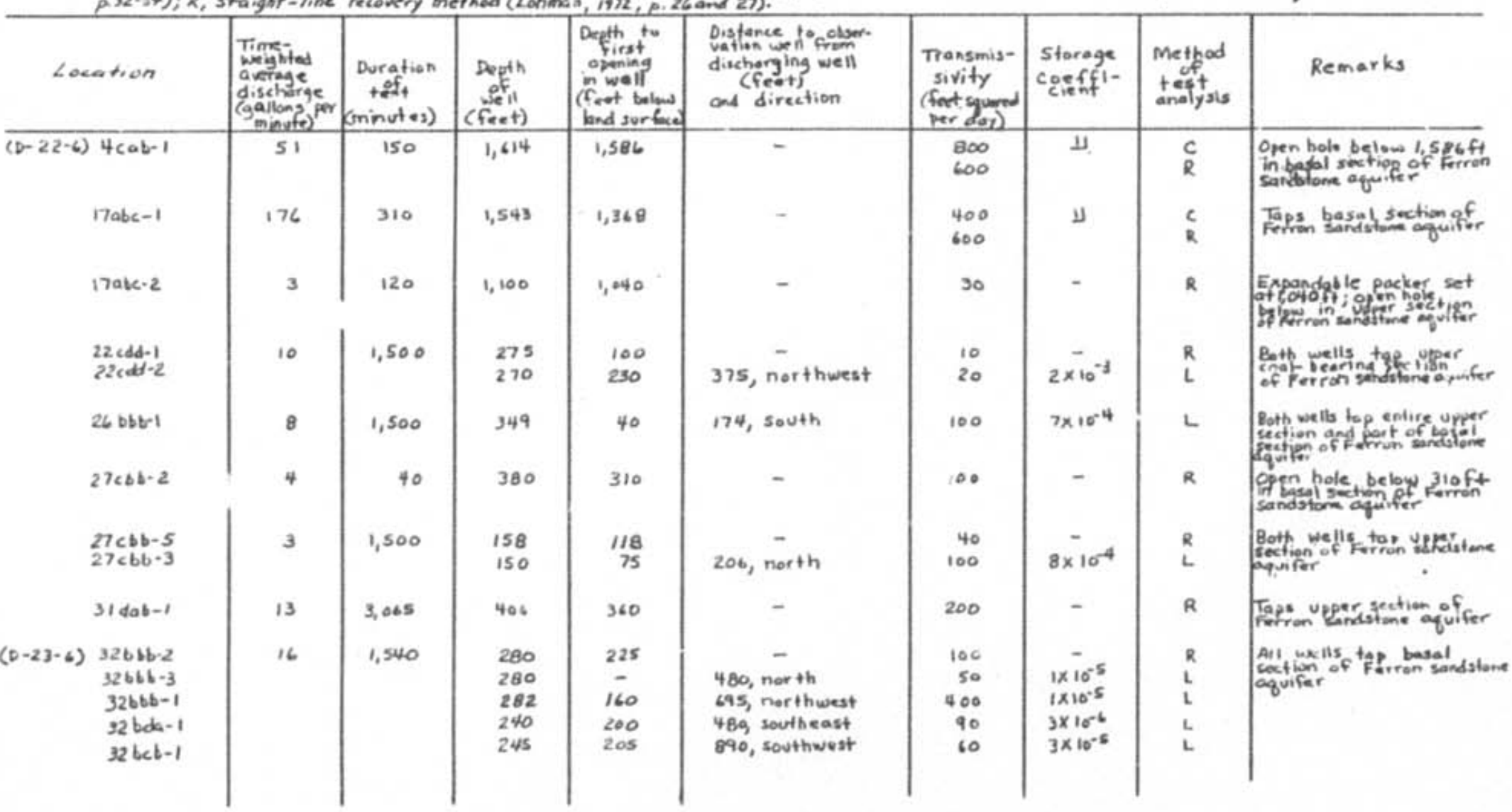


Table S.-. Reconds of selected wells, test noles, and sporngs in the Castle Valky arre.

Locatich: Seedexription of well- and spring-numbering systent.

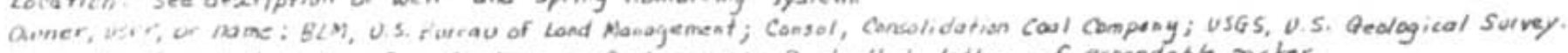

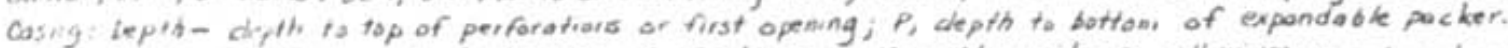

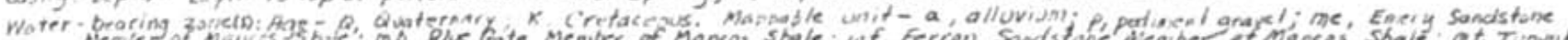

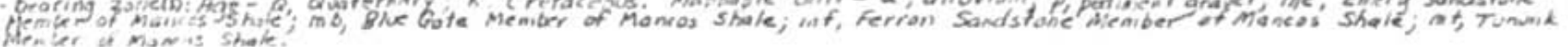

Albtive of laid-sieflace datium : Interpolated from topagraphe mas.

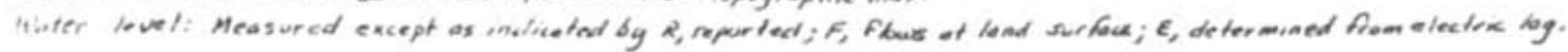

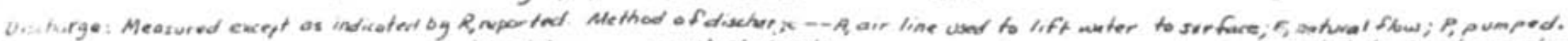

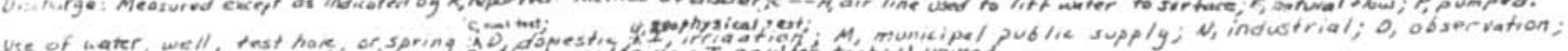

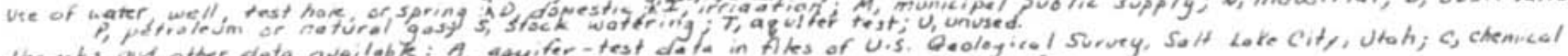

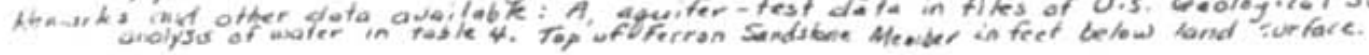

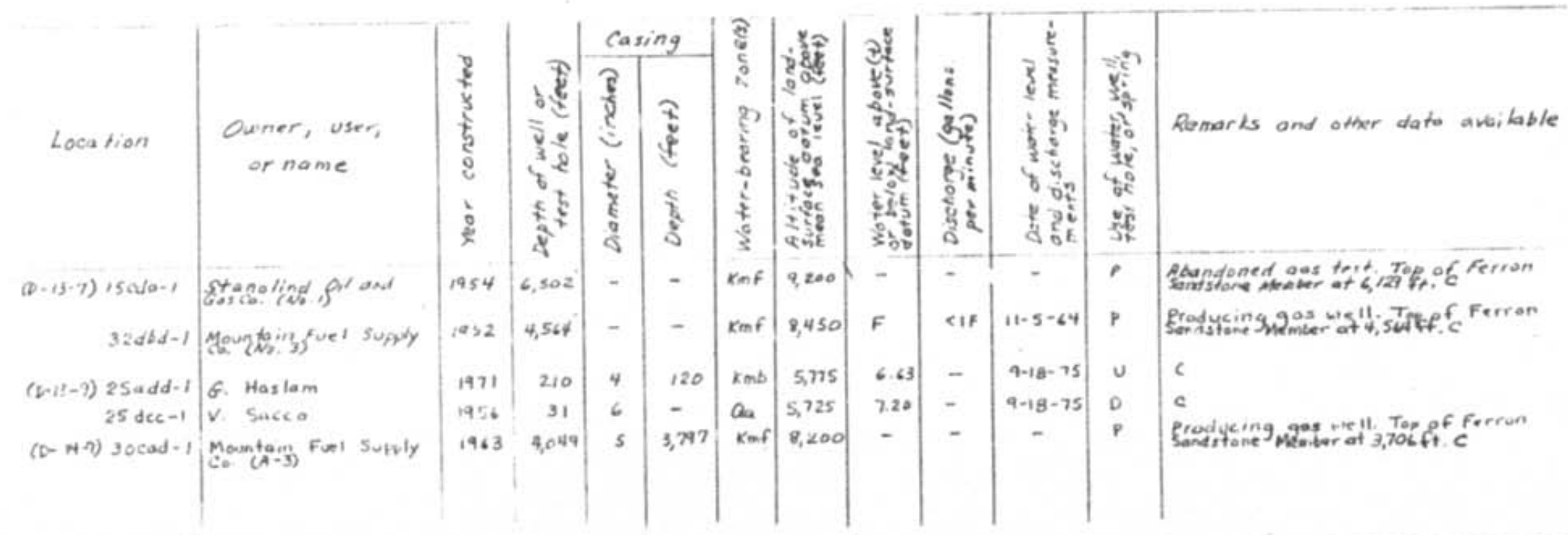




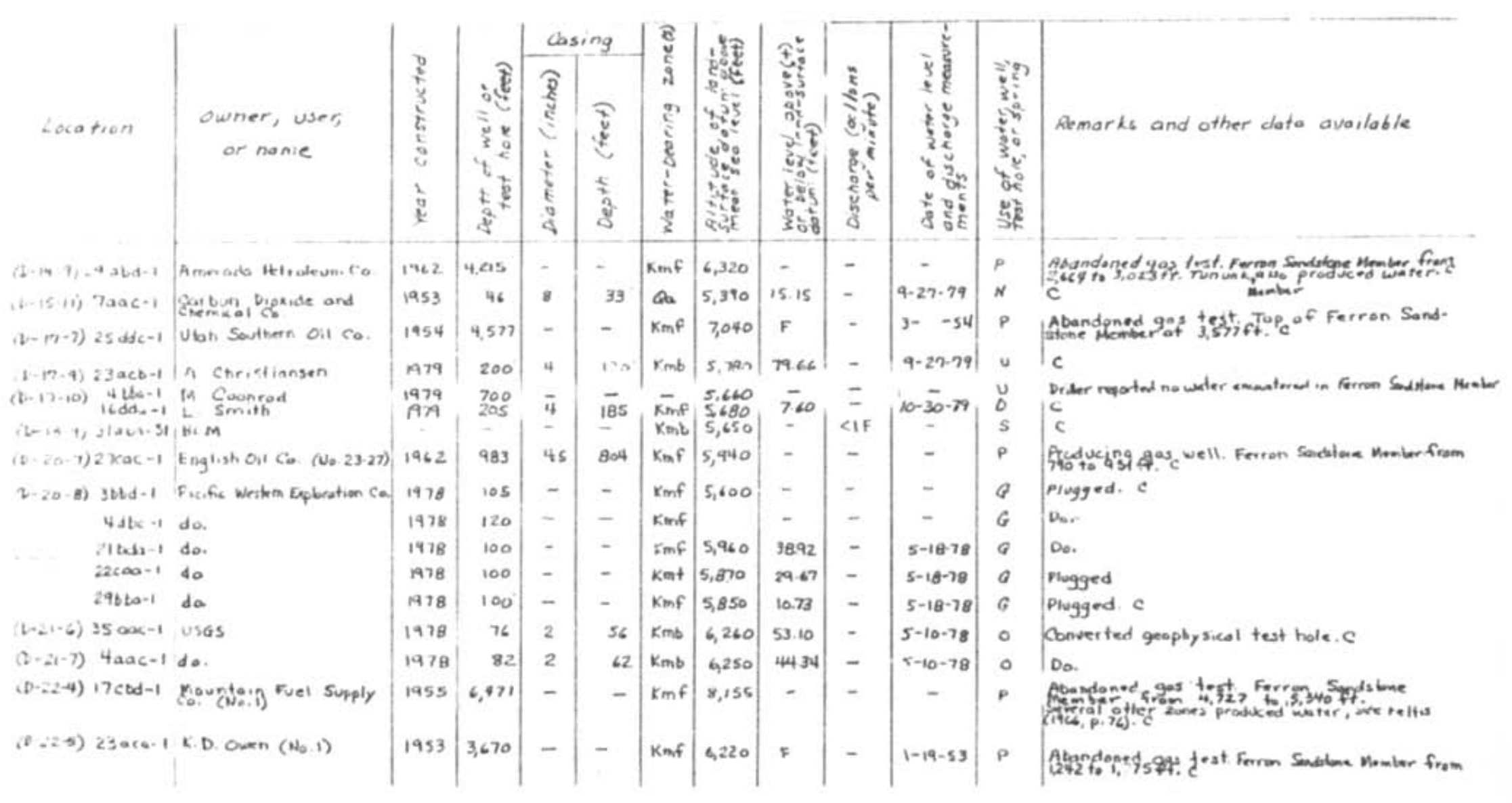




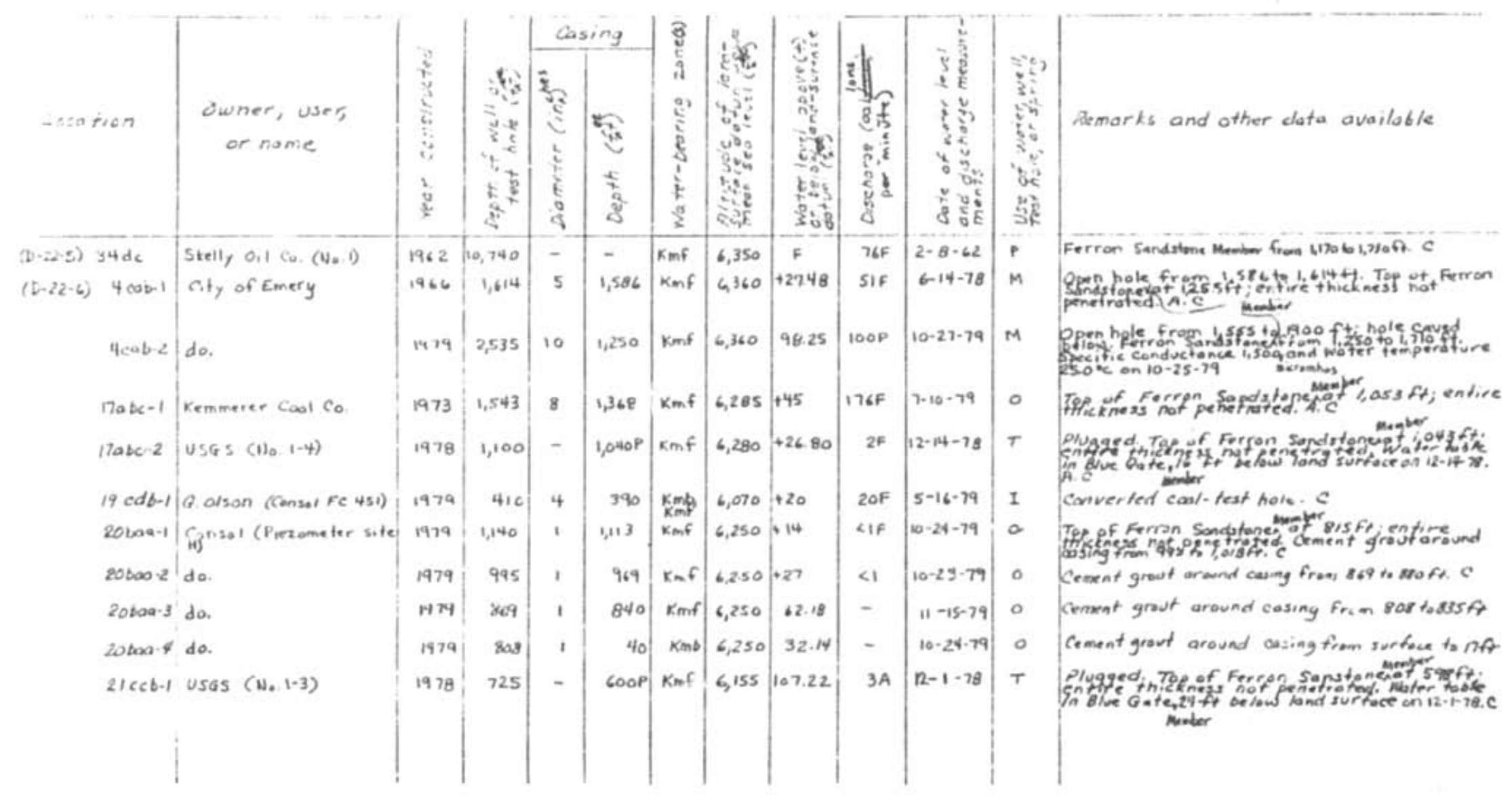




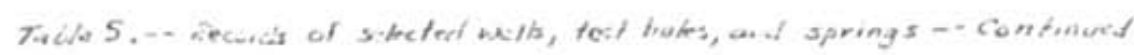

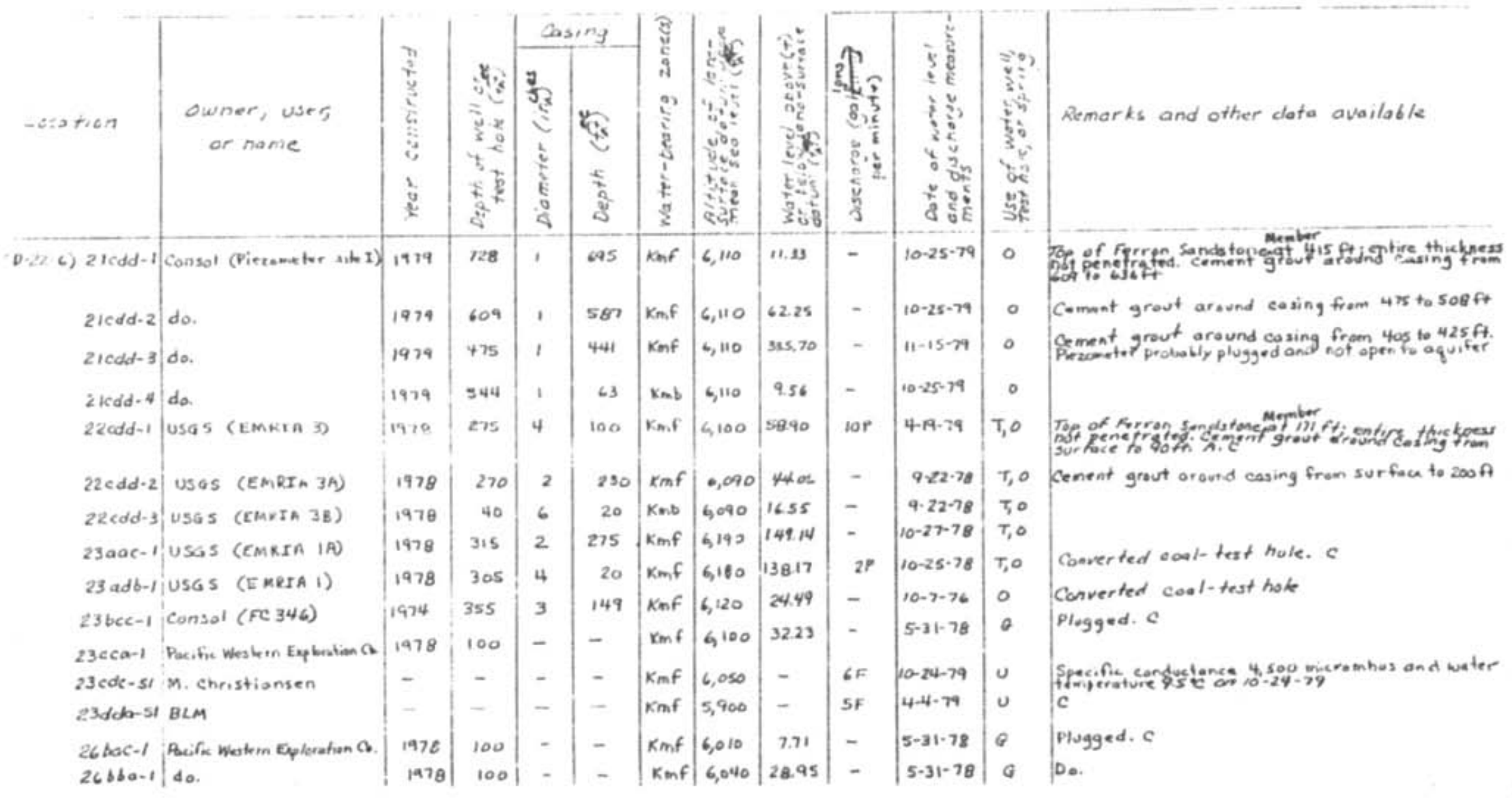




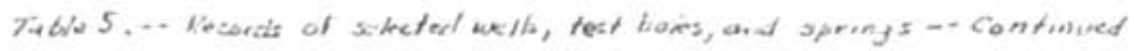

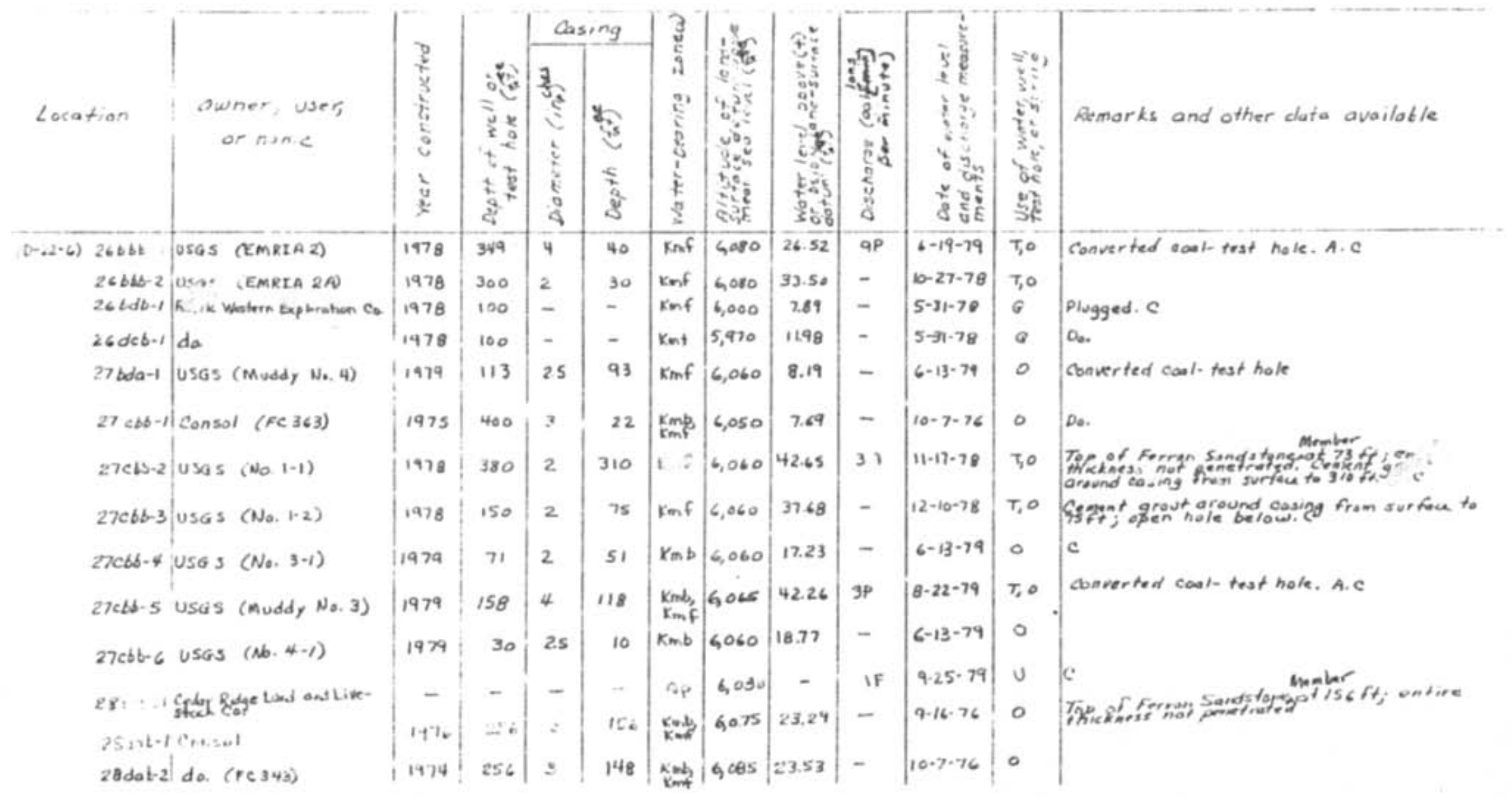




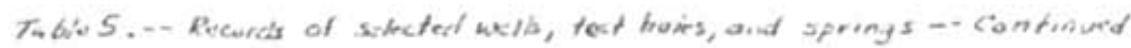

\begin{tabular}{|c|c|c|c|c|c|c|c|c|c|c|c|c|c|}
\hline \multirow{2}{*}{\multicolumn{2}{|c|}{$-e c a t i o n$}} & \multirow[b]{2}{*}{$\begin{array}{l}\text { Owner, wer, } \\
\text { or nanie }\end{array}$} & \multirow{2}{*}{$\begin{array}{l}\frac{5}{2} \\
\frac{2}{2} \\
\frac{2}{5} \\
5 \\
0 \\
\vdots \\
2 \\
2\end{array}$} & \multirow[b]{2}{*}{ 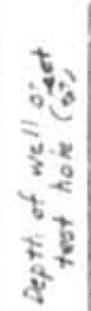 } & \multicolumn{2}{|c|}{ Cusing } & \multirow{2}{*}{ 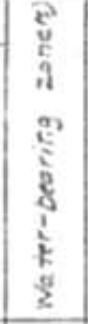 } & \multirow{2}{*}{ 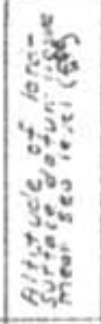 } & \multirow{2}{*}{ 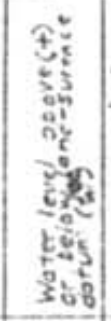 } & \multirow{2}{*}{ 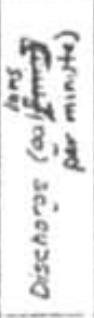 } & \multirow{2}{*}{ 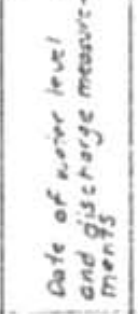 } & \multirow{2}{*}{ 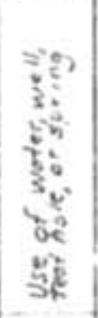 } & \multirow[b]{2}{*}{ femarks and other ciata available } \\
\hline & & & & & $\begin{array}{l}? \\
\vdots \\
\vdots \\
\vdots \\
\vdots\end{array}$ & $\begin{array}{l}\text { בू } \\
\text { है } \\
\text { है }\end{array}$ & & & & & & & \\
\hline-26$)$ & $\sqrt[23 j \cdot b-1]{1}$ & 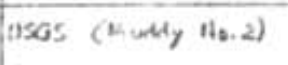 & 1979 & 136 & 2.5 & 96 & Kmif & 6,045 & 44.18 & $\overline{-}$ & $6-13-79$ & $\circ$ & Convertend coal-test hale \\
\hline & zathat & A. $2 \cdot+$ tisen & - & - & - & - & $a_{r}$ & G140 & - & $6 F$ & $11-15-79$ & $u$ & c \\
\hline & $30 \ldots+1$ & $\left.\sin _{2} \mathrm{l}_{k}\right)(1$ iezometer & 1919 & yxy & 1 & 235 & Kant & 6,030 & +83 & - & $12-4-7$ & 0 & 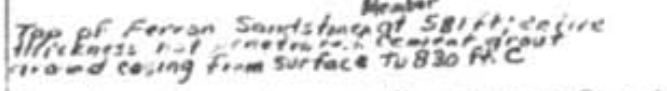 \\
\hline & $300 a t^{2}$ & da. & 1979 & 825 & ' & 398 & Kanf & 6,030 & $F$ & - & $12-4-79$ & 0 & 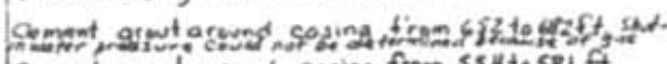 \\
\hline & $3000 \mathrm{~d} \cdot 3$ & de. & 1979 & เ52 & 1 & รงจ & $\operatorname{rmf}$ & 6.030 & +.42 & - & $12=4-79$ & 0 & 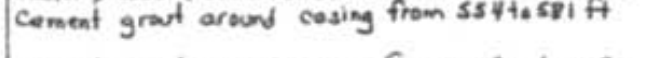 \\
\hline & 30 and-4 & do. & 1979 & 554 & ' & 105 & Kmb & 6,630 & 3.39 & - & $12 \cdot 4 \cdot 79$ & $\circ$ & cement grout arand coung from surface to Iff \\
\hline & Soldd-1 & U:Gs & 1979 & 50 & 2 & 20 & Kat & 4020 & תות & - & $11-7-78$ & 0 & Conwerted geapbysical trut hale \\
\hline & $30 d c b-1$ & I. Lewis & 979 & 608 & 4 & 590 & Kmps & 6,030 & +8.50 & $27 \mathrm{~F}$ & $10-10 x$ & $I, S$ & 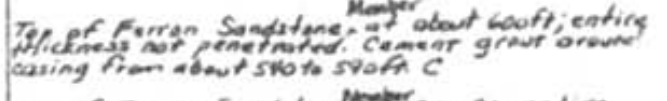 \\
\hline & $3 / d a b \cdot 4$ & E. Brgant & 1972 & 406 & 6 & 360 & Kmf & $6,0,20$ & +10.41 & $45 r$ & $7-6.78$ & $x, s$ & 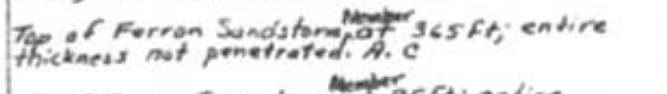 \\
\hline & 32ake-1. & $\begin{array}{l}\text { Consel } \\
\text { sire } A \text { Piezemeter }\end{array}$ & rat & 490 & , & 420 & Km, & 5,980 & 73.02 & - & $11-16-79$ & $\circ$ & 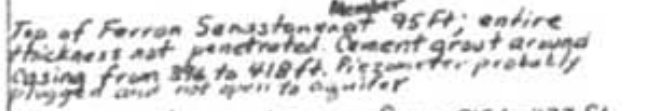 \\
\hline & $32 \operatorname{cdc} 2$ & do. & 1979 & 396 & ' & 336 & Konf & $5,+\infty$ & +1.74 & - & $11-16-79$ & $\circ$ & Cenent growt around casing from 215 to $232 \mathrm{ft}$ \\
\hline & $32 c d c-3$ & & 1979 & 2,2 & 1 & 168 & $\mathrm{kmf}$ & 5,980 & F & - & $11-16-79$ & $\circ$ & 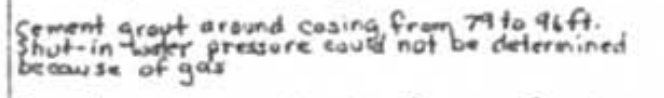 \\
\hline & $320 k-4$ & do. & 1979 & 79 & 1 & 61 & $\mathrm{rmb}$ & 5,980 & 24.84 & - & $\mid 11-16-79$ & $\circ$ & Coment grout around casing from surfou to \\
\hline
\end{tabular}




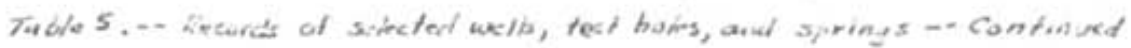

\begin{tabular}{|c|c|c|c|c|c|c|c|c|c|c|c|c|c|}
\hline \multirow{2}{*}{\multicolumn{2}{|c|}{ Lzarion }} & \multirow[b]{2}{*}{$\begin{array}{l}\text { Dwner, user, } \\
\text { or nanie }\end{array}$} & \multirow{2}{*}{ 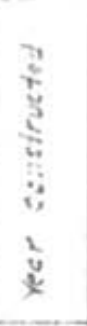 } & \multirow[b]{2}{*}{ 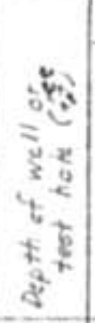 } & \multicolumn{2}{|c|}{ Cosing } & \multirow{2}{*}{ 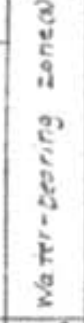 } & \multirow{2}{*}{ 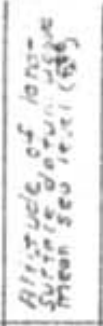 } & \multirow{2}{*}{ 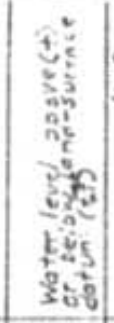 } & \multirow{2}{*}{ 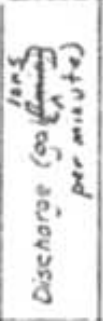 } & \multirow{2}{*}{ 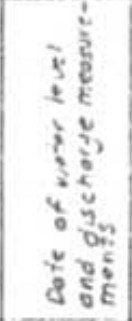 } & \multirow[b]{2}{*}{ 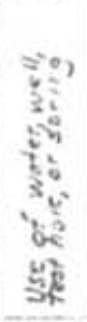 } & \multirow[b]{2}{*}{ Aemark and other clata available } \\
\hline & & & & & 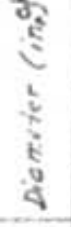 & $\begin{array}{l}\text { है, } \\
\text { के } \\
\text { के }\end{array}$ & & & & & & & \\
\hline \multirow[t]{3}{*}{$(0 \cdot 22-6)=$} & $33 a t b-1$ & usas (Maddy No. 1) & 1979 & 162 & 2.5 & 122 & $\mathrm{Kmf}$ & 640 & 141.08 & - & $7 \cdot 2 \cdot 79$ & 0 & Conderted cul-teat hole \\
\hline & salber & Consol (site 2z) & 1974 & 390 & 4 & 310 & kof & 6,040 & 145.16 & - & $928-79$ & 0 & Septont grout arsurd cesing from surface to \\
\hline & $3+1 t a-1$ & $\operatorname{vescs}\left(\mathrm{N}_{0} \cdot 2-4\right)$ & 1978 & 160 & - & - & $\mathrm{Kmf}$ & 6,110 & 8629 & $3 A$ & $12-12-78$ & $T$ & Plogged. $C$ \\
\hline$(0-22-7)$ & $\begin{array}{l}34 \operatorname{cac}-1 \\
8 \operatorname{loc} t-1\end{array}$ & 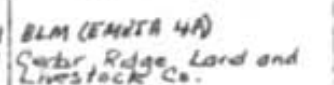 & 1977 & $\begin{array}{l}360 \\
200 \\
130\end{array}$ & $\bar{z}$ & $\begin{array}{l}2>3 P \\
-\end{array}$ & $\sin f$ & 6,200 & $\frac{107.00}{77}$ & $\stackrel{-}{-}$ & $\left|\begin{array}{c}12-14-7 \theta \\
10-26-7 \theta\end{array}\right|$ & $\begin{array}{l}C \\
D\end{array}$ & $\begin{array}{l}\text { C } \\
\text { Plugged. Driller reperted hols was dry } \\
c\end{array}$ \\
\hline \multirow[t]{4}{*}{ (0. 23-5) } & $\begin{array}{l}2 d d z-1 \\
1200 d-1\end{array}$ & 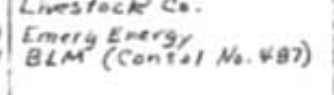 & 1979 & $\begin{array}{l}926 \\
709\end{array}$ & $\overline{6}$ & $\overline{28}$ & $K_{m} \mathrm{mF}$ & $\begin{array}{l}6,340 \\
6,140\end{array}$ & 149E & $\overline{3 F}$ & $\begin{array}{c}4-18-7 \\
12 \cdot 2 \theta-79\end{array}$ & $\begin{array}{c}c \\
s\end{array}$ & 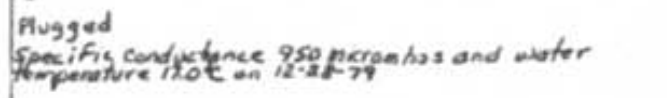 \\
\hline & Basa-1 & (Consol & 1979 & 540 & - & - & $\operatorname{kin} f$ & 6,020 & 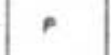 & - & $8-1-7 b$ & c & Plogged. C \\
\hline & & R. Tensen & - & - & - & - & $k m x$ & 6,280 & - & SF & $7-24-79$ & $u$ & is \\
\hline & Ilaba-1 & Tohnson Land and Lin- & 1977 & 9,340 & 6 & 339 & $\operatorname{Kmf}$ & 6,720 & +3 & If & $8 \cdot 31-79$ & $s$ & 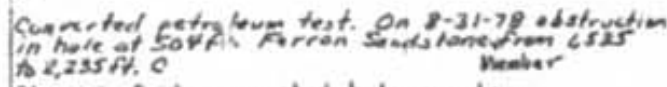 \\
\hline \multirow[t]{4}{*}{$(0-23-6)$} & $\begin{array}{l}\text { Ude-1 } \\
4 \Delta<b-1\end{array}$ & $\begin{array}{l}\text { OLM } \\
\text { USGS }(E M R T H S)\end{array}$ & $\begin{array}{l}1977 \\
1978\end{array}$ & $25+1$ & $\overline{-}$ & $\bar{z}$ & $\operatorname{Kimf}$ & $\begin{array}{l}6,580 \\
6,180\end{array}$ & $2 \overline{289} 49$ & $\overline{\text { «A }}$ & $11-\overline{30}-78$ & $\stackrel{c}{\mathrm{~T}}$ & $\begin{array}{l}\text { phosed. Orither reverted hole eses dry } \\
\text { plogged. C }\end{array}$ \\
\hline & bace-1 & UsGs (No.2-1) & 1978 & $\begin{array}{l}385 \\
720\end{array}$ & $\overline{-}$ & 665 & $\operatorname{Km} m$ & 6,040 & $\begin{array}{r}1 E< \\
+122\end{array}$ & $23 \mathrm{~A}$ & $\begin{array}{l}11-21-78 \\
11-28-78\end{array}$ & $T$ & 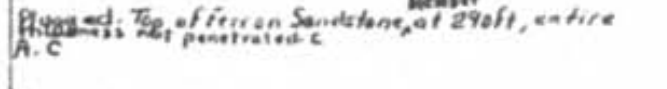 \\
\hline & $17 d b a-5 \mid$ & $B L M$ & - & - & - & - & Kmf & 5,830 & - & If & $11-8-78$ & $v$ & ent arout around cosing frem serfoce to $165 \mathrm{f}$ \\
\hline & 18 bac 1 & 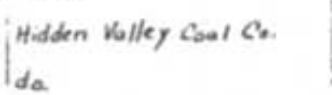 & $\begin{array}{l}1977 \\
1977\end{array}$ & $\begin{array}{c}439 \\
55 !\end{array}$ & $\begin{array}{l}2.75 \\
2.75\end{array}$ & $\begin{array}{l}165 \\
155\end{array}$ & Konf & $\begin{array}{l}6,020 \\
6,060\end{array}$ & $\begin{array}{l}F R \\
F R\end{array}$ & $\begin{array}{l}\text { ITFR } \\
6 F R\end{array}$ & $\begin{array}{l}\theta-4-7 \theta \\
3-1-77\end{array}$ & $u$ & 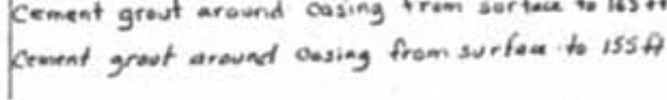 \\
\hline
\end{tabular}




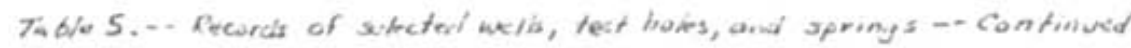

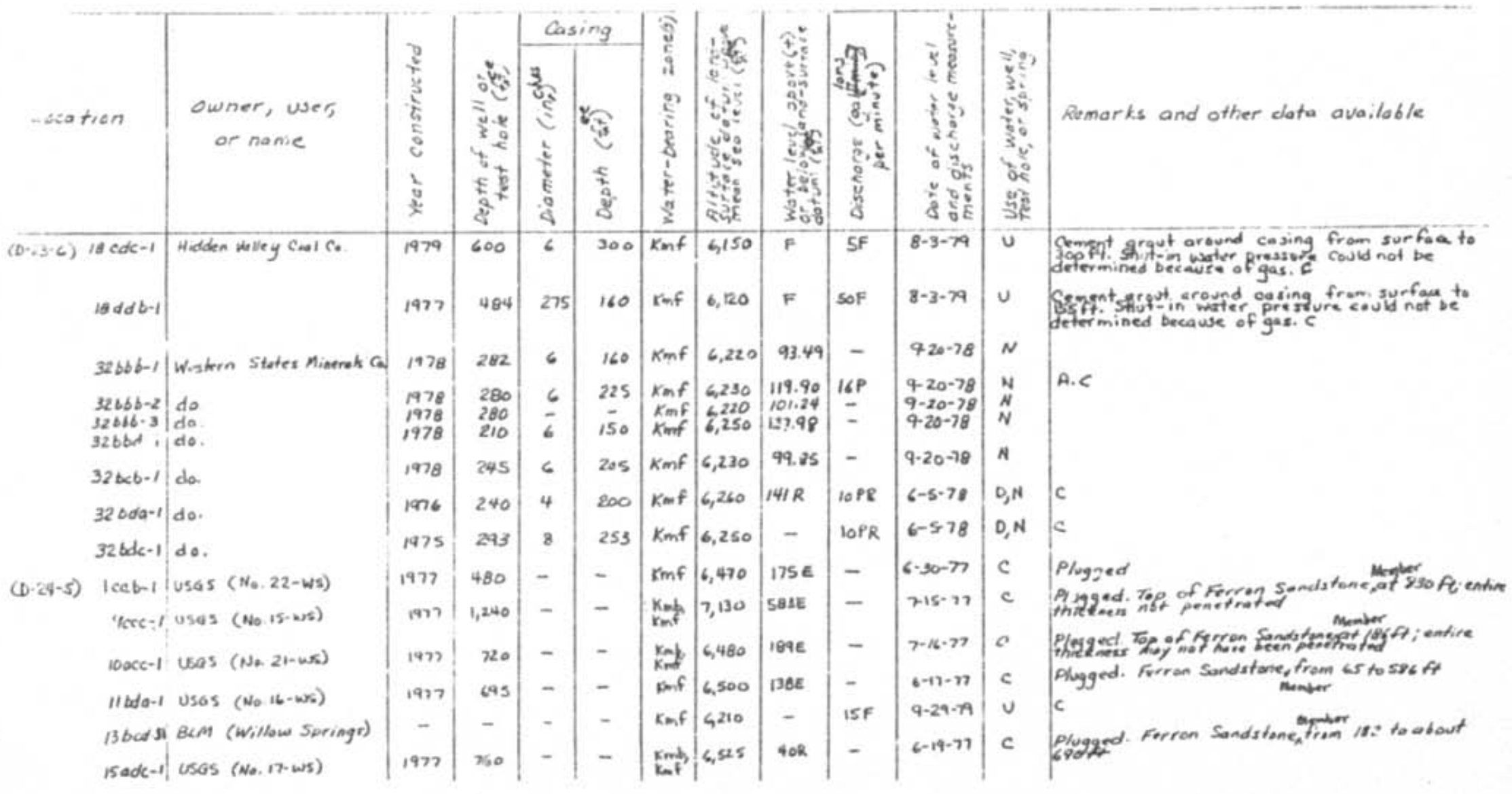




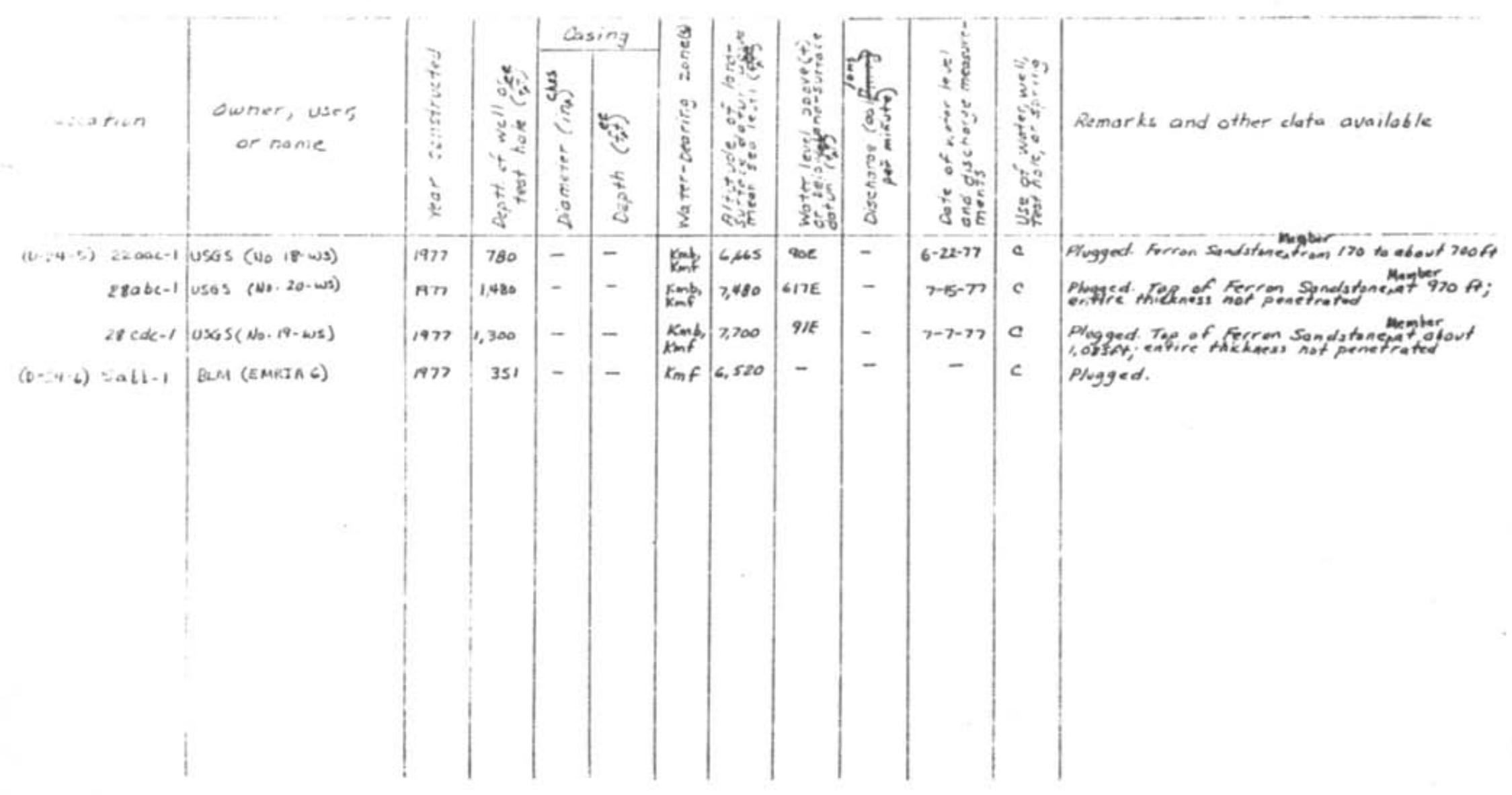


Table 6..- Chemical analyses of water from wels, teithoks, springs,and ine Emery Bline.

Losation: sea description of well- and spring numbering spotem. Suffix $M$ indicater sample collecked in Emery Mine.

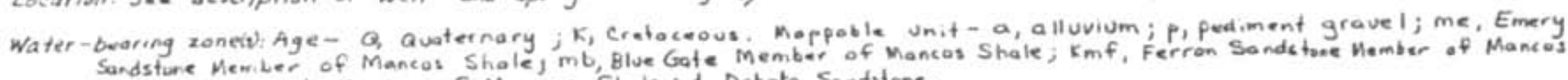
Stele; mt, Tununk Member of Mancor Stale; d, Dakate Sandutone.

Methad of collection: A, air line used to I.ft water to surfoce; B, bo.led;
DS, sample recovered from drist-stem test; $F$, natural flow; pumped.

pH: Field determination except $L$, determined in laboratory.

Dissolved solids: Calculated from sum of corstituents.

Specific conductance: Field determination except $L$, determined in laboratorg

Source of onalytical data: CGL, Chemical and dealogieal Loboratories, Cosper, Wyoming; CL, Core Laboratories, Dalles, Teras; GS, U.S. Oeologicel Surrey. 


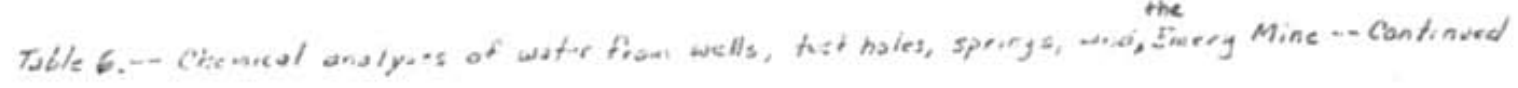

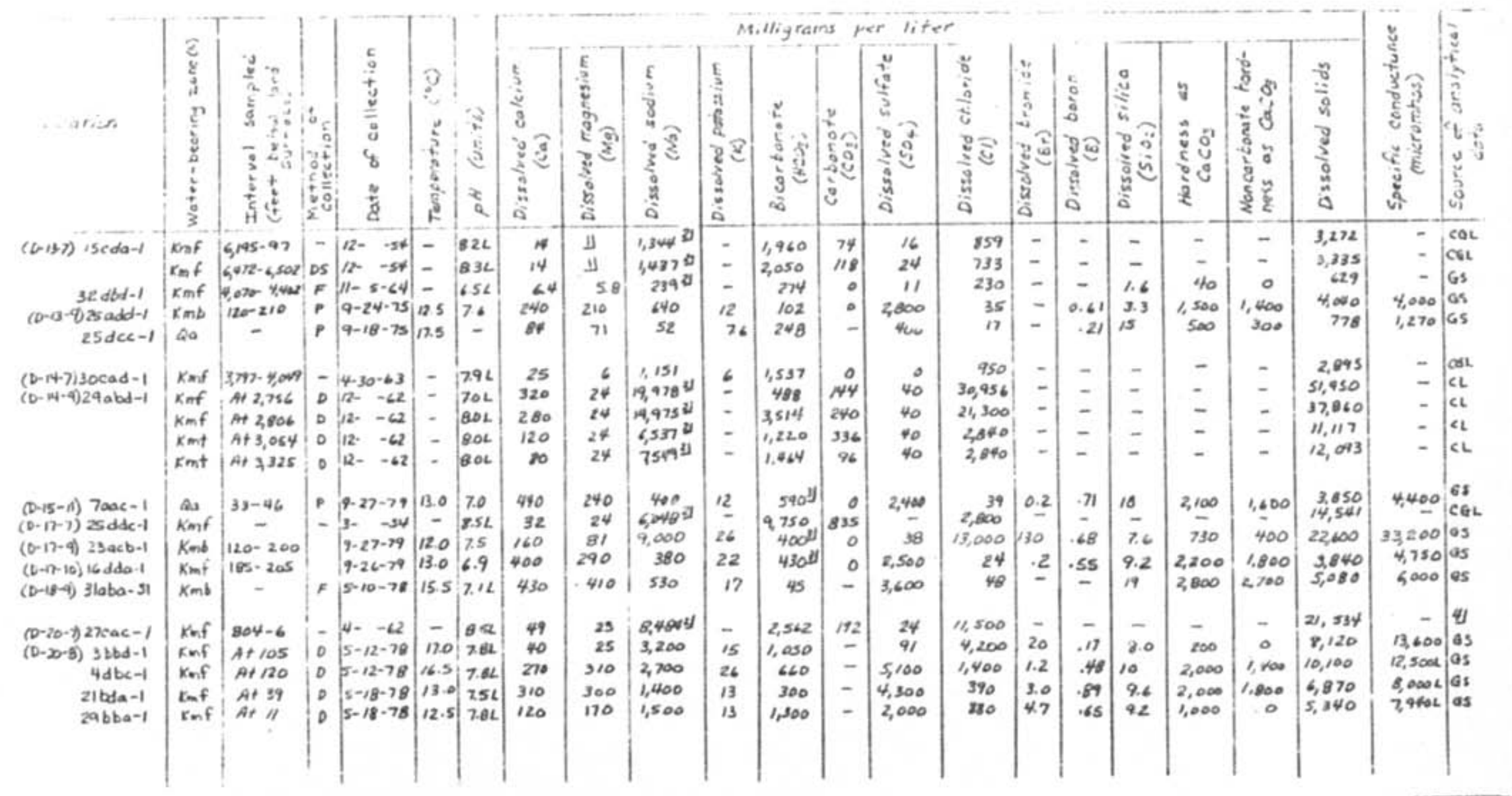




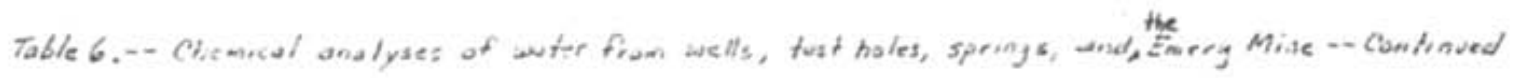

\begin{tabular}{|c|c|c|c|c|c|c|c|c|c|c|c|c|c|c|c|c|c|c|c|c|c|c|}
\hline$\therefore$ ation & 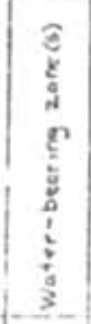 & 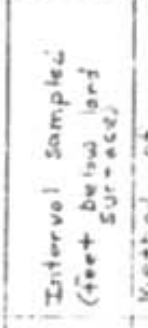 & 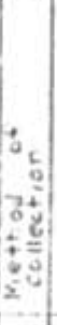 & $\begin{array}{l}5 \\
0 \\
5 \\
0 \\
0 \\
0 \\
8 \\
8 \\
8 \\
8\end{array}$ & 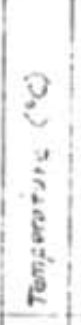 & $\mid \begin{array}{c}2 \\
0 \\
\vdots \\
5 \\
2 \\
2 \\
2\end{array}$ & 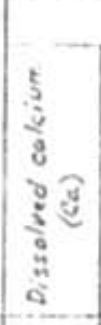 & 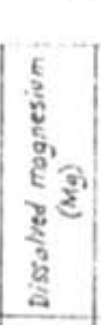 & $\begin{array}{l}\frac{\varepsilon}{3} \\
3 \\
3 \\
3 \\
3 \\
0 \\
0 \\
0 \\
0 \\
0\end{array}$ & 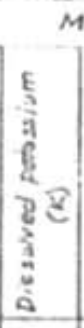 & 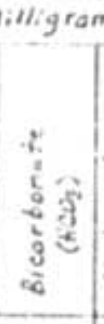 & 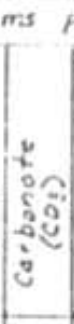 & 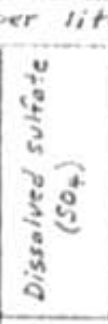 & 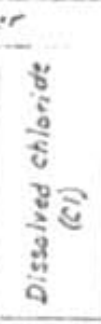 & 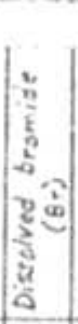 & \begin{tabular}{|c|}
5 \\
0 \\
3 \\
3 \\
92 \\
3 \\
3 \\
3 \\
0
\end{tabular} & 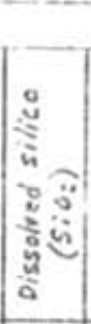 & 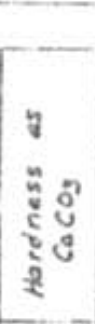 & 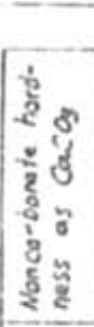 & 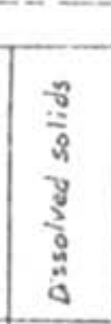 & 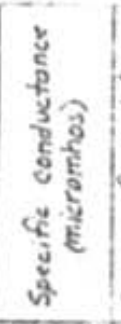 & 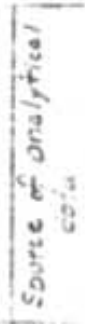 \\
\hline$(b-1-6)=5$ sones -1 & Kab & $56-76$ & $B$ & $|2-10-78|$ & $\mid 135$ & 7.1 & 90 & 190 & $2,6 \infty$ & 29 & 750 & - & 7,000 & & 17 & 15 & 12 & & $3 \%$ & 19,400 & 31,000 & 103 \\
\hline 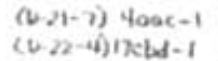 & Kanb & $\mid \begin{array}{l}62-82 \\
2005-2,007\end{array}$ & 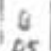 & $\left|\begin{array}{l}30-20 \\
-10-20-51\end{array}\right|$ & 130 & $\therefore 6$ & 29 & 15 & 2,200 & 12 & 540 & $\circ$ & 3000 & $9 / 0$ & i3 & $.7 p$ & 8.7 & 30 & 0 & 6,450 & 9000 & 65 \\
\hline & Kmf & ४) $12=5$ & os & $\mid \begin{array}{l}\mid 2-5-53 \\
1-21-56\end{array}$ & - & $\left|\begin{array}{l}7.74 \\
202\end{array}\right|$ & $\begin{array}{l}49 \\
471\end{array}$ & $\begin{array}{l}13 \\
126\end{array}$ & $\begin{array}{r}603^{3} y \\
6,202 y\end{array}$ & $\bar{z}$ & $\begin{array}{l}980 \\
\text { 1,ass }\end{array}$ & - & $\begin{array}{l}597 \\
10,116\end{array}$ & 2.46 & - & - & 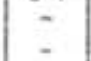 & $\overline{-}$ & $\overline{-}$ & 1.793 & & arc \\
\hline & Komf & $082-98$ & os & $\mid-28-56$ & - & 602 & Sos & 190 & 7981 b & - & 20 & - & $13,4 / 5$ & 3,600 & 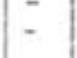 & - & - & 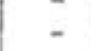 & $\overline{-}$ & $\begin{array}{l}20,145 \\
25,931\end{array}$ & -1 & $\mathrm{kol}$ \\
\hline & knf & $4,910-20$ & DS & $\mid-2>-56$ & - & 252 & 153 & 41 & $1,793^{2}$ & - & 1,560 & - & 2,263 & 580 & - & - & $=$ & $\theta_{0}$ & & & & \\
\hline & $k_{m f}$ & $5226-92$ & es & $2-10-56$ & - & c.st & sity & 154 & 36604 & - & 610 & - & 8473 & too & - & $\overline{-}$ & $\overline{-}$ & $\overline{-}$ & $\overline{-}$ & 5,598 & - & has \\
\hline & ed & $6 A_{1}<4212$ & ins & $|2-26-56|$ & - & csl & $4 \times 98$ & 1042 & 2,0100 & - & 645 & - & 41 & 4000 & 1- & - & - & . & - & 13, sol & - & 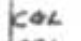 \\
\hline$(0-22-6)<\operatorname{sen} \theta-1$ & $K_{m f}$ & jises:is | & If & $|/ 2-A-53|$ & - & - & 109 & $\$ 2$ & $2 \ln 2$ & - & 395 & - & 4,63 & 575 & - & 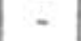 & - & - & $\overline{-}$ & 68909 & $\overline{-}$ & $\mathrm{kac}$ \\
\hline & Kmf & p,-345-1,4ced & DS & $|1-22.53|$ & - & - & 221 & 48 & $2,397^{ \pm 1}$ & - & 452 & - & 4824 & 703 & - & - & - & - & - & $\begin{array}{l}2370 \\
3,015\end{array}$ & $\overline{-}$ & as \\
\hline & $K m f$ & $6423-96$ & . 15 & $1-2 y-53$ & - & - & 209 & 40 & 24925 & - & 437 & - & 4,575 & 702 & - & - & - & - & - & 8,2 & - & los \\
\hline 344 & $\begin{array}{l}K m f \\
K_{m} f\end{array}$ & $\left|\begin{array}{l}1,570-10 \\
1,77+-20 x\end{array}\right|$ & Ds & $\mid \begin{array}{l}18-53 \\
2-8-62\end{array}$ & - & 1,26 & 212 & 62 & 2072 & - & 855 & - & 3,465 & 707 & - & - & - & - & - & 6,954 & - & as \\
\hline$=2-\sqrt{2}+a-b-1$ & Kan & $|1506-3604|$ & $r$ & $2-5-79$ & 26.0 & $\mid \begin{array}{l}126 \\
7.9\end{array}$ & $\begin{array}{l}48 \mathrm{~g} \\
31\end{array}$ & $\begin{array}{l}24 \\
19\end{array}$ & $\begin{array}{l}2,600^{\circ} \\
180\end{array}$ & $\overline{4}, 1$ & $\begin{array}{l}370 \\
300\end{array}$ & 0 & 5,430 & 567 & 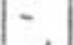 & 19 & 15 & 1,320 & 1,00 & 9,510 & $09>001$ & os \\
\hline $1700<-1$ & $K_{m f}$ & $\left|, 268-k_{6},-3\right|$ & $F$ & $7-10-79$ & 25.0 & 7.62 & 29 & 19 & 200 & 4.4 & $\begin{array}{l}200 \\
300\end{array}$ & 0 & $\begin{array}{l}350 \\
300\end{array}$ & $\begin{array}{l}20 \\
32\end{array}$ & $\left|\begin{array}{l}.1 \\
.2\end{array}\right|$ & $\mid .22$ & $\begin{array}{l}15 \\
16\end{array}$ & 1,150 & 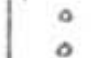 & $\begin{array}{l}757 \\
749\end{array}$ & , 100 & as \\
\hline$c-2$ & $K \operatorname{mof}$ & $1,0 \times 0-1,100$ & $F$ & $|2-N V-78|$ & piss & 2.1 & 19 & 14 & 20 & s.1 & 310 & 0 & aves & & & & & & & & & \\
\hline & $k a b, \ln f$ & $390-4 / 0$; & $f$ & $|5-16-79|:$ & 205 & $x+1$ & 36 & 19 & 220 & 4.4 & & - & 340 & 30 & .2 & .29 & 16 & 110 & $\circ$ & 967 & 1,490 & as \\
\hline & $\mathrm{kmf}$ & $|1,0,8-1, \pi 0|$ & $r$ & $|10-24 \cdot 7|$ & 12.5 & 22 & 25 & 40 & 300 & s.o & 470 ' & 0 & 250 & 23 & .3 & .25 & 12 & 170 & - & 608 & 1,250 & Gs \\
\hline & $K_{m f}$ & 180.745 & $F$ & $\mid r 23-79$ & $|11.5|$ & 88 & 36 & 79 & 260 & s.1 & $510^{3}$ & - & 420 & 23 & .1 & 31 & 25 & 3 & 0 & 83. & 1,350 & ps \\
\hline $2 t<c b-1$ & $k=$ & $600-725$ ! & $A$ & $|11-30-70|$ & |10s! & 9.0 & 17 & 16 & 460 & 4.4 & 500 & $s$ & soo & 31 & 2 & \begin{tabular}{|c|}
.20 \\
.61
\end{tabular} & 22 & 120 & $\therefore$ & 93 & Noo & las \\
\hline & 1 & & & & & & & & & & & & & & & & 12 & 170 & $a$ & 3,420 & 2,100 & \\
\hline
\end{tabular}




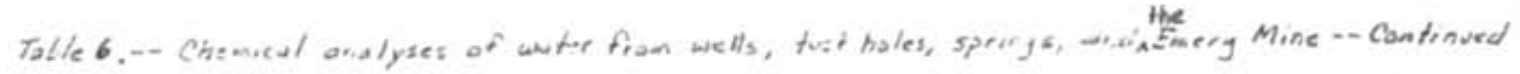

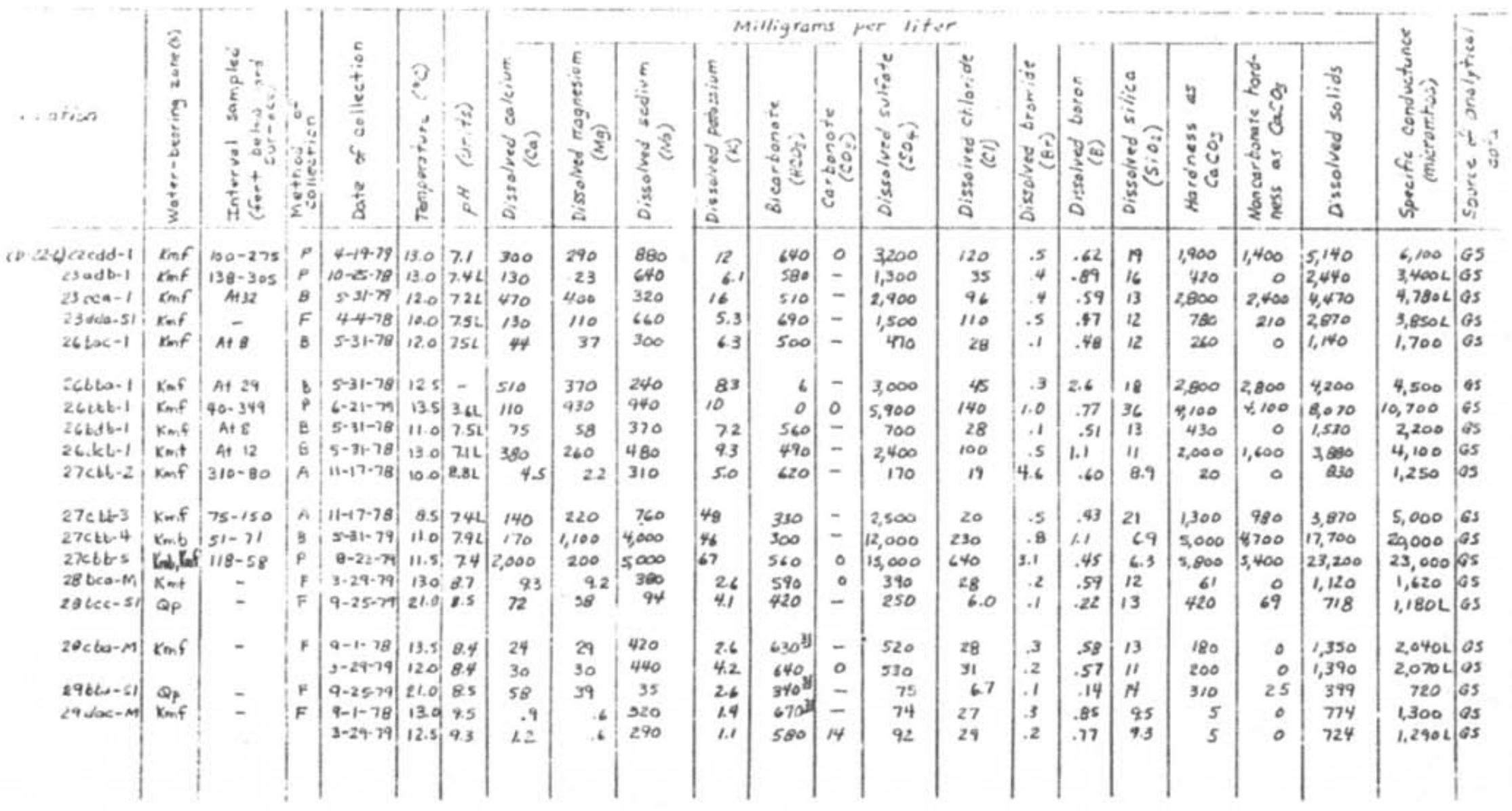




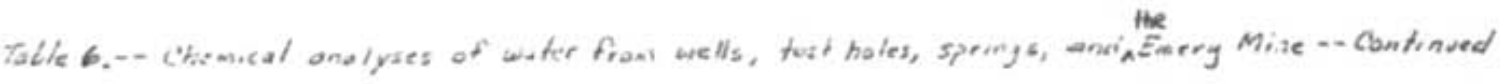

\begin{tabular}{|c|c|c|c|c|c|c|c|c|c|c|c|c|c|c|c|c|c|c|c|c|c|c|}
\hline \multirow[b]{2}{*}{ isiation } & 8 & & & & & & \multicolumn{14}{|c|}{ Milligrams per liter } & \multirow[b]{2}{*}{ 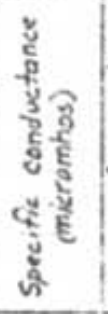 } & \multirow[b]{2}{*}{ 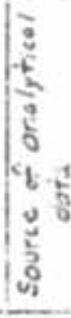 } \\
\hline & 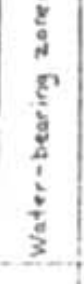 & 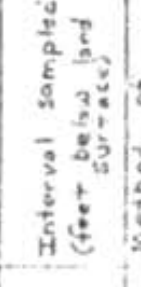 & 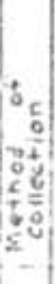 & 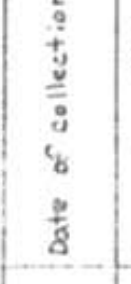 & 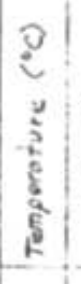 & 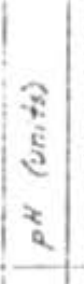 & ב⿱ & 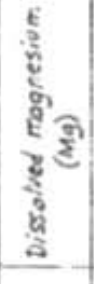 & 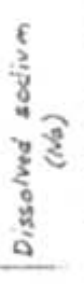 & 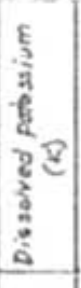 & 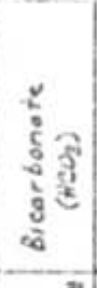 & 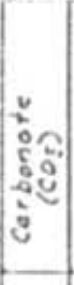 & 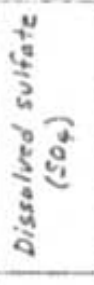 & 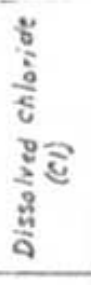 & 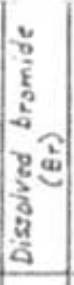 & 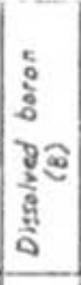 & 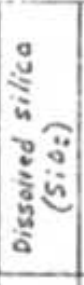 & 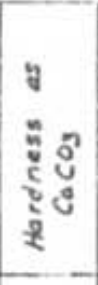 & 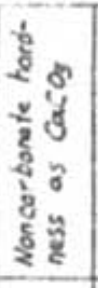 & 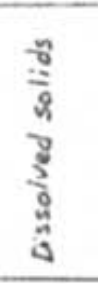 & & \\
\hline$(b / 2<)$ soond-1 & $\mathrm{kmf}$ & $820-8 Y$ & $F$ & $|10-15-79|$ & 19.0 & 8.0 & 12 & 6.9 & 220 & 44 & $40^{3}$ & 0 & 180 & 16 & .1 & .35 & 14 & 58 & 0 & 652 & 1,100 & GS \\
\hline sodeb-1 . & Kanf & $570-6008$ & $F$ & $|9-28-79|$ & 16.0 & 8.8 & 410 & 300 & 370 & 1.5 & $310^{8}$ & - & 2700 & 24 & 2 & $.5 s$ & 83 & 2,300 & 2,000 & 3,970 & $4,54 \alpha$ & as \\
\hline sidab-1, & Konf & $360-\sqrt{06}$ & $F$ & $|10-7-76|$ & 120 & 79 & 39 & 18 & 360 & 3.7 & 299 & - & 600 & 45 & - & .28 & 14 & 160 & 0 & 1,230 & $1,800<$ & as \\
\hline $32 a b a \cdot m$ & $\mathrm{kmp}$ & - & $F$ & $3-24 \cdot 9$ & 10.0) & 89 & 8.6 & 10 & 640 & 46 & 520 & 37 & 830 & 7 & .3 & $8 s$ & 22 & 63 & $\therefore$ & 1,400 & 3,000 & Qs \\
\hline $53 a b t-2$ & $\mathrm{kmin}$ & $310-90$ & A & $9-12-79$ & 16.9 & 0.9 & 10 & 45 & 240 & 65 & 494 & 65 & 130 & 13 & .1 &.$\infty$ & 21 & 36 & 0 & 904 & 250 & as \\
\hline 34tta-1 & $k m f$ & At 160 & D & $\mid 2-12-78$ & 10.5 & 8.9 & 10 & 6.3 & 260 & 6.3 & 430 & - & 230 & 23 & .1 & .36 & $\|$ & 5) & 0 & 759 & 1,100 & as \\
\hline & $\operatorname{smf}$ & $|273-360|$ & $A \mid$ & $|12-14-7|$ & 9.0 & 4.1 & 14 & 7,4 & 300 & 5.2 & 700 & 17 & 140 & $2 t$ & .2 & .47 & 39 & 65 & - & 694 & 1,320 & as \\
\hline$(0-22-1) 8 b \times d-1$ & $k=n f$ & - & $P$ & $4-15-78$ & $15.0 \mid$ & $7 a$ & 420 & 310 & 140 & 5.8 & 600 & - & 2,000 & 46 & 8 & .23 & 25 & 2300 & 1,800 & 3.240 & 37104 & es \\
\hline$(0-23-3) 130-20-1$ & $\mathrm{kon}$ & - & $F$ & $\theta-1.79$ & $-\overline{1}$ & 8.61 & 14 & 8.2 & 220 & 2.8 & 370 & $\vec{a}$ & 230 & is & -1 & 95 & 14 & 69 & $:$ & 687 & 1,0104 & as \\
\hline$|60<0 ;-51|$ & Kme & - & $F$ & $\mid 7-24-79$ & 13.5 & 2.0L & 45 & 27 & 290 & 5.5 & 480 & 0 & 500 & 48 & 1.2 & 36 & 9.8 & 220 & 0 & 1,160 & 1,700 & as \\
\hline alaba-1 & $\mathrm{kmf}$ & - & $F$ & $|8-31 \cdot 78|$ & 13.0 & 8.8 & 1.7 & .2 & 130 & 14 & 260 & 8 & 51 & 15 & .2 & .18 & 15 & 5 & 0 & 351 & 540 & as \\
\hline$(0.23-6) 4 b c b-1$ & Kmf & At 440 & D & $|1-30,28|$ & 14.0 & 8.4 & 110 & 45 & 600 & 84 & 320 & $\circ$ & 1,400 & 83 & .5 & .67 & 8.3 & 460 & 200 & 2,410 & 3,400 & as \\
\hline Gace-1 & $\mathrm{kmf}$ & At 3 as & 0 & $|11-21-76| 1$ & 125 & 8.2 & 35 & 19 & 370 & 41 & 280 & 0 & 660 & 49 & .4 & .30 & 15 & 176 & 0 & 1,290 & 1,980 & as \\
\hline & $\mathrm{kmf}$ & 665.720 & A : & $11-28.7 \theta$ & 13.5 & 8.9 & 13 & 4.3 & 290 & 32 & 370 & 13 & 390 & 30 & .2 & .35 & 11 & so & - & 8n & 1,400 & es \\
\hline indba.51 & $k m f$ & - & $F$ & $|11-8-3 \theta|$ & 130 & 244 & 210 & 190 & 470 & 81 & 360 & - & 1,600 & ISo & 6 & .56 & 16 & 1,300 & 1,000 & 3,020 & 37204 & as \\
\hline $1 \theta c d c-1$ & $\mathrm{Kmf}$ & $300-598$ & $F$ & $\mid \theta-3-79$ & 14.5 & 821 & 27 & 19 & 180 & 4.3 & 290 & - & 290 & 13 & .1 & $n$ & 16 & 150 & - & 693 & จ75 & as \\
\hline $18 d d t-1$ & $\mathrm{kmf}$ & $160-49 f^{\circ}$ & $F$ & $|10-26-78|$ & 170 & 78 & 34 & is & 170 & 4.2 & 280 & 0 & 290 & 16 & .2 & .19 & 15 & 160 & 0 & 686 & 980 & as \\
\hline 32 btt-2 & $k \operatorname{mf}$ & $225 \cdot 80$ & P & $4-22-78$ & 135 & 8.72 & 6.0 & 2.1 & 370 & 18 & 420 & - & 450 & 16 & .4 & 33 & 8.1 & 24 & ० & 1,060 & 1,650 & es \\
\hline 32 Ida-1 & $\mathrm{Kaf}$ & $200-40$ & $\mathbf{p}$ & $6-21-7 \theta$ & 18.5 & 8.04 & 30 & 20 & 930 & 2.7 & $\$ 10$ & - & 440 & 13 & .2 & .25 & "1" & 160 & $\therefore$ & 1,050 & 1,600 & os \\
\hline $32 \mathrm{bdk}-1$ & $\mathrm{~K}_{\mathrm{mf}}$ & $253: 93$ & $P$ & $9 \cdot 24-76$ & $n .0$ & 24 & 5.4 & 4.4 & 290 & 13 & 4,3 & 3 & Yoo & 13 & - & .21 & 83 & 32 & 0 & 834 & $1,250 L$ & as \\
\hline$(0 \cdot 24-5)$ i jocd-si! & Konf & - & $F$ & $|10-15-79|$ & 120 & 2.6 & 100 & 61 & 97 & 7.3 & $970^{3}$ & 0 & 410 & 17 & . & נו & 20 & 500 & 190 & 899 & 1,200 & as \\
\hline
\end{tabular}


Table 6.-- Chem,cal anal, ses of water from wells, test holes, springs, and, Emerg Mine-- Contiaued

\author{
1) Trace. \\ 2) Sodium plus potassium. \\ 3] Estimated from total iaboretorg aikalinity \\ If Analysis supplied t, Pacific Naturel Gos Exploration C.
}




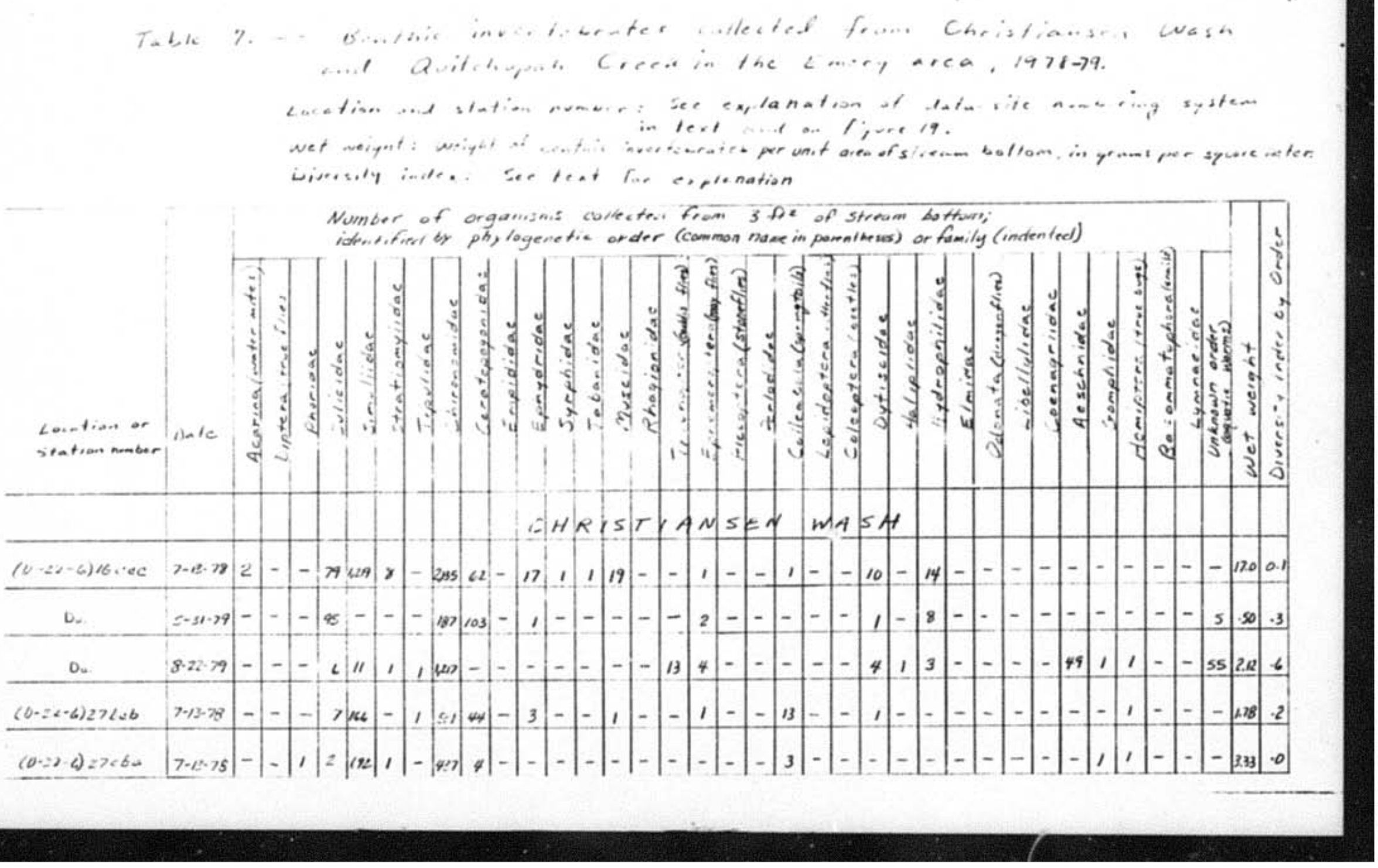


Table g. -- Benthic invertebrates collectel from Christiansen Wash and Quitchupah 3. Creck in the Emers Area, 1978-79-- Continued

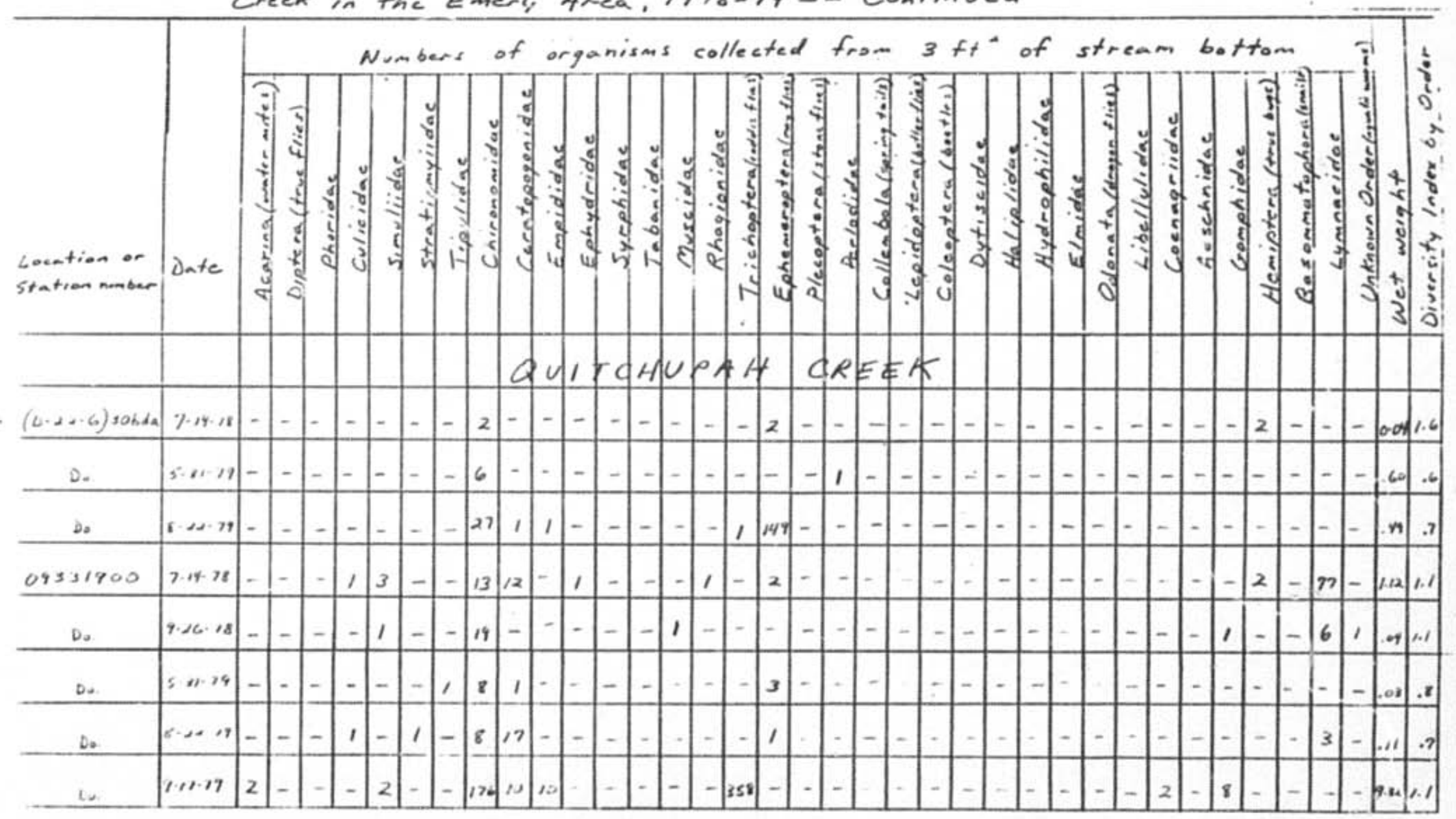


7.ble 7.-- Benthic invertebrates collected from Christiansen Wash and Quitchupah Creek in the Emery 4rea, 1978-79-- Continued

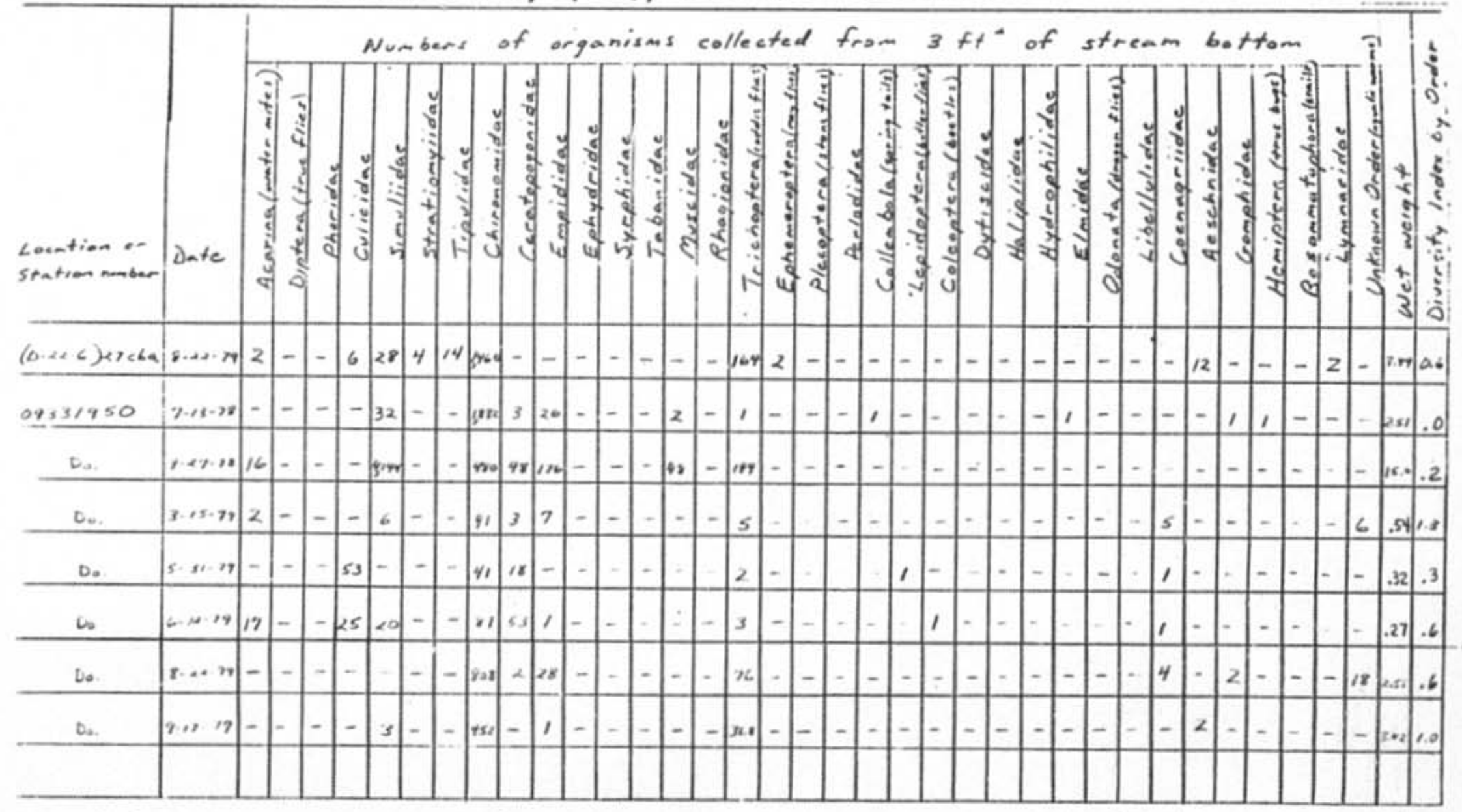


7-ble 7.-- Benthic invertebrates collectel from Christiansen Wash and Quitchupah 4 Creck in the Emery 4rea, 1978-79-- Continued

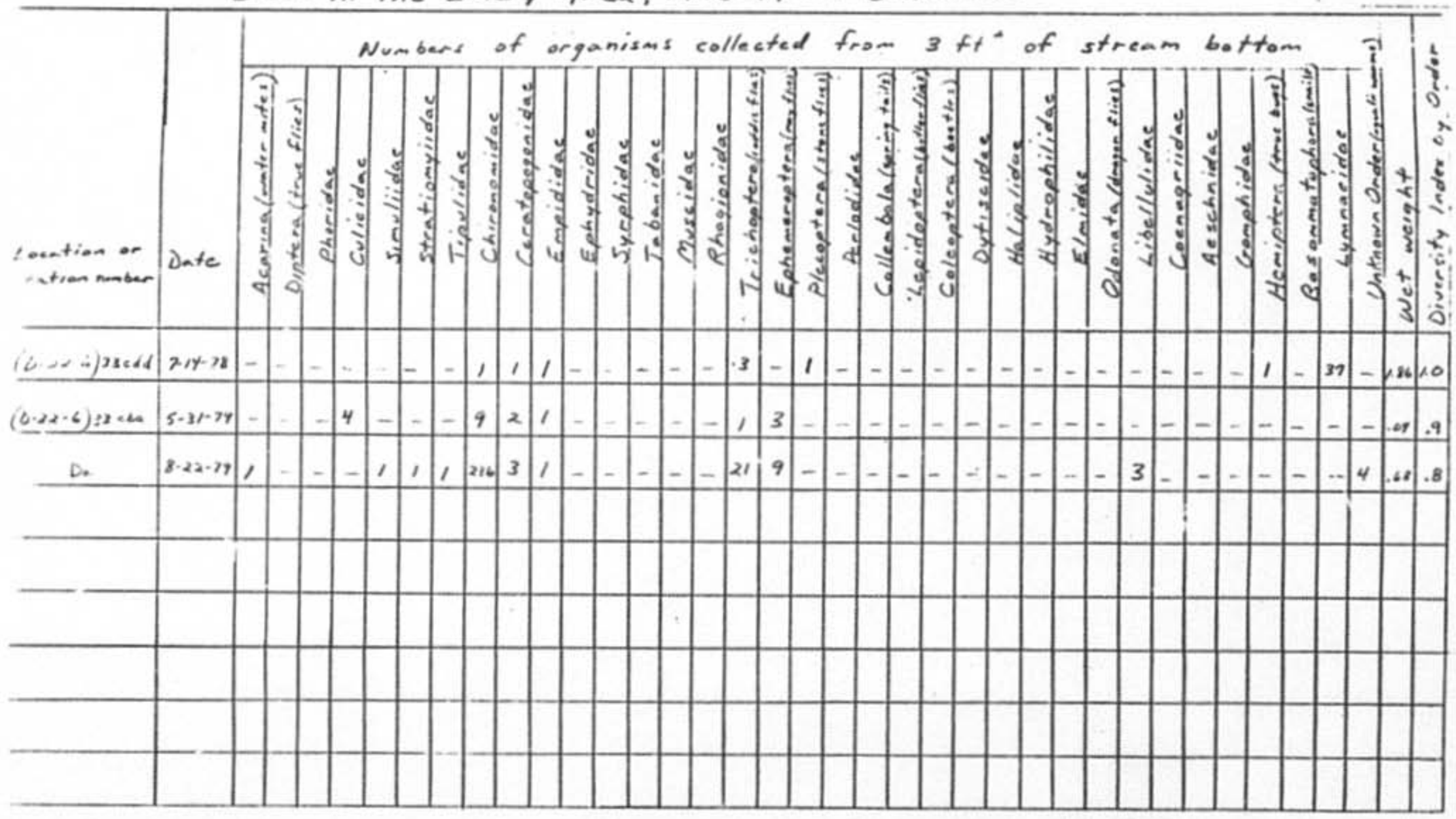




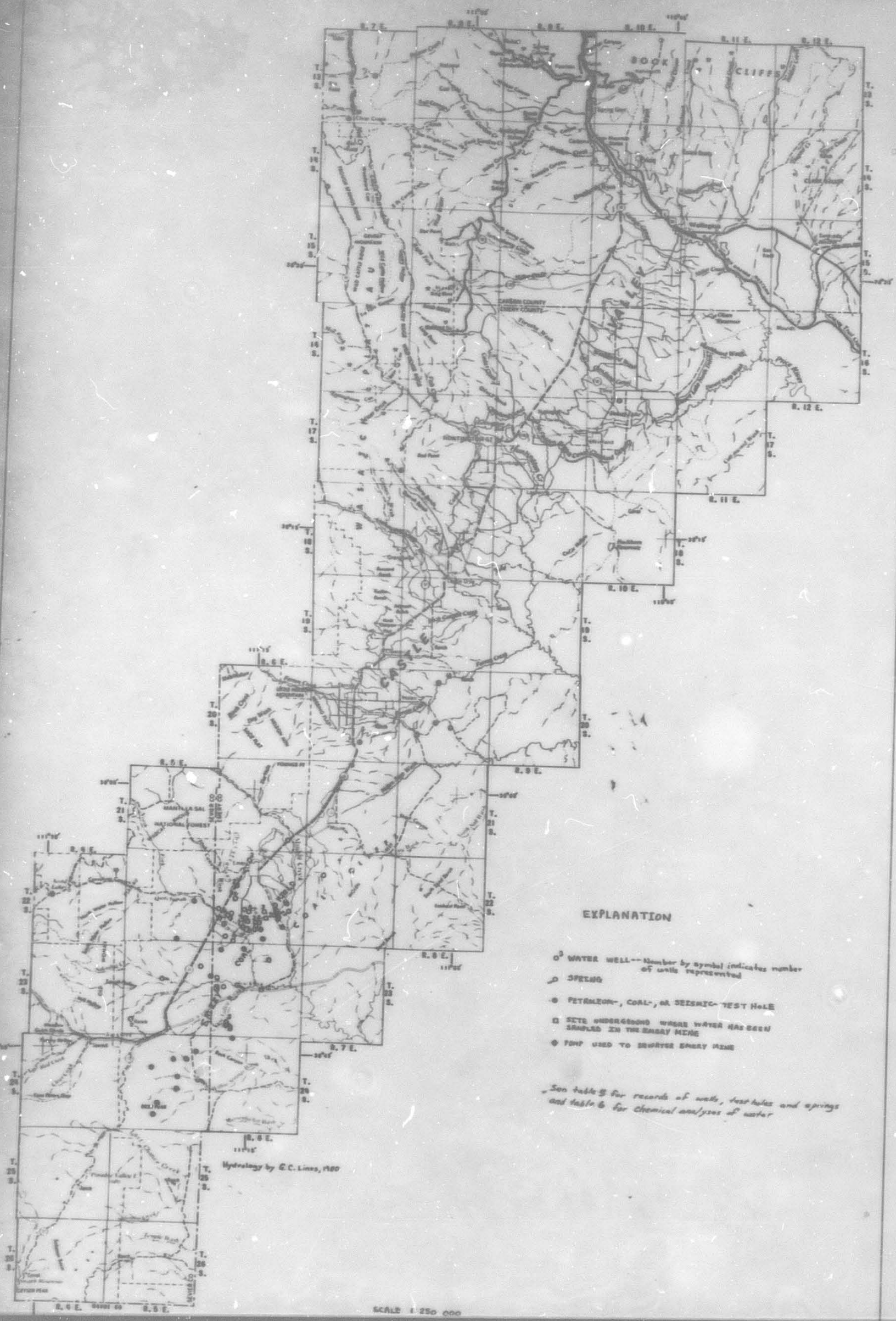


L
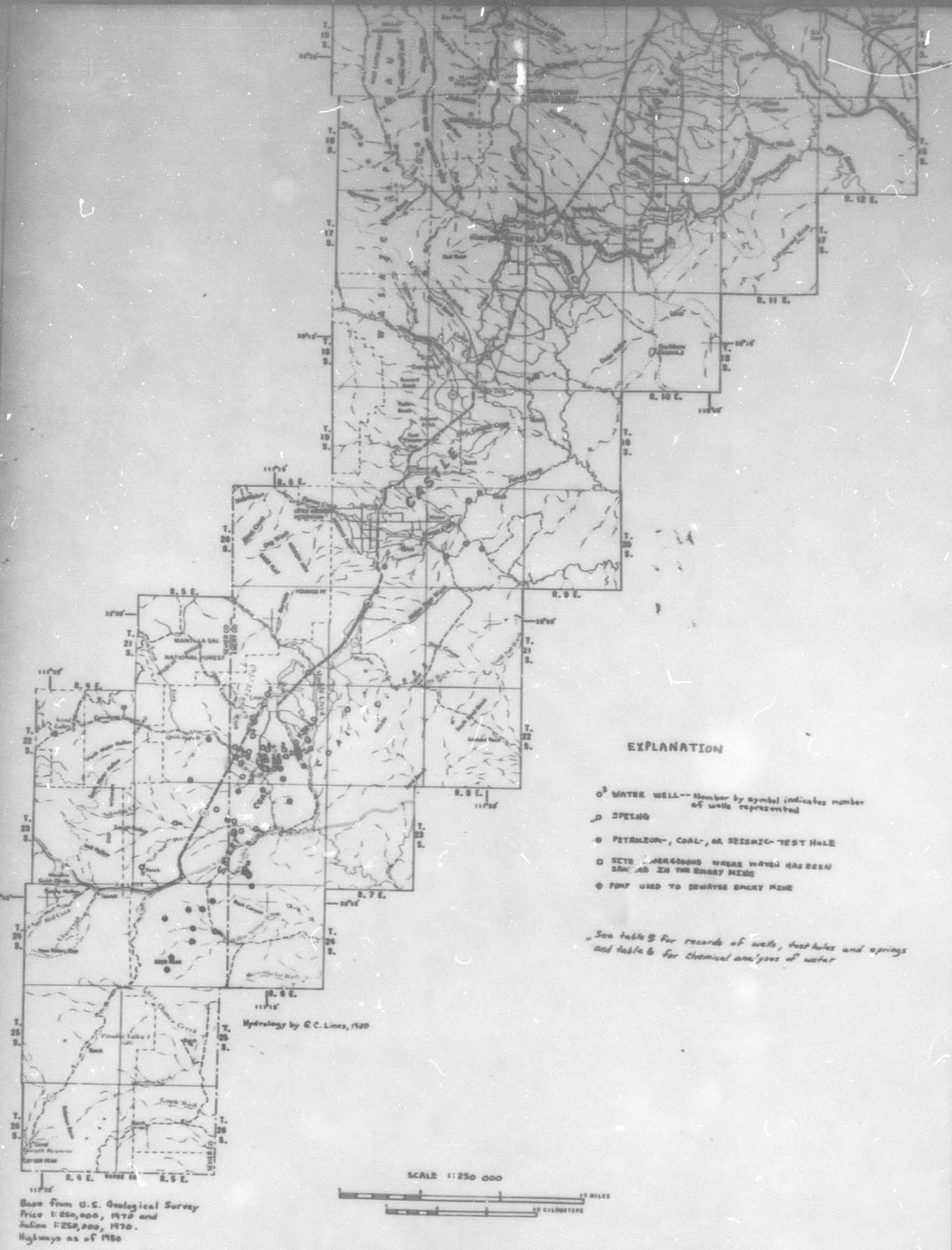


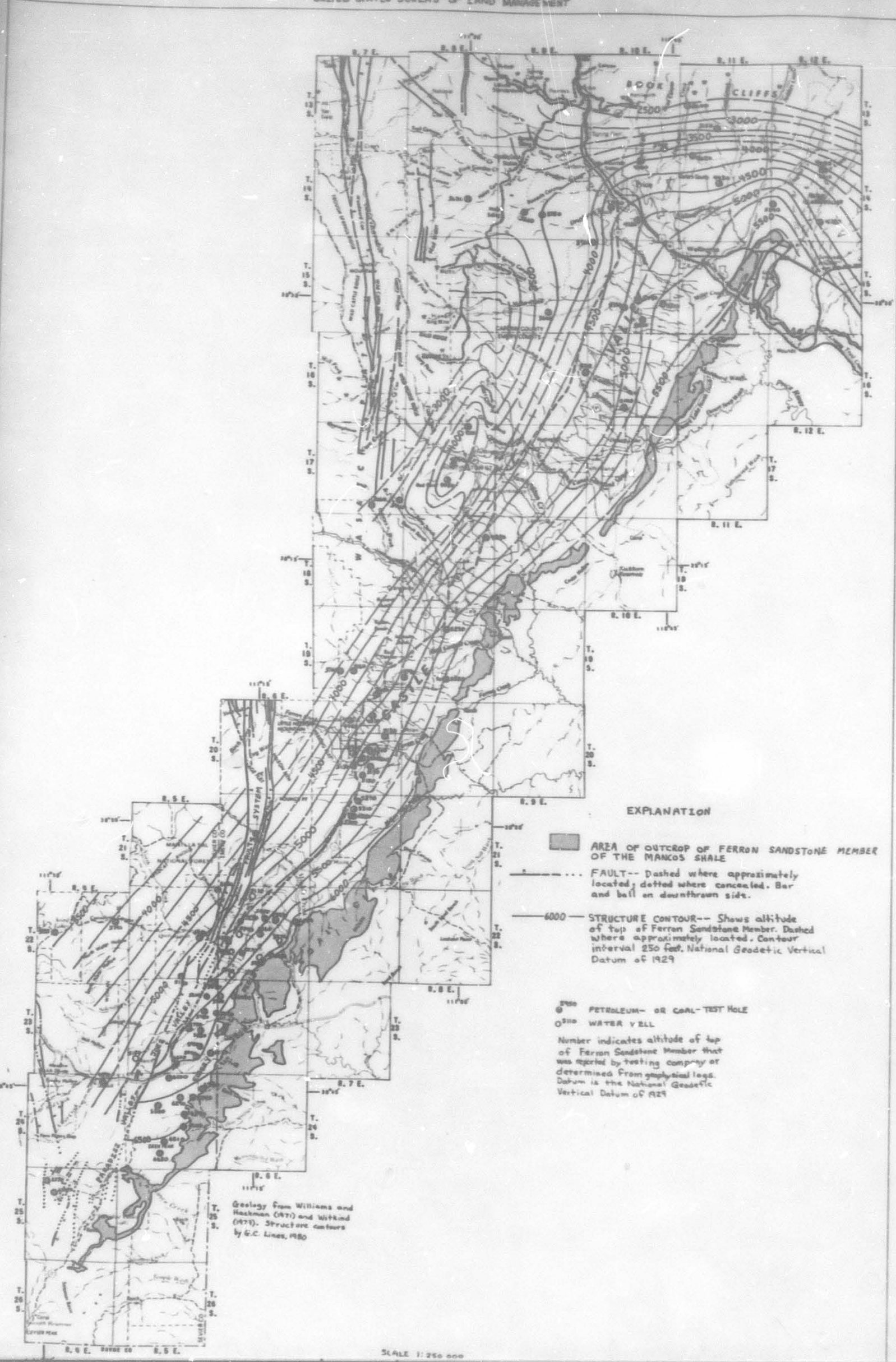




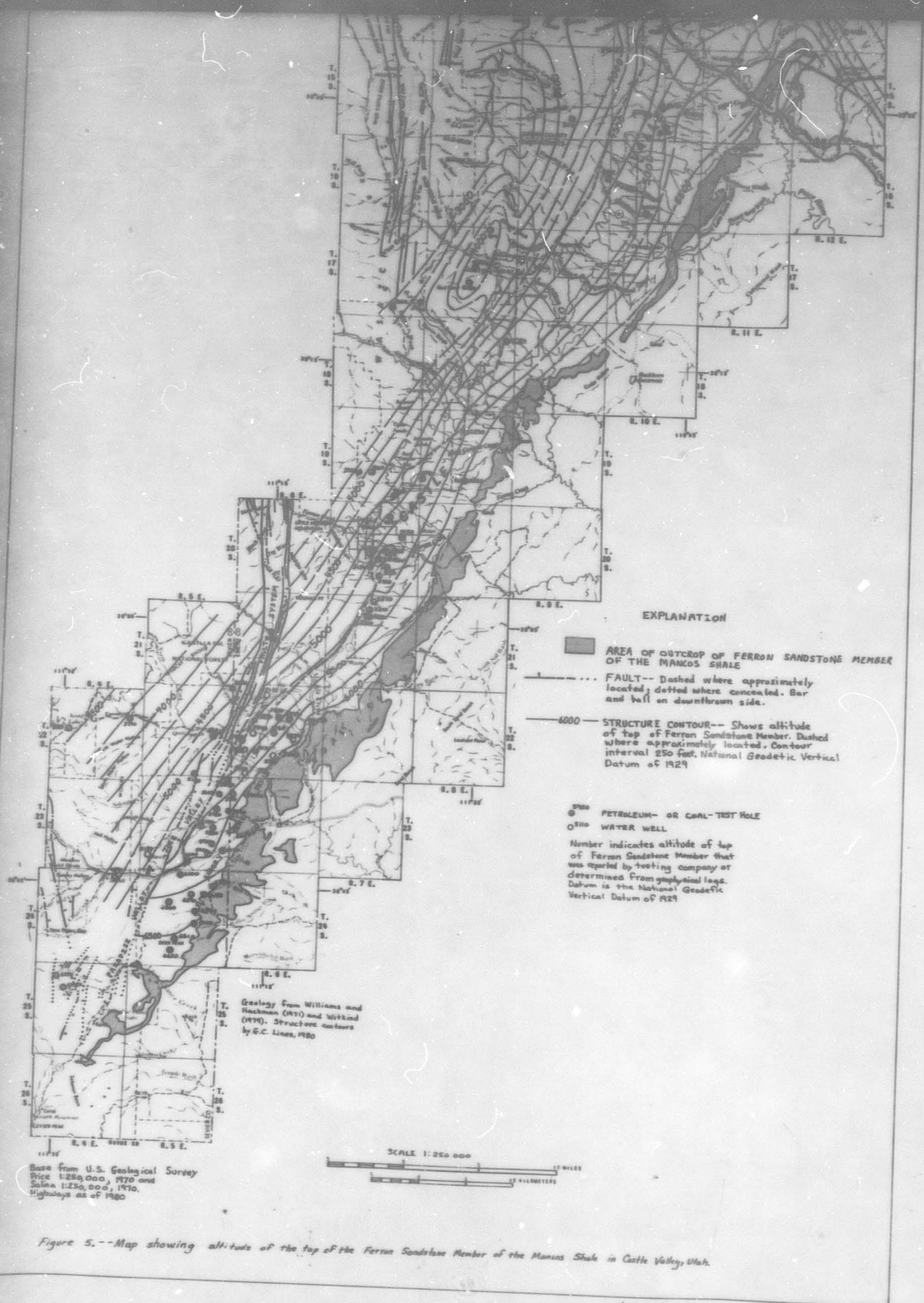




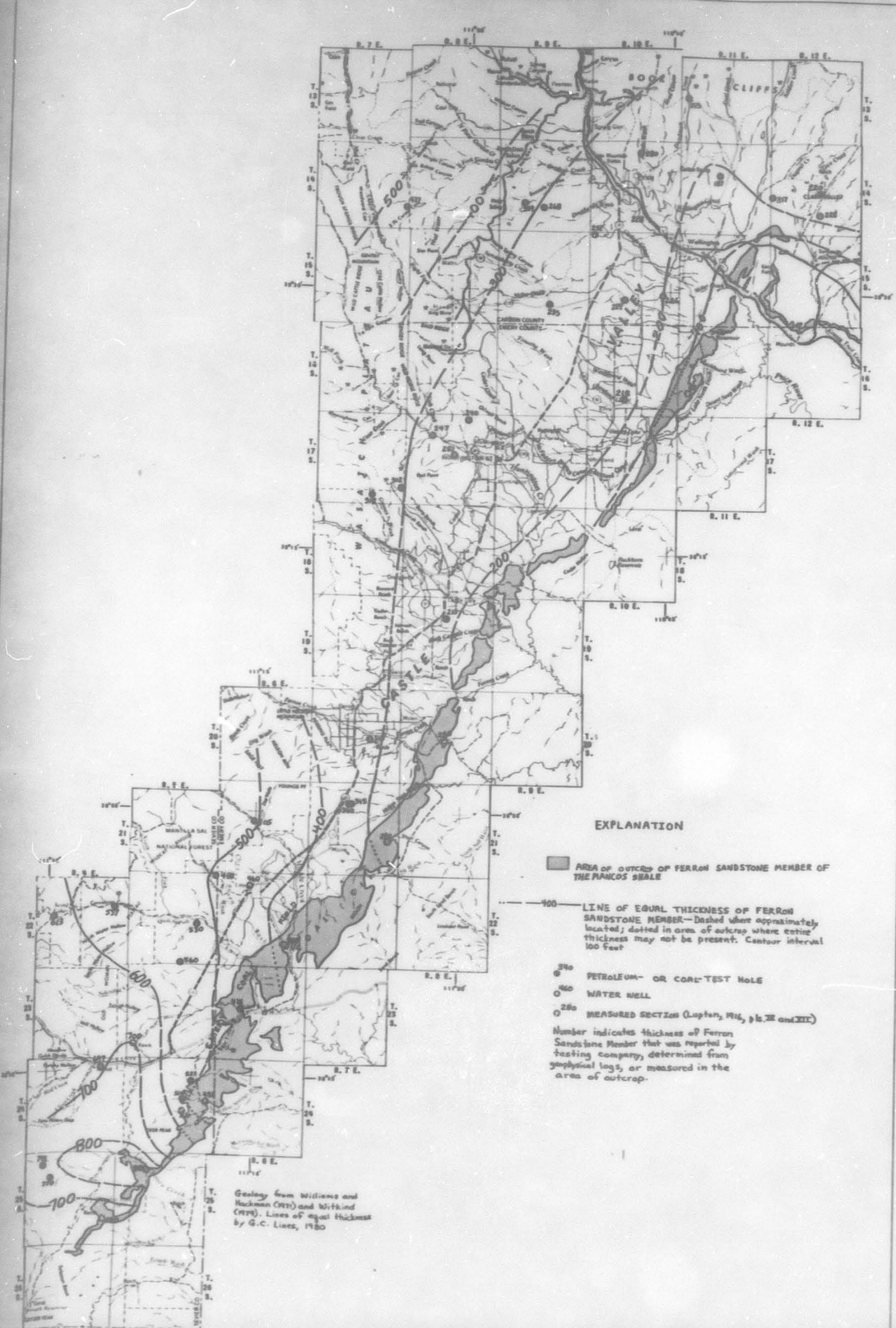




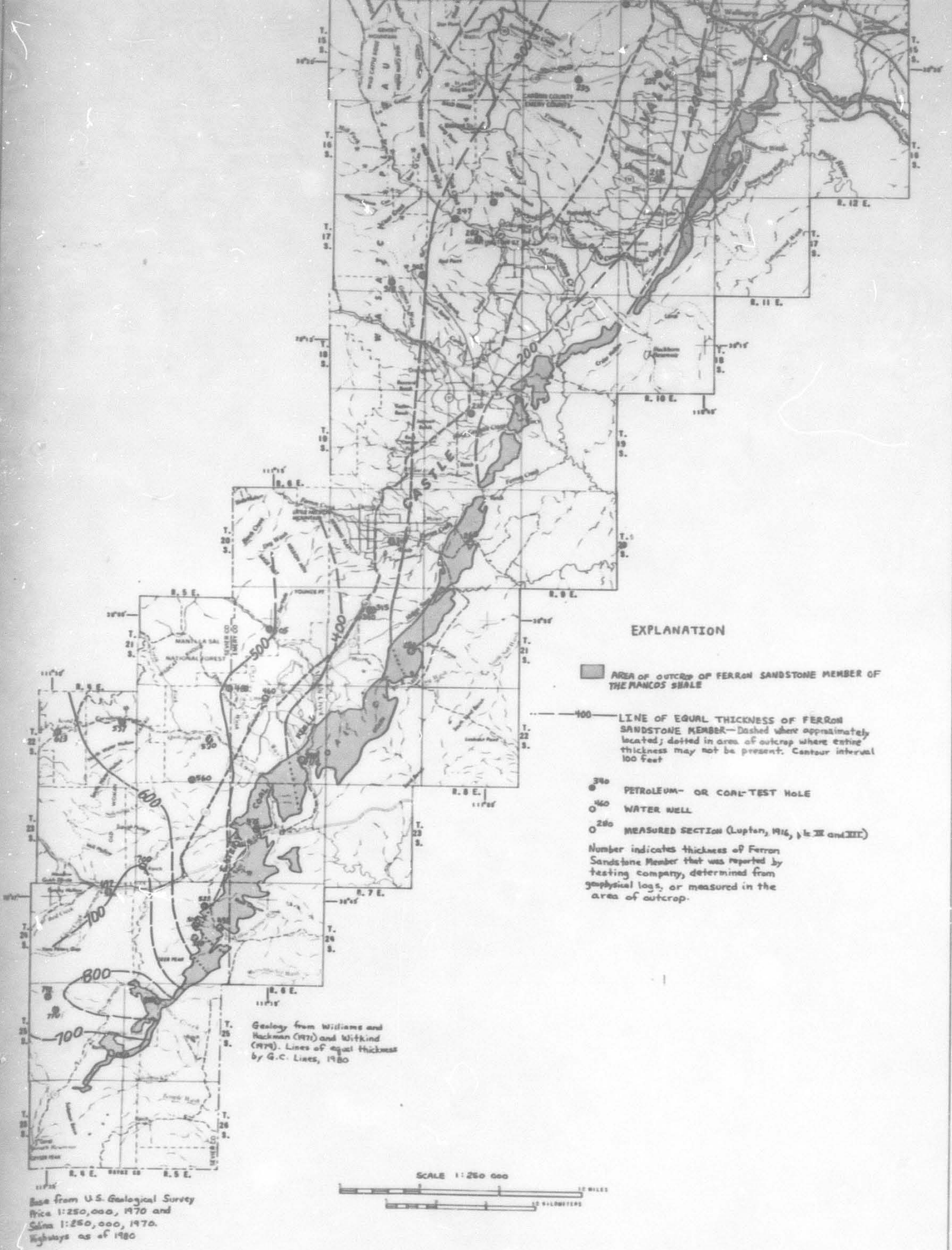

